\title{
BACTÉRIAS ENDOFÍTICAS DE MILHO (Zea mays L.) E SUA VARIABILIDADE GENÉTICA ANALISADA POR RAPD
}

\author{
ALEXANDRE OLIVEIRA DE SOUZA \\ Biólogo
}

Orientador: Prof. Dr. João Lúcio de Azevedo

Dissertação apresentada à Escola Superior de Agricultura "Luiz de Queiroz", da Universidade de São Paulo, para obtenção do título de Mestre em Agronomia, Área de Concentração: Genética e Melhoramento de Plantas.

PIRACICABA

Estado de São Paulo - Brasil

Março - 1996 
Dados Internacionais de Catalogação na Publicação (CIP)

DIVISĀO DE BIBLIOTECA E DOCUMENTAÇĀO - Campus “Luiz de Queiroz"/USP

Souza, Alexandre Oliveira

Bactéria endofiticas de milho (Zea mays L.) e sua variabilidade genética analisada por

RAPD / Alexandre Oliveira de Souza. - - Piracicaba, 1996.

83p. : il.

Dissertação (mestrado) - - Escola Superior de Agricultura Luiz de Queiroz, 1996.

Bibliografia.

1. Bactéria endófita em milho - Variação genética - Análise 2.Marcador molecular 3. Milho - Bacteriologia 4. Relação planta - bactéria I. Titulo.

CDD 633.15

589.9015 


\section{BACTÉRIAS ENDOFÍTICAS DE MILHO (Zea mays L.) E SUA VARIABILIDADE GENÉTICA ANALISADA POR RAPD}

\section{ALEXANDRE OLIVEIRA DE SOUZA}

Aprovada em: 26/04/1996

Comissão julgadora:

Prof. Dr. João Lúcio de Azevedo ESALQ/USP

Prof. Dra . Maria Helena P. Fungaro

Prof. Dr. Cláudio Costa

Depto. Biologia geral/UEL

UNESP/Botucatu

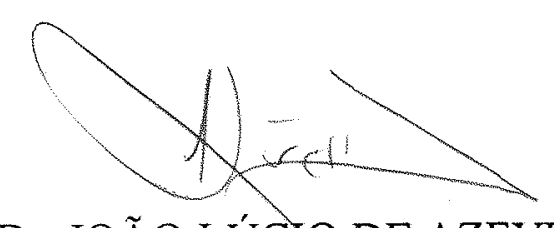

Prof. Dr. JOÃO LÚClO DE AZEVEDO Orientador 
Ofereço aos meus pais Sebastião de Souza e Maria do Carmo O. de Souza e dedico aos meus irmãos Denize, Sérgio e Mônica.

“... a ciência objetiva da biologia ... tem sido muitas vezes estendida para o reino subjetivo da ética e, ilegitimamente utilizada como justificativa tanto para políticas perniciosas quanto humanitárias nos campos social e cientifico."

(Douglas J. Futuyma) 


\section{AGRADECIMENTOS}

Agradeço a Deus, pela presença divina em todos os momentos de minha vida, e pela força espiritual a mim desiginada, para que pudesse concluir mais essa etapa rumo ao conhecimento científico.

Meu reconhecimento:

À Escola Superior de Agricultura "Luiz de Queiroz" da Universidade de São Paulo e ao Departamento de Genética, pela oportunidade de realização do Curso e ao Prof. Dr. João Lúcio de Azevedo pelo apoio e incentivo, pela amizade e orientação durante o curso.

À Fundação Tropical de Pesquisas e Tecnologia "André Tosello", na pessoa do Dr. Wanderlei P. Canhos, pelo apoio e por ter cedido suas instalações para execução de parte deste trabalho.

Ao Conselho Nacional de Desenvolvimento Científico e Tecnológico pela concessão de bolsa de estudo e à Fundação de Amparo a Pesquisa do Estado de São Paulo por concessão de auxílio financeiro ao projeto do atual trabalho.

A meus pais, Maria do Carmo O. Souza e Sebastião de Souza, por todo o carinho, incentivo e ajuda, todo o tempo e a meus irmãos Mônica Cristina, Denize e Sérgio, e a João Vittori (in memorian) e Christovolina Ribeiro de Souza, por toda ajuda e incentivo.

Ao Prof. Dr. Claudio Lopes de Souza Junior, pela concessão das linhagens de milho utilizadas neste trabalho, e pelas sugestões.

À Dra. Norma Gouvea Rumjaneck, pela orientação em minha iniciação científica e amizade, e à Profa. Dra. Elza Machado Menezes, pelo aconselhamento e sobretudo amizade. 
À Profa. Dra. Janete Magali de Araújo, pela amizade e valiosas sugestões para execução deste trabalho.

À Profa. Dra. Aline Pizzirani-Kleiner pelo apoio e incentivo durante o curso.

À amiga Márcia Pinhatti, pela orientação nos métodos de identificação dos microrganismos e pela grande amizade.

Ao Prof. Dr. José Odair Pereira, pelas valiosas sugestões ao presente trabalho.

Aos irmãos João Alencar Pamphile e André Bispo pela amizade, ajuda e companheirismo durante todos os momentos de nossa convivência. Aos amigos Maria Inês, André Lima, Welington Araújo, Chirlei Glienke, Margarete Nadalini, Carmem Rocha, Adriana Longo, Carlos Vildoso, Rosemeire Bueno, Iara Fino, Luciana Ribeiro e Marisa V.de Queiroz.

Aos Professores e colegas do Curso que contribuíram para a minha formação acadêmica, especialmente a Nilce e Luciano Nass, pela amizade e incentivo; Ana Fioravante, pela amizade e auxílio na análise estatística.

Aos colegas Antônio Carlos (Carlão), José A. da Silva (Zezo), às bibliotecárias Silvana e Aparecida Elizabeth, às secretárias Léia e Carmem, aos funcionários de campo Juscelino e Alfredo, e demais funcionários do Depto. de Genética da ESALQ, pela amizade e incentivos recebidos durante o curso.

E a todos que, direta ou indiretamente, contribuíram para a realização deste trabalho.

Muito Obrigado. 


\title{
BACTÉRIAS ENDOFÍTICAS DE MILHO (Zea mays L.) E SUA VARIABILIDADE GENÉTICA ANALISADA POR RAPD
}

\author{
Autor: ALEXANDRE OLIVEIRA DE SOUZA \\ Orientador: PROF. DR. JOÃO LÚCIO DE AZEVEDO
}

\section{RESUMO}

Foram isoladas 169 colônias de bactérias endofiticas de folhas de diferentes genotipos de plantas de milho sadias, pertencentes às populações BR105, BR-106 e população de híbridos simples entre essas, em duas localidades e coletas distintas. Trinta isolados foram identificados por meio de testes morfológicos e bioquímicos clássicos, definindo-se a ocorrência e percentagem relativa dos gêneros: Bacillus (55\%), Corynebacterium (15\%), Micrococcus (12\%), Listeria (9\%), Pseudomonas (6\%) e Erwinia (3\%). A técnica de RAPD foi aplicada a treze isolados do gênero Bacillus, o mais ocorrente, para medir o grau de similaridade genética entre esses e linhagens de referência, não endofíticas de Bacillus megaterium e Bacillus subtilis, e relacionar a origem dos isolados com o local de coleta e número da coleta. A análise de RAPD permitiu a diferenciação de quatro grupos entre Bacillus sp. endofiticos e as linhagens de referência, com aproximadamente $32 \%$ de similaridade entre si. Revelou-se grande variabilidade dentro do grupo, havendo relação dentro de dois grupos com o local de coleta e o número de coleta. Foi realizado um ensaio in vitro de antagonismo fungo-bactéria endofitica, entre dez isolados de bactérias, sendo os principais gêneros testados Bacillus e Micrococcus, e os fungos endofiticos Penicillium purpurogenum, $P$. spinulosum e Fusarium moniliforme, todos isolados de milho, e duas linhagens produtoras de antibióticos, não endofíticas de $P$. chrysogenum IFO 4626 e $1 Z 1671$. Este ensaio revelou não haver inibição do crescimento das bactérias pelos fungos endofíticos. Entretanto dois isolados endofiticos foram inibidos pelas linhagens de P. chrysogenum, indicando um tipo de associação diferente da que ocorreu entre os endófitos, caracterizada por uma antibiose. 


\section{MAIZE (Zea mays L.) ENDOPHYTIC BACTERIA AND THEIR GENETIC VARIABILITY ANALYSIS BY RAPD}

Author: ALEXANDRE OLIVEIRA DE SOUZA Adviser: PROF. DR. JOÃo LÚCIO DE AZEVEDO

\section{SUMMARY}

Endophytic bacteria were isolated in healthy maize leaves from different genotypes of BR-105 and BR-106 populations and from their simple hybrids population. Isolation was performed on two experimental areas by two distinct harvests. The total number of isolated bacteria colonies was 169 . Thirty isolates were identified by classic morphologic and biochemical tests, and defined the genus occurence and relative percentage: Bacillus (55\%), Corynebacterium (15\%), Micrococcus (12\%), Listeria (9\%), Pseudomonas (6\%) and Erwinia (3\%). RAPD technique was performed to measure the genetic similarities among the thirteen main occurring Bacillus endophytes, and the reference strains not endophytes Bacillus megaterium and Bacillus subtilis, also relating the endophyte origins with the harvest area and harvest number. RAPD analysis allowed to differentiate four groups among Bacillus endophytes and Bacillus reference strains, presenting nearly $32 \%$ of similarity themselves. High variability was detected within the group, being detected within two groups relationships with harvest area and harvest number. It was performed an in vitro endophyte bacteriafungi antagonism assay, with ten bacteria isolates, being the major genus assayed Bacillus and Micrococcus, and the endophytes Penicillium purpurogenum, $P$. spinulosum and Fusarium moniliforme, all of them isolated from maize, and two antibiotic producers, not endophytes, $P$. chrysogenum IFO4626 and IZ1671. Such assay has shown that endophytic fungi was not able to inhibit endophytic bacteria growth. Althoug, two endophytes were inhibited by antibiotic producers lineages $P$. chrysogenum, indicating a different kind of association from that occuring among endophytes, characterized by antibiosis. 


\section{SUMÁRIO}

RESUMO

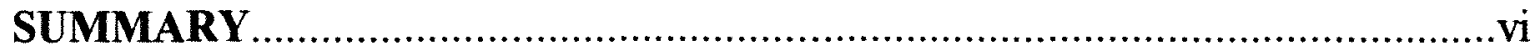

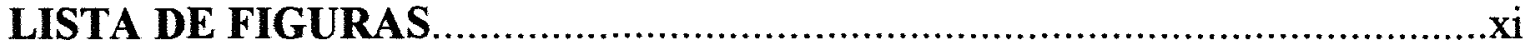

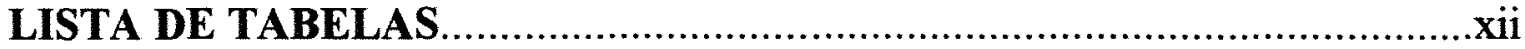

1. INTRODUÇÃ

2. REVISÃO DE LITERATURA

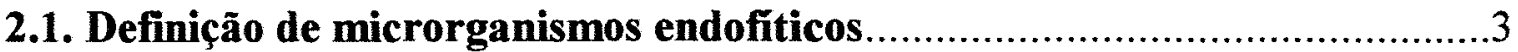

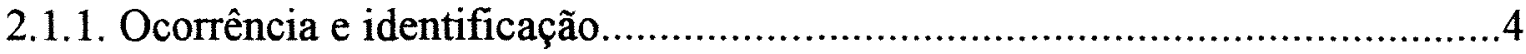

2.1.2. Relação planta-endófito: aspectos ecológicos e da fixação

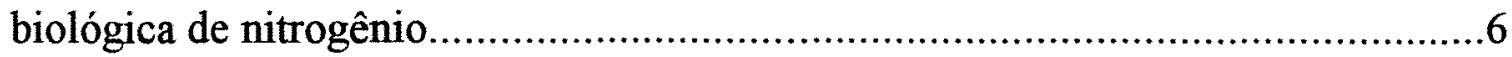

2.2. Aplicações biotecnológicas dos endofíticos..............................................10

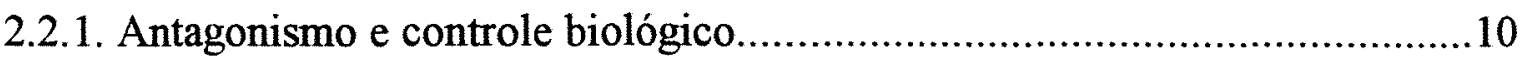

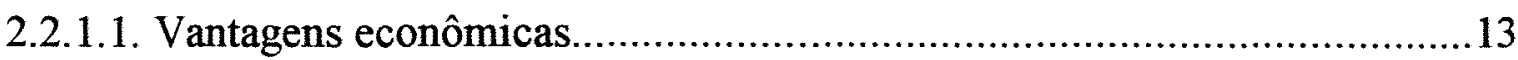

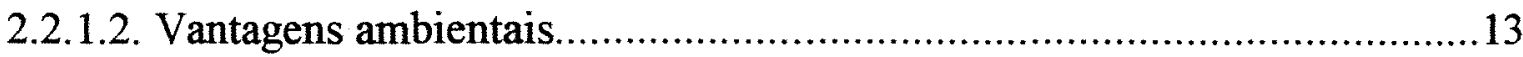

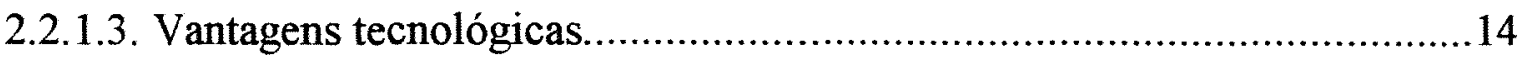

2.2.2. Vetores/hospedeiros para transformação genética de plantas.....................14

2.3. RAPD (Random Amplified Polymorfic DNA) .......................................16

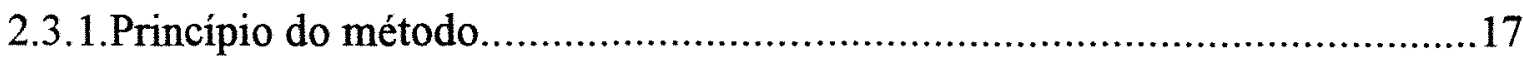

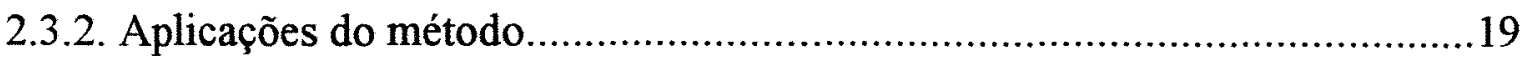

2.3.3. Utilização do RAPD em estudos relacionados a bactérias..........................20

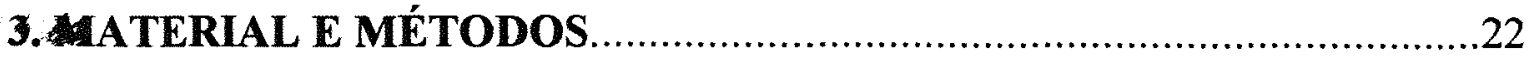

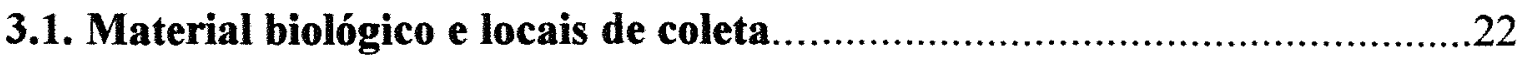

3.1.1. Linhagens de milho utilizadas para isolamento de bactérias.....................22

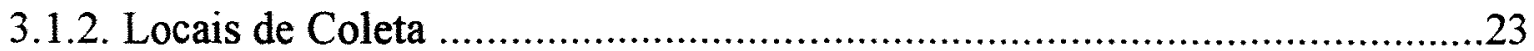

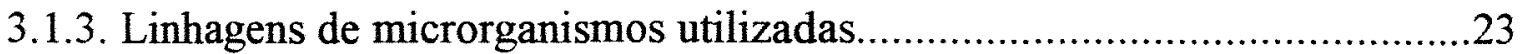

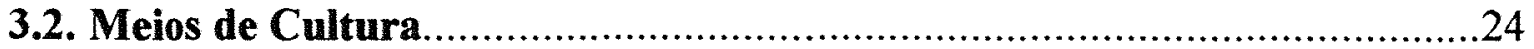

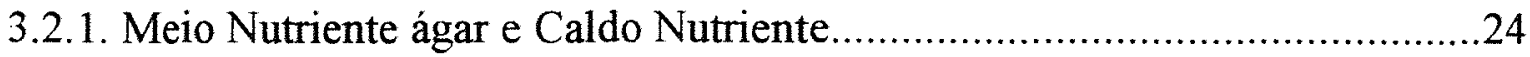




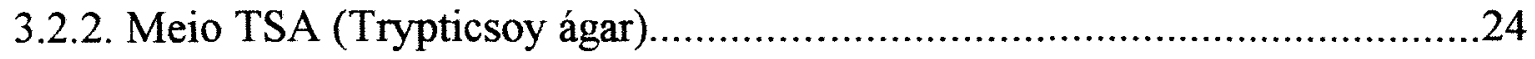

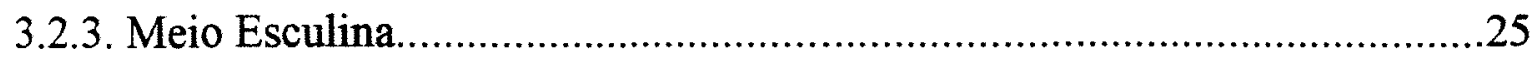

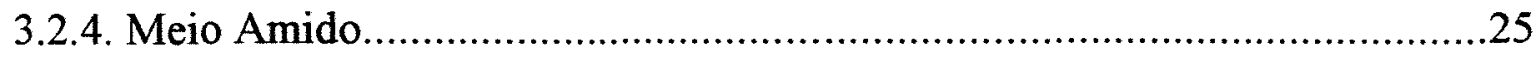

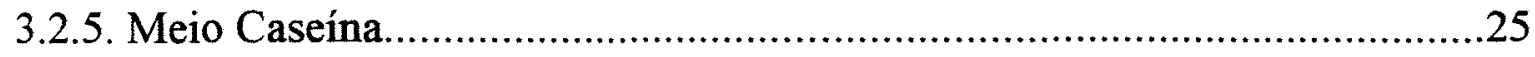

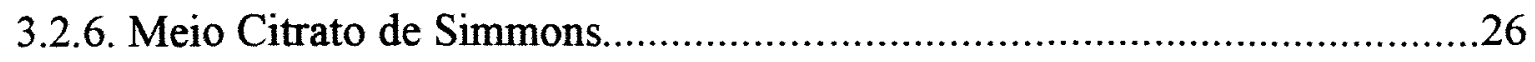

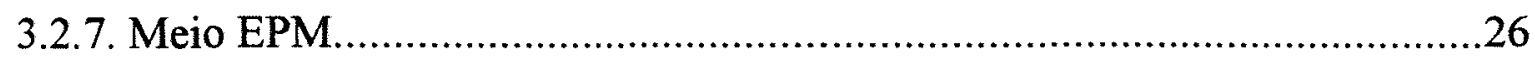

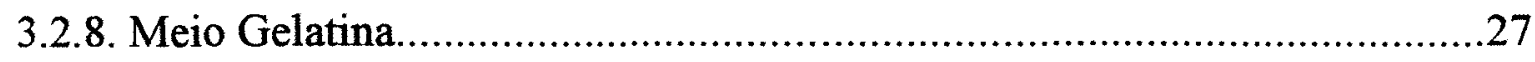

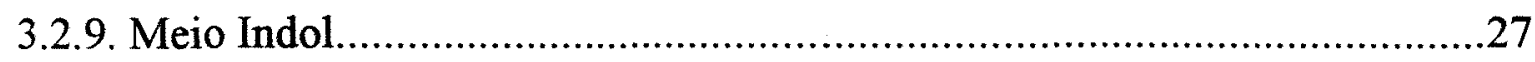

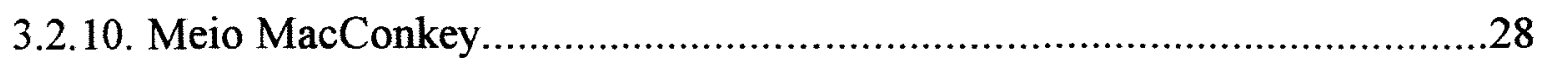

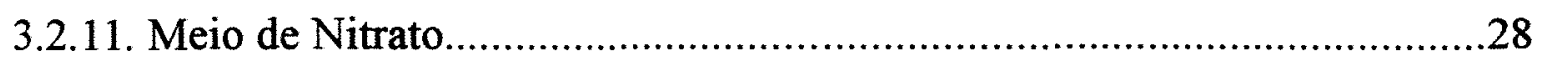

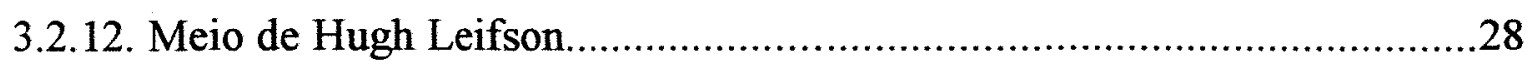

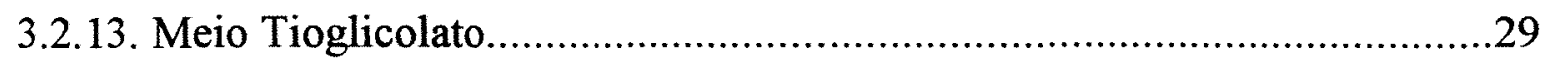

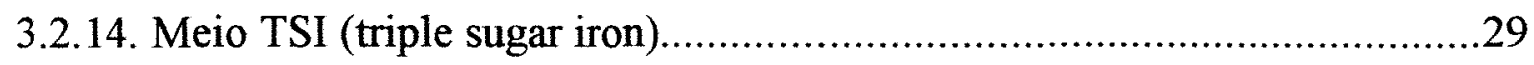

3.2.15. Meio Voges Proskauer e Vermelho de Metila..........................................30

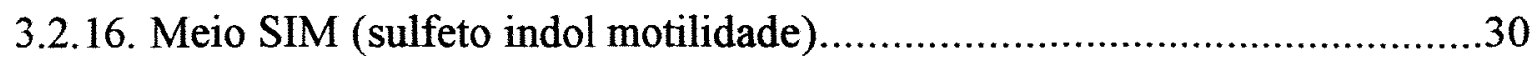

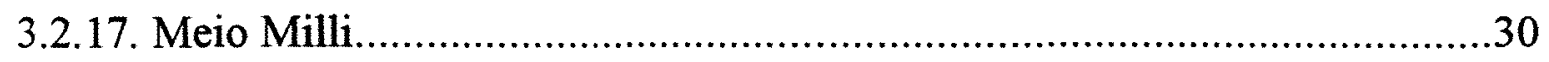

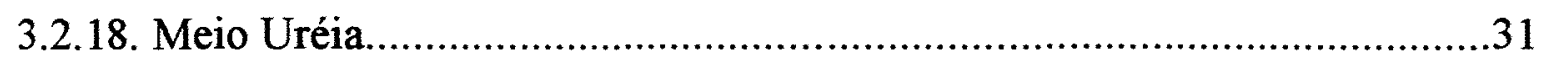

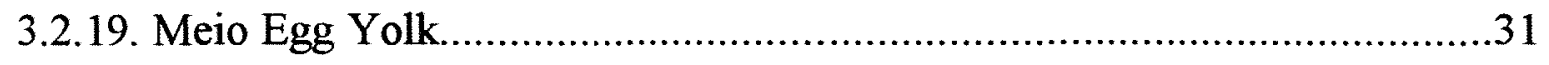

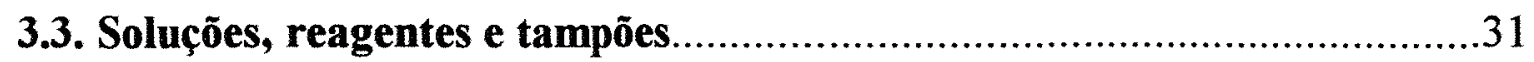

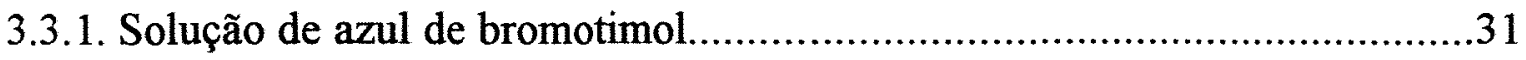

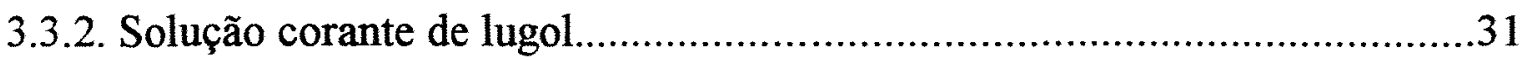

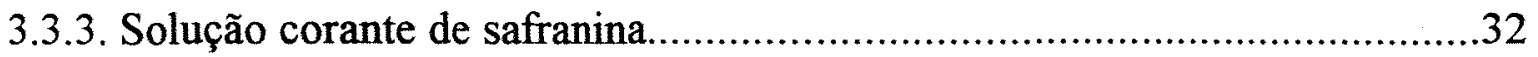

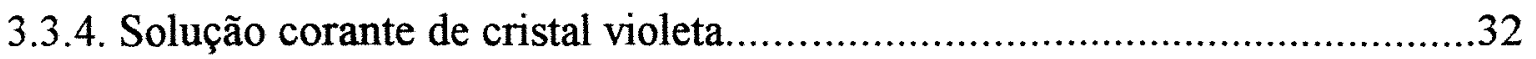

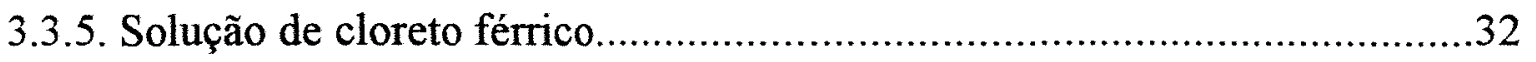

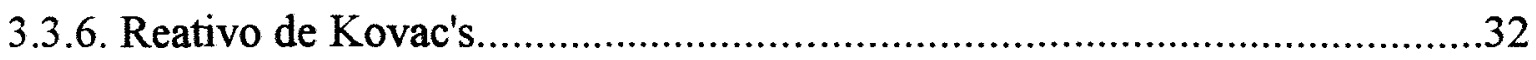

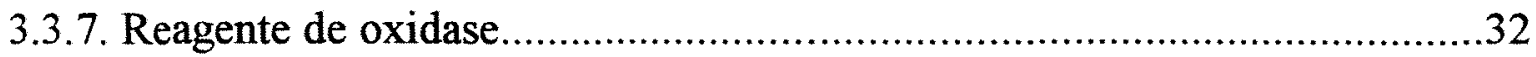

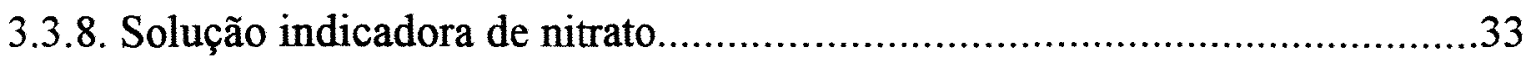

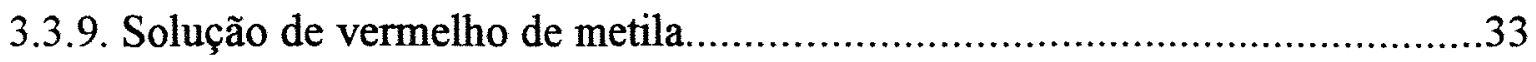

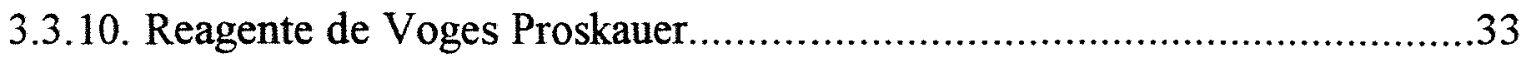

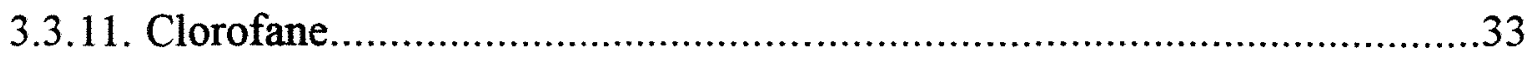

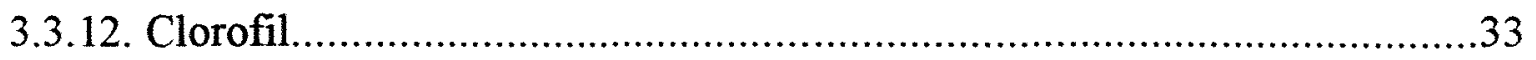

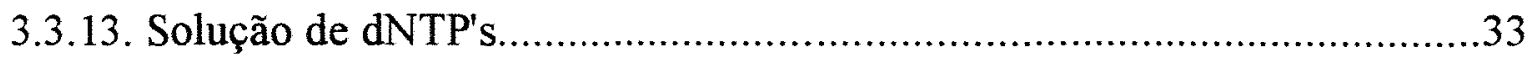

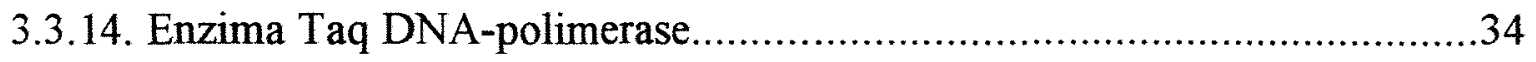

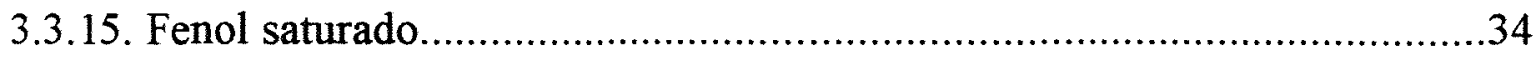

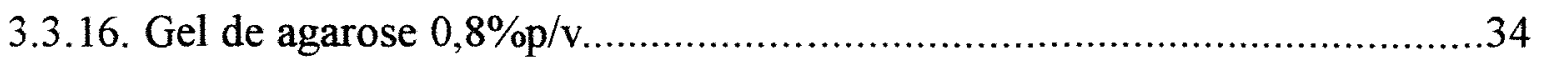

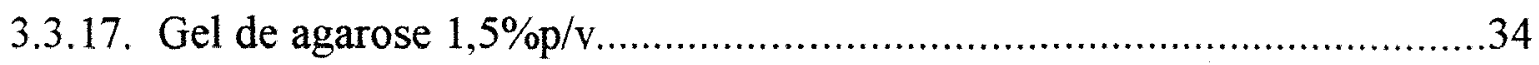




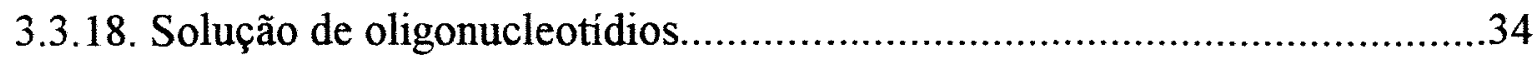

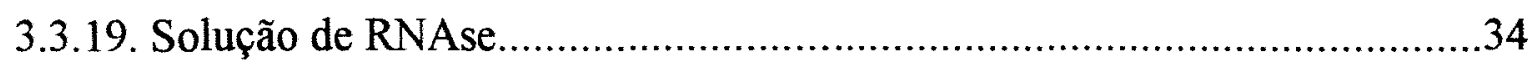

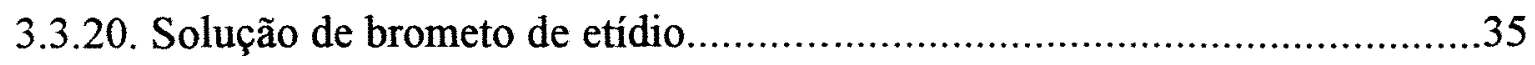

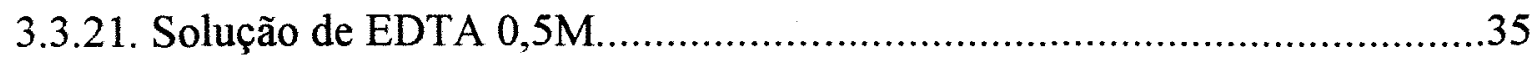

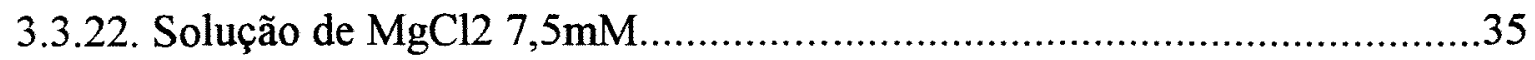

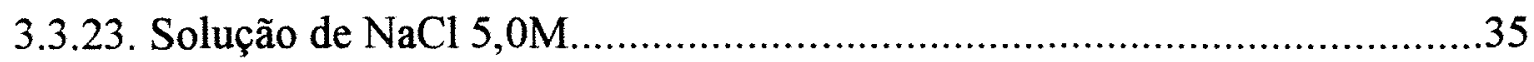

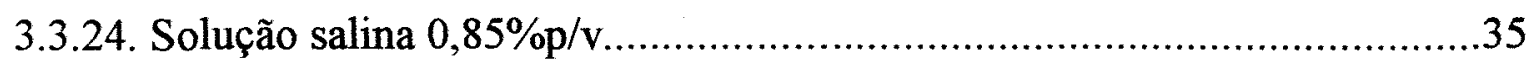

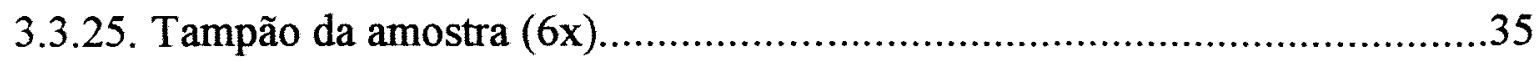

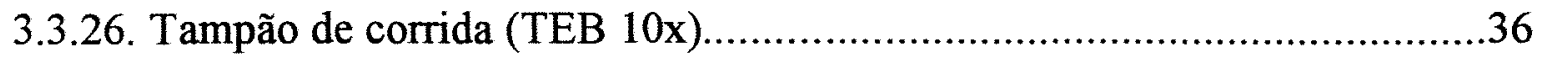

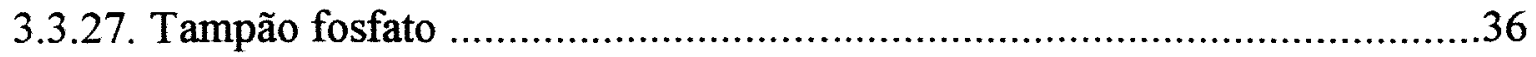

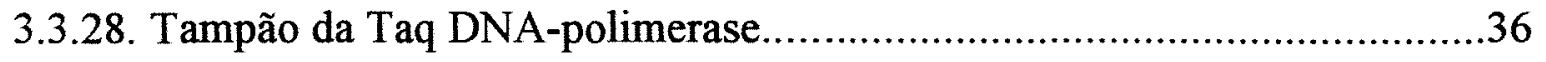

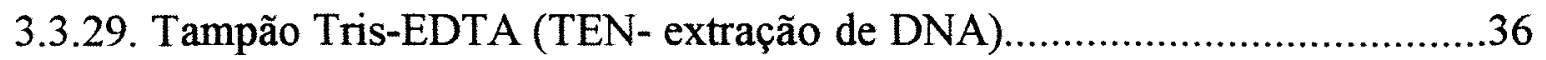

3.4. Caracterização das culturas de bactérias isoladas.................................36

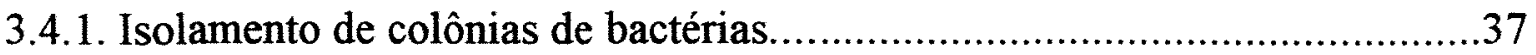

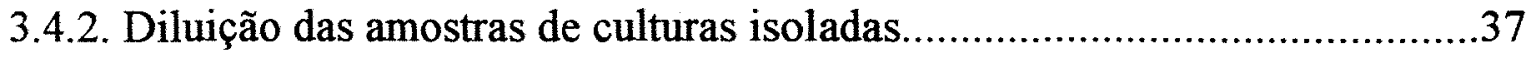

3.4.3. Purificação das colônias de bactérias isoladas ............................................37

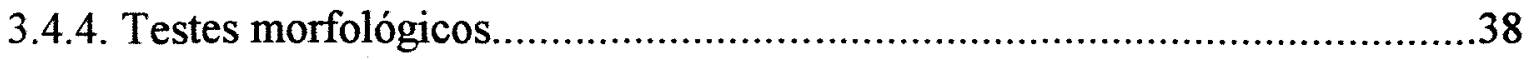

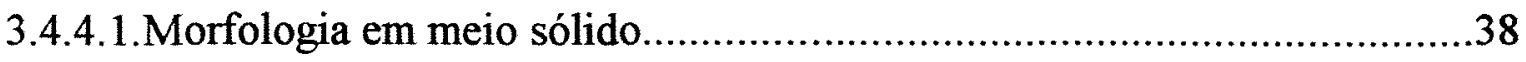

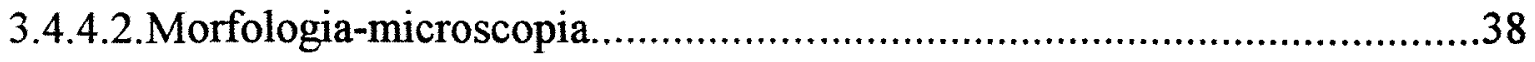

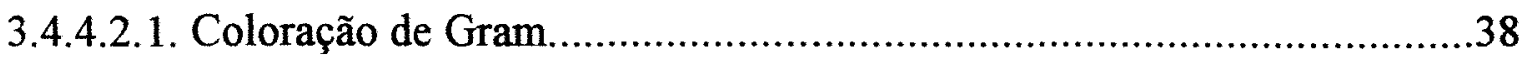

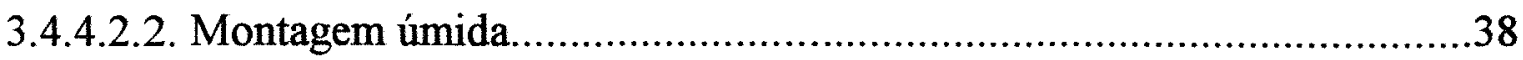

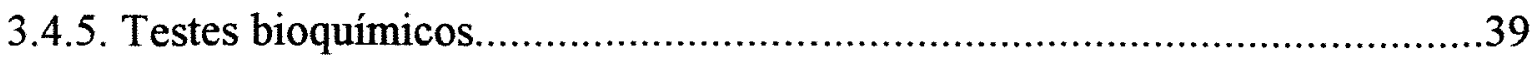

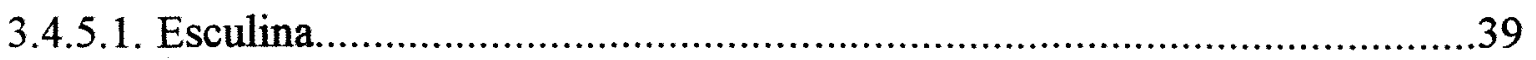

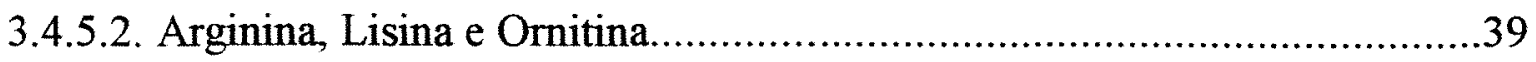

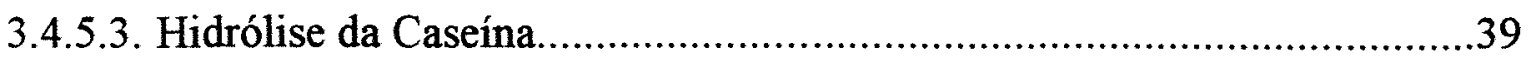

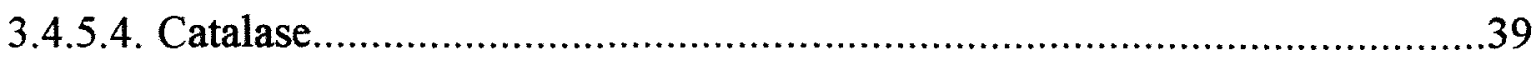

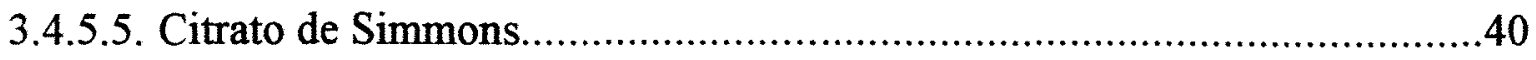

3.4.5.6. EPM

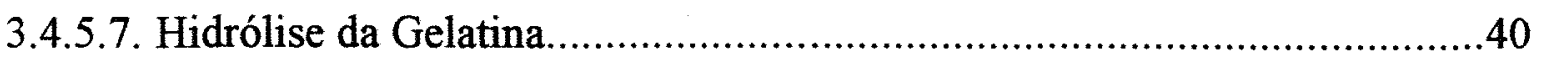

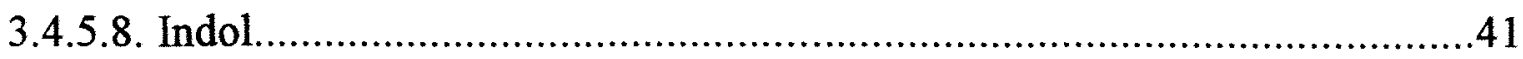

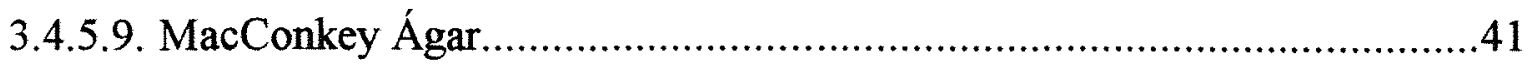

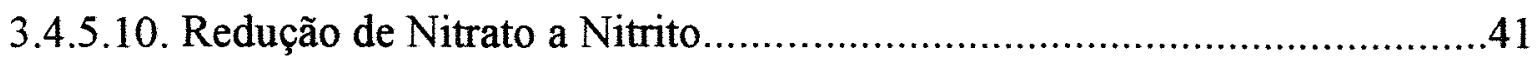

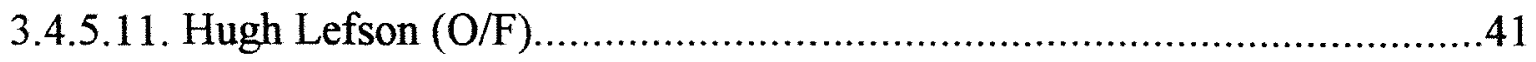

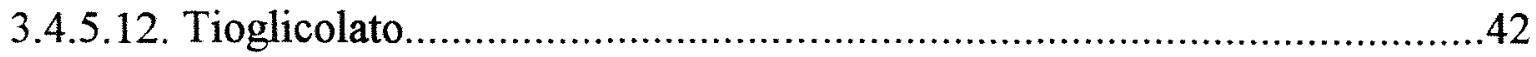

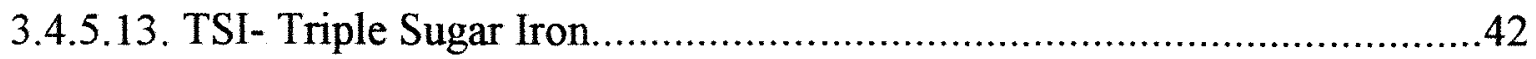

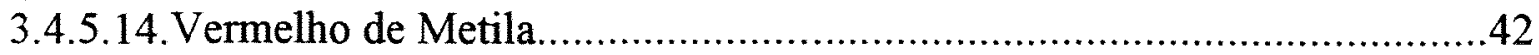




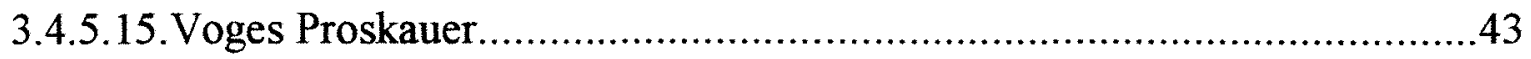

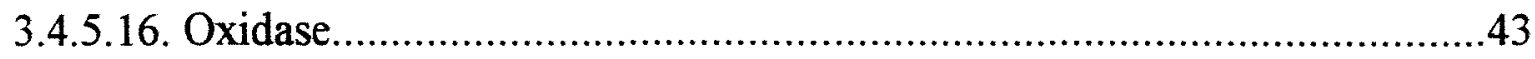

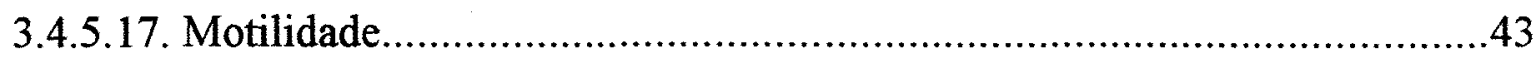

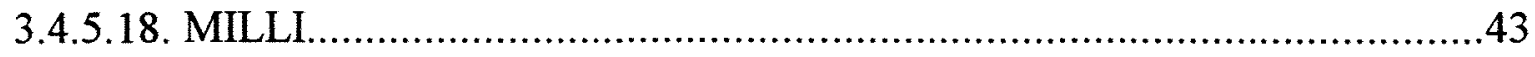

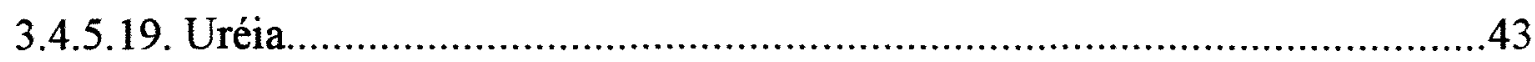

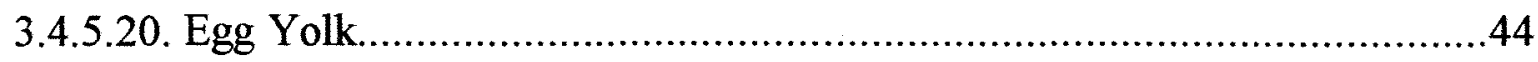

3.5. Teste antagonístico: fungos versus bactérias endofíticas.........................44

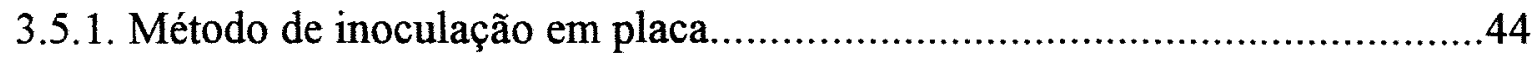

3.6. Análise da variabilidade genética dos isolados por RAPD .....................44

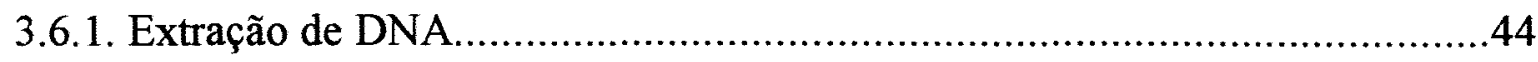

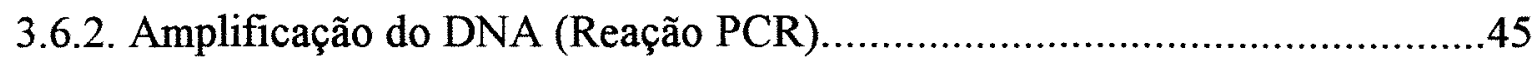

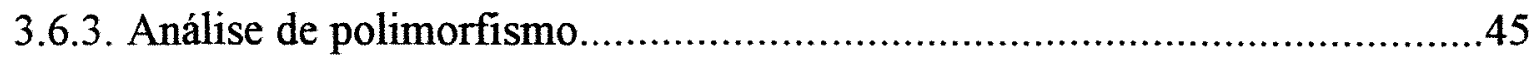

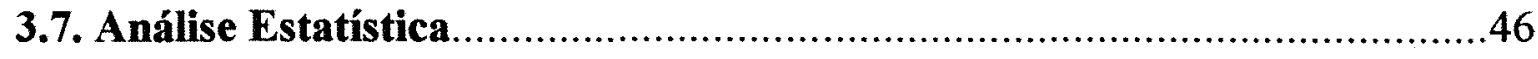

4. RESULTADOS E DISCUSSÃO ........................................................48

4.1. Isolamento e frequência de infecção das plantas de milho.............................48

4.2. Identificação dos isolados bacterianos..................................................58

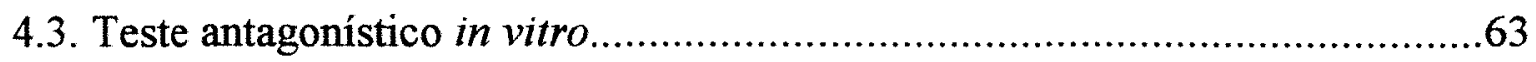

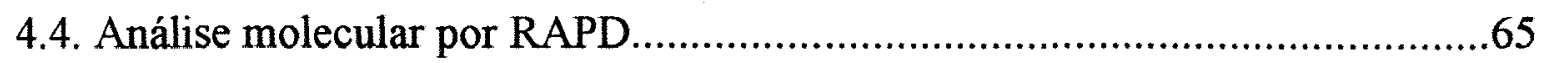

4.4.1. Padronização da técnica e seleção de primers..........................................65

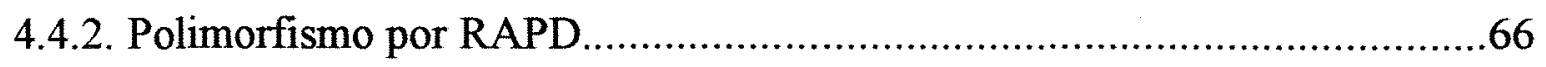

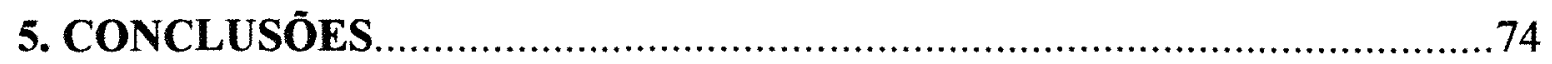

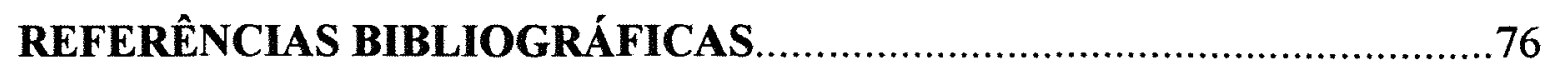




\section{LISTA DE FIGURAS}

Página

4.1. Aspectos do isolamento de bactérias endofiticas de milho (Zea mays L.).

4.2. Gráfico representativo das percentagens relativas de bactérias endofiticas em três populações de milho, em duas coletas, em dois locais.

4.3. Gráfico representativo das percentagens relativas de bactérias endofíticas, em dois locais, três populações de milho. Considerando -se juntas as duas coletas.

4.4. Gráfico representativo das percentagens relativas de colônias de bactérias endofiticas em milho no Local 1, Coletas 1 e 2, nas populações $\mathrm{P} 1, \mathrm{P} 2$ e P1x2

4.5. Gráfico representativo das percentagens relativas de colônias de bactérias endofiticas em milho no Local 2, Coletas 1 e 2, nas populações $\mathrm{P} 1, \mathrm{P} 2$ e P1x2. .56

4.6. Gráfico representativo das percentagens relativas de ocorrência de bactérias endofiticas em milho, coletas 1 e 2 , populações de milho $\mathrm{P} 1, \mathrm{P} 2$ e P1x2. Considerando-se juntos os dois locais.

4.7. Distribuição em percentagem de gêneros de bactérias endofíticas isoladas de folhas de plantas de milho (Zea mays $\mathrm{L}$ ).

4.8. Padrão de seleção de primers em linhagens endofíticas de Bacillus sp. isolados de folhas de milho. "Primers " OPE (1 a 15) e OPX $(03,04,07,11)$......68 
4.9. Padrão representativo de bandas obtidas por amplificação com o "primer" OPE14, em linhagens endofiticas de Bacillus sp. isolados de folhas de milho.

4.10. Matriz de similaridade obtida a partir do coeficiente de Jaccard, para os isolados endofíticos de Bacillus sp. isolados de folhas de milho.

4.11. Dendrograma usando "UPGMA algoritmo" para agrupar os treze isolados de Bacillus endofiticos e as duas espécies de Bacillus megaterium (3026) e Bacillus subtilis (2471), com base em seus índices de similaridade.

\section{LISTA DE TABELAS}

3.1. Relação dos genótipos homozigotos puros e híbridos simples retirados ao acaso das populações $\mathrm{P} 1, \mathrm{P} 2$ e P1x2, empregados nos experimentos

3.6.1. Sequência de nucleotídios no sentido 5'-3', e conteúdo CG dos cinco oligonucleotídios selecionados e utilizados para amplificação.

4.1. Número de colônias de bactérias endofíticas isoladas de folhas de plantas milho em três populações.

4.2. Médias do número de colônias para cada tratamento, considerando-se três repetições, no Local 1 (Areião). .50

4.3. Médias do número de colônias para cada tratamento, considerando-se três repetições, no Local 2 (Caterpillar).

4.4. (A, B, C, D e E). Análise de "deviance" da ocorrência de bactérias endofiticas em folhas de milho (Zea mays L.), nas populações

$\mathrm{P} 1, \mathrm{P} 2$ e P1x2 
4.5. Identificação dos isolados de bactérias endofiticas de milho quanto ao gênero.

4.6. Características e reações aos testes bioquímicos utilizados na identificação dos gêneros de bactérias endofiticas de folhas de milho.

4.7. Características morfológicas utilizadas na identificação dos gêneros de bactérias endofiticas de folhas de milho. 62

4.8. Crescimento in vitro de isolados de bactérias endofiticas de milho, em associação com linhagens de fungos endofíticos Penicillium spinulosum, P. purpurogenum, Fusarium moniliforme, e não-endofiticos e produtores de penicilina: $P$. chrysogenum .64

4.9. Dados referentes ao código dos isolados utilizados no ensaio de RAPD, e seus respectivos locais de coleta, número da coleta e população de milho hosapedeira. 


\section{INTRODUÇÃO}

Endófitos são microrganismos isolados do interior dos tecidos ou órgãos vegetais. Vários microrganismos, durante todo o seu ciclo de vida, ou somente parte dele, vivem no interior dos vegetais. Usualmente, esses microrganismos vivem em uma associação que embora possa ser antagônica, muitas vezes é neutra ou benéfica para o hospedeiro. A natureza dessas associações é diversa e via de regra exibe vários graus de interdependência fisiológica e ecológica.

Alguns gêneros de bactérias endofíticas de cebola tem sido isolados $\mathrm{e}$ reinoculados para testar a sua patogenicidade em bulbos de plantas sadias, verificando-se que estes isolados podem se tornar patógenos oportunistas quando ocorrem alterações na fisiologia do hospedeiro devido a altas temperaturas durante a maturidade dos bulbos. Outros estudos sobre bactérias endofiticas abordando isolamento, análise de densidade populacional e distribuição em diferentes tecidos da planta têm sido publicados e vêm se intensificando nos últimos anos. Entretanto, muitas pesquisas ainda deverão ser feitas a respeito de aspectos ecológicos, genéticos e fisiológicos dessa interação bactéria-planta.

Recentemente, também na área de fixação biológica de nitrogênio, alguns trabalhos têm indicado a importância do estudo dos endofiticos. Muitas das novas bactérias fixadoras de $\mathrm{N}_{2}$, tais como Acetobacter diazotrophicus ou Herbaspirillum sp., isoladas de culturas diversas, não foram isoladas do solo e portanto podem ser consideradas endófitos de plantas, ou ainda, patógenos moderados de plantas. A infecção da cana-de-açúcar, batata-doce ou sorgo com tais bactérias tem se mostrado dependente de fungos micorrízicos vesículo arbusculares. Isto demonstra um tipo de associação completamente nova entre bactérias endofíticas, fixadoras de $\mathrm{N}_{2}$ e gramineas, o que contrasta com o conceito de associações rizosféricas conhecidas até o momento. Obviamente as bactérias que vivem dentro dos tecidos vegetais, especialmente em plantas ricas em açúcares podem beneficiar mais as plantas, que as bactérias da rizosfera, as quais competem por nutrientes com toda a microflora do solo. Logo, esses resultados abrem novos caminhos para a abordagem e expansão da fixação de nitrogênio em cereais e gramíneas. Além disso, sugerem que tal possibilidade tem sido demonstrada em estudos de balanço de ${ }^{15} \mathrm{~N}$ e $\mathrm{N}$, em cana-deaçúcar, na EMBRAPA/CNPAB, onde mais de $150 \mathrm{Kg} \mathrm{N}^{-h^{-1}}{ }^{-1}$ ano-1 foram obtidos da fixação de nitrogênio. 
Em síntese, a presença dos endofíticos é um fenômeno assintomático, não perceptivel para o observador que, para estudá-los precisa isolá-los, a partir dos tecidos vegetais, aparentemente sadios, e cultivá-los em laboratório.

Este trabalho teve por objetivo, o estudo de bactérias endofiticas em plantas de milho (Zea mays), importante gramínea utilizada como fonte de proteínas em todo o mundo tanto para a alimentação humana, como animal. Isolaram-se microrganismos de folhas de plantas sadias de milho em duas populações de milho BR-105 e BR106, assim como em uma população de híbridos simples obtidos por meio de cruzamentos entre essas duas populações. Foram realizadas duas coletas distintas, em dois diferentes locais, e procurou-se estudar a distribuição dos endofíticos nas três populações, medindo as variâncias entre os diferentes tratamentos considerados (coletas, locais de coleta, genótipos, populações). Numa segunda fase, procurou-se identificar alguns dos isolados referentes a um grupo representativo de características morfológicas; assim como analisar in vitro as interações antagonísticas entre alguns isolados de bactérias endofiticas e linhagens de fungos endofiticos isolados de raiz e sementes de plantas de milho, assim como com linhagens de fungos produtoras de antibiótico, não endofíticas. Procurou-se, ainda determinar similaridades e distâncias genéticas entre os isolados bacterianos mais freqüentes (gênero Bacillus), por meio do polimorfismo gerado pelos marcadores de RAPD.

De maneira geral, o conhecimento gerado pelo estudo da associação plantamicrorganismo, será certamente de enorme valor para o entendimento do papel que esses microrganismos desempenham no seu hospedeiro. E para um futuro próximo pode-se esperar inúmeros trabalhos visando o estudo da especificidade $\mathrm{e}$ estabelecimento do fenômeno, estudos sobre as funções regulatórias dos microrganismos endofíticos em seus hospedeiros, assim como estudos sobre o controle da interação planta-microrganismo, durante a fase endofítica ou nãopatogênica, como preferem alguns autores. Os microrganismos endofiticos numa análise final, se comportam como ótimo material biológico de interesse biotecnológico, posto que podem ser utilizados em programas de agricultura alternativa para incremento ou melhoria da produtividade vegetal, tais como vetores para introdução de genes de interesse econômico em importantes culturas, no controle biológico de pragas, como agentes antagônicos; ou ainda, como vêm sendo utilizados na diminuição dos gastos com insumos e fertilizantes nitrogenados em culturas como a soja, e mais recentemente a cana-de-açúcar, através da fixação biológica do nitrogênio atmosférico promovida em parte pelas bactérias endofiticas. 


\section{REVISÃO DE LITERATURA}

\subsection{Definição de microrganismos endofíticos}

De uma maneira geral, como exposto por Pereira (1993) a ocorrência de fungos em tecidos vegetais freqüentemente é definida por modificações características da planta, o mesmo sendo verdadeiro para as bactérias, onde sua presença pode causar danos como citados por Cother \& Dowling (1986) em cebola. Entretanto, a ocorrência de infecções assintomáticas em tecidos vegetais aparentemente sadios vem sendo registrada de forma muito intensa para tais microrganismos.

A definição do termo endofítico segundo Bary (1866), citado por Stone (1986) refere-se à flora micótica interna dos tecidos vegetais, em casos de infecções assintomáticas ou não e, nos casos de interações antagonísticas ou simbióticas. Carroll (1986) restringiu o uso do termo endofítico para organismos que causam colonizações assintomáticas, excluindo desse conceito fungos patogênicos e fungos mutualísticos tais como os fungos micorrízicos. Com o aumento de investigações na área e com a descoberta de diferentes aspectos de interações dos fungos com os seus hospedeiros, Petrini (1991) propôs que a definição de Carroll fosse ampliada incluindo todos os organismos que, habitando a parte aérea dos órgãos das plantas, fossem capazes de colonizar, em algum tempo de seu ciclo de vida, os tecidos internos dos vegetais, sem causar um dano aparente. O próprio Carroll (1988), refere-se ao termo, de modo mais genérico, como fungos que são encontrados mais no interior das plantas que nas suas superficies.

BARY, A. de. Morphologie und physiologie der Pilze. Flechten, und Myxomyceten. V II. Hofmeister's Handbook of Physiological Botany, Leipzig, 1866 


\subsubsection{Ocorrência e identificação}

Apesar da ocorrência de bactérias endofiticas em diferentes plantas, pouco se sabe sobre sua identidade, diversidade e níveis populacionais nos diferentes tecidos. As bactérias endofíticas provavelmente desenvolveram íntima relação com sua planta hospedeira através de processos coevolucionários e podem influenciar a fisiologia da planta de alguma forma ainda não elucidada (Misaghi \& Donndelinger, 1990).

Um dos trabalhos pioneiros no estudo das bactérias endofíticas foi realizado por Colombo (1978), no qual ele relatou a ocorrência de bactérias endofiticas no talo de algas, entre os sifões e dentro dos filamentos cenocíticos. Geralmente estão localizadas nos vacúolos, estando preferencialmente bem próximas aos cloroplastos. Este autor sugeriu a ocorrência de um equilíbrio fisiológico entre a bactéria e seu hospedeiro. Supondo ainda, que o fato dos endofíticos se encontrarem próximos aos cloroplastos e nas zonas mais jovens dos talos, indicaria uma ligação com a atividade fotossintética da alga e sua provável dependência de oxigênio.

Entretanto, a partir dos anos 80 , os trabalhos se tornaram mais frequentes, Becking (1984), identificou características morfológicas dos nódulos de raízes de Dryas e Rubus (ROSACEAE), descrevendo as estruturas do endófito Frankia, tais como estruturas semelhantes a esporos, por meio de micrografias eletrônicas de trasmissão.

Outros trabalhos abordando a forma de ocorrência dessas bacterias endofiticas, empregando métodos e técnicas mais aperfeiçodas de estudo e análise foram realizados, como o de Jacobs et al. (1985), onde os autores enumeraram, localizaram e caracterizaram bactérias endofíticas de raizes de beterraba açucareira utilizando técnicas imunológicas e microscopia eletrônica de varredura, e desta forma, verificando um aumento na população de bactérias nas regiões de emergência das raízes secundárias, em comparação com as regiões centrais e periféricas da raiz. Os autores sugeriram que essas regiões de maior ocorrência constituem uma rota de colonização das bactérias. Os mesmos ainda relataram a ocorrência de um grande número de diferentes espécies, dentre elas: Bacillus subtilis, Pseudomonas aeruginosa, Corynebacterium sp., e Erwinia herbicola. Este trabalho, também pioneiro na época, mais uma vez demonstrava a ocorrência de bactérias não patogênicas estabelecendo uma relação simbiótica intracelular em raiz de plantas de beterraba. 
Ainda dentro deste contexto, McInroy \& Kloepper (1991), verificaram que plantas sadias de milho e algodão contêm uma microflora bacteriana muito diversificada, sendo o número de gêneros endofíticos isolados dos tecidos do caule $\mathrm{e}$ da raiz maior que o encontrado na rizosfera dessas mesmas plantas. Como a população de endofíticos encontrados em plântulas foi relativamente muito alto tanto nos caules como em raízes, estes autores sugerem que muitos deles originamse da semente, havendo entretanto necessidade de mais estudos sobre este assunto. Também demonstraram que a população de endofíticos em hastes de milho, diminui com a maturidade da planta, de $1 \times 10^{3}$ inicialmente para $1 \times 10^{10}$, depois de 10 semanas, talvez devido a um aumento da competição pela falta de nutrientes, ou ao acúmulo de metabólitos tóxicos. Os gêneros mais comumente encontrados foram Pseudomonas e Bacillus.

Entretanto, os dados atuais relativos à patogenicidade dos endofíticos que ocorrem normalmente nos hospedeiros vegetais, se apresentam controversos. Podese visualizar melhor tal fato se forem comparados os resultados dos autores subsequentes.

Cother \& Dowling (1986), estudaram a associação de bactérias patogênicas com a podridão de bulbos de cebolas e discutiram o possível papel de bactérias endofíticas no desenvolvimento dos sintomas de patogenicidade. Após o isolamento de algumas bactérias endofíticas de tecidos internos de bulbos a reinoculação destas em bulbos sadios para ensaios de patogenicidade, resultava em isolamento de espécies patogênicas. Além disso, os autores sugeriram que estes isolados poderiam se tornar patógenos oportunistas quando da ocorrência de alterações na fisiologia do hospedeiro, devidas por exemplo a altas temperaturas durante a maturidade dos bulbos.

Entretanto, Misaghi \& Donndelinger (1990), isolaram bactérias dos gêneros Erwinia sp., Bacillus sp., Bacillus pumilus, B. brevis, Clavibacter sp., e Xanthomonas sp., de raízes, caule e flores de plantas de algodão tanto crescidas em casa-de-vegetação quanto no campo, em duas diferentes cultivares. Obtiveram altas frequências de reisolamento para Erwinia sp., nos diferentes órgãos, nas duas cultivares e caracterizaram um mutante resistente a antibiótico para esta bactéria. Para as outras espécies citadas não foram obtidos reisolamentos nos mesmos órgãos e nem mutantes. Os endofíticos isolados ou recuperados não foram patogênicos para os cultivares, alguns não sendo sequer, relatados como causadores de doenças em plantas. 
Fages \& Lux (1991) estudaram a microflora bacteriana do rizoplano e de raízes de girassol (Helianthus annus L.) cultivados em solo do sudeste da França, visando o futuro potencial destes isolados na promoção de crescimento em plantas. A maioria dos isolados foram gram negativos e de metabolismo oxidativo, o que veio confirmar a conhecida capacidade dos gram-negativos de colonizarem raizes. Os isolados gram positivos pertenciam a espécie Bacillus cereus, embora as espécies de Bacillus mais comumente encontradas em associação com raizes de plantas sejam $B$. polymyxa, B. circulans e $B$. macerans. Entre as espécies mais frequentemente encontradas estavam Agrobacterium radiobacter e Pseudomonas vesicularis. Somente quatro isolados pertencentes a espécie Azospirillum lipoferum, dentre um total de 45 fixaram nitrogênio (reduziram acetileno).

Fisher et al. (1992), isolaram bactérias e fungos endofíticos de três tipos de tecidos ( epiderme e córtex do caule, e folha) de plantas de milho sadias, e verificaram que as partes das plantas mais próximas ao solo eram mais colonizadas por bactérias que a parte mais superior das plantas. Em geral os padrões de distribuição foram diferentes entre os três tipos de tecidos estudados, com o córtex e epiderme de caule apresentando frequências de colonização quase iguais entre si e as folhas mais colonizadas que aqueles. Os isolados de bactérias mais comuns encontrados no córtex do caule foram: Enterobacter agglomerans, Klebsiella terrigena, Pseudomonas corrugata, $P$. fluorescens, $P$. marginalis e Vibrio sp.

\section{biológica de nitrogênio}

\subsubsection{Relação planta-endófito: aspectos ecológicos e da fixação}

Quispel (1988) discutiu, em sua revisão, algumas das consequências relativas ao modo de vida endofítico, indicando que este pode afetar as atividades metabólicas e de transporte, ou a viabilidade desses organismos. Na simbiose inter e intracelular, entre microrganismos fixadores de nitrogênio e plantas, o desenvolvimento de uma forma endofítica de vida para o microrganismo simbionte é essencial. Tal desenvolvimento inclui uma série de etapas na interação plantabactéria. Esta sequência de etapas somente se desenvolve se existir uma relação homóloga específica entre as plantas hospedeiras e as bactérias. Cada etapa fenotípica depende de uma correlação ótima entre os genótipos das plantas hospedeiras e os das bactérias. Isto sugere métodos apropriados visando o melhoramento genético vegetal, uma vez que, há grandes diferenças entre os 
genótipos das plantas e essas tendem a ser "menores" nos genótipos dos microrganismos, com relação à fixação biológica de nitrogênio.

Vale ressaltar aqui, a existência de interações específicas, entre os microrganismos endofiticos e plantas hospedeiras, as quais se refletem principalmente a nível fisiológico.

Estas interações dependem da atividade de muitos genes tanto da bactéria quanto da planta. Estudos sobre estes genes levou ao descobrimento de flavonóides nas plantas, os quais afetam o sistema regulatório para a transcrição de diferentes genes que desenvolvem algum papel durante a infecção e início da nodulação. A forma endofitica de vida é essencial para boa fixação de $\mathrm{N}_{2}$ e uso do $\mathrm{N}$-fixado, para a nutrição das plantas. Por outro lado, devemos ter em mente que um endofitico em muitos aspectos, está circundado pelo ambiente hostil da célula hospedeira. $O$ endofítico deve ser protegido das diferentes enzimas das células hospedeiras, tais como proteases. Pode-se conceber que algumas enzimas afetem diretamente os endofíticos. Todos estes fatores juntos sustentam a atividade de bacteróides endofíticos ou formas endofíticas de outros microsimbiontes, mas também influenciam sua habilidade e longevidade, do que depende a eficiência do sistema de fixação de $\mathrm{N}_{2}$, para nutrição da planta (Quispel, 1988).

Um estudo sobre a simbiose entre Frankia e Alnus incana, considerando o efeito do endofítico Frankia na fixação de $\mathrm{N}_{2}$ e na produção de biomassa foi realizado por Weber et al. (1989), onde avaliaram a eficiência de estirpes nativas de Frankia na fixação de $\mathrm{N}_{2}$.

Estudos relacionados com FBN (fixação biológica de nitrogênio) têm sido realizados também na busca de solução para problemas tais como aumento da eficiência de nodulação em baixas pressões de $\mathrm{O}_{2}$ em milho (Alexander \& Zuberer, 1989), limitação da infestação de nódulos de raízes de Cajanus cajan por insetos (Rivellia angulata: DIPTERA), por meio de transformação genética de genes entomocidas de Bacillus thuringiensis subsp. israelensis, expressados nos nódulos das raizes inoculadas com espécies de Bradyrhizobium transformadas (Nambiar et al., 1990).

De acordo com Döbereiner (1992a), a associação de Azospirillum com rizosfera de cereais e gramíneas tem sido uma forma alternativa com relação a simbiose entre Rhizobium e leguminosas. Entretanto, a descoberta de duas espécies de endofiticos diazotróficos em partes aéreas de cereais e outras plantas podem levar a substanciais mudanças no conceito das associações diazotróficas. 
A identificação de várias espécies de Azospirillum, formando associação com plantas não-leguminosas, expandiu as possibilidades de fixação biológica de nitrogênio em cereais e gramíneas. Estes microrganismos são considerados do solo, assim como Herbaspirillum seropedicae isolado inicialmente de raiz e caule de vários cereais. Ambas espécies apresentam crescimento aerotáctil em meio semisólido sem $\mathrm{N}$ e alta atividade da nitrogenase, assim como fraca patogenicidade para plantas (Döbereiner, 1992a).

Um outro diazotrófico, Acetobacter diazotrophicus é também considerado um endófito de plantas de cana-de-açúcar, sendo encontrado no colmo e folhas deste vegetal. Esta bactéria não foi isolada do solo e ocorre predominantemente em plantas propagadas vegetativamente. Ela foi também isolada de esporos de fungos micorrízicos vesículo-arbusculares (VAM), e pode ser introduzida em cana, sorgo e batata-doce, via infeç̧ão com VAM, usando-se seus esporos. Portanto a possibilidade de infectar plântulas de cana-de-açúcar com diazotróficos endofíticos via fungos micorrízicos vesículo-arbusculares (MVA) representa uma oportunidade ímpar de introdução de bactérias selecionadas ou melhoradas geneticamente nas plantas que então se tornariam propagáveis juntamente com os colmos (Döbereiner, 1992b).

Estas descobertas recentes abrem formas inteiramente novas de expansão da fixação biológica de nitrogênio para cereais e gramíneas. Isto já é possível, como demonstram estudos recentes de balanço de ${ }^{15} \mathrm{~N}$ e $\mathrm{N}$, em cana-de-açúcar, onde mais de $150 \mathrm{Kg} \mathrm{N} \cdot \mathrm{ha}^{-1}$. ano-1 foram obtidos através da fixação biológica de nitrogênio (Döbereiner, 1992b). Com isso, a extensão da fixação biológica de nitrogênio para cereais e gramíneas tem sido a principal linha de pesquisa com organismos endofiticos nas duas últimas décadas.

Devido ao fato das gramíneas não poderem usar o $\mathrm{N}_{2}$ molecular, assim como outros eucariotos, a melhor abordagem parece ser a procura por associações mais ou menos simbióticas de bactérias capazes de fixar $\mathrm{N}_{2}$ em cereais, melhoradas por meio de novas tecnologias. A transferência de genes para fixação de $\mathrm{N}_{2}$ para as células vegetais parece uma alternativa mais pretenciosa, que se bem sucedida, se tornaria a melhor solução. Infelizmente, o progresso neste campo é muito lento, enquanto muitas alternativas novas tornam-se disponíveis durante os últimos quinze anos, melhorando as associações já identificadas e naturalmente ocorrentes, de cereais com bactérias fixadoras de $\mathrm{N}_{2}$ (Döbereiner \& Urquiaga, 1992).

O uso de MVA deve também auxiliar a introdução de bactérias endofiticas fixadoras de $\mathrm{N}_{2}$ nas sementes de plantas tais como o sorgo açucareiro, permitindo 
desta maneira a extensão da fixação de $\mathrm{N}_{2}$ para outras culturas capazes de serem utilizadas para produção de combustíveis, em países de clima frio, onde não se cultiva comercialmente a cana-de açúcar.

Estudos de comunidades endofíticas com abordagens ecológicas vêm também de encontro com a necessidade de obtenção de dados mais abrangentes a respeito das interações planta-endofítico, como por exemplo o estudo realizado por Foster \& Fogleman (1993), que caracterizaram os tipos e freqüências de bactérias em uma comunidade. Segundo estes autores é uma tarefa difícil, quando são empregadas técnicas padronizadas de identificação de bactérias. Esta abordagem de ecologia de comunidade freqüentemente requer que cada isolado seja ensaiado em um grande número de características fisiológicas.

Estes autores relataram resultados de um levantamento das bactérias presentes em tecido necrosado de três espécies de cactus. Perfis de ácidos graxos foram utilizados para agrupar os isolados em grupos coespecíficos. As comunidades bacterianas entre os diferentes cactus foram comparadas, e discutiram-se as relações entre bactérias e espécies de Drosophila, e com aspectos químicos dos cactus. Concluiram que as distribuições dos isolados bacterianos variavam entre as diferentes espécies de cactus e que o número efetivo de espécies bacterianas para cada espécie de cactus correlacionava-se positivamente tanto com a complexidade química quanto com a concentração de glicose dos tecidos vegetais, indicando que tal padrão de distribuição é devido a diferenças na composição química das três espécies de cactus.

Cother \& Dowling (1986), isolaram bactérias endofiticas de cebola, e discutiram o possível papel destas no desenvolvimento de podridão no bulbo de cebolas, pois quando reinoculadas nas plantas, estas desenvolviam a doença. Sugeriram que essas bactérias endofiticas podem se tornar patógenos oportunistas quando mudanças na fisiologia do hospedeiro são desencadeadas por altas temperaturas, em bulbos maduros.

Ainda dentro desta linha de estudos, a abordagem dos efeitos benéficos dos microrganismos na promoção do crescimento vegetal também exemplifica a interação ao nível metabólico destes com seus hospedeiros, como no estudo desenvolvido por Fages \& Mulard (1988), que isolaram Azospirillum lipoferum e Enterobacter cloaceae da rizosfera de milho, seguida de sua inoculação em milho cultivado em vasos. A inoculação com $A$. lipoferum resultou em um forte efeito benéfico para peso de matéria seca, enquanto $E$. cloaceae resultou em um efeito menor, mas significante para vários parâmetros tais como peso de matéria seca, 
elongação das plântulas e atividade de redução do acetileno. Esta abordagem, incluindo isolamento e inoculação parece ser uma forma interessante para se estudar a promoção do crescimento vegetal por meio de interações metabólicas com microrganismos endofíticos.

Também Lalande et al. (1989), isolaram rizobactérias de milho e as avaliaram quanto a sua capacidade de promover o crescimento vegetal, através da produção de substâncias indutoras de crescimento, supressão de organismos possivelmente deletérios e capacidade de promover a absorção de nutrientes minerais. Os isolados que promoveram o crescimento vegetal pertenciam a espécie Serratia liquefaciens e gênero Pseudomonas sp, o qual foi também o mais freqüente dentre os isolados

\subsection{Aplicações Biotecnológicas dos Endofíticos}

Basicamente os microrganismos endofíticos podem ser usados na fixação biológica de nitrogênio, como visto no ítem 2.1 .2 , no controle biológico de pragas e como vetores para transformação genética de plantas. Neste tópico procura-se dar uma idéia de como os microrganismos endofíticos podem auxiliar nestes dois últimos processos citados.

\subsubsection{Antagonismo e Controle Biológico}

O uso de pesticidas para o controle de doenças da raiz de plantas, pode ser de alto custo e implicar em poluição do solo e subsolo. Além disso, poucas variedades de culturas resistentes a tipos de doenças comuns têm sido produzidas. Entretanto, o uso de agentes de controle biológico para combate a tais doenças torna-se cada vez mais importante.

O biocontrole é baseado em interações mediadas pela planta que ocorrem entre patógenos e raízes, ou entre patógenos e microrganismos antagônicos na rizosfera e rizoplano. A supressão da doença da planta por rizobactérias pode envolver secreção de sideróforos ou antibióticos e (ou) colonização agressiva da raiz por organismos que substituem ou excluem os microrganismos deletérios da rizosfera. Entretanto, a habilidade de um microrganismo colonizar o sistema radicular de uma planta hospedeira é um importante critério na seleção de microrganismos como agentes no biocontrole de doenças das raízes nos solos (De Freitas \& Germida, 1991). 
Pouco se sabe sobre o papel de bactérias endofiticas em plantas sadias, mas bactérias epifíticas e endofíticas têm sido estudadas cada vez mais como agentes no controle biológico. Do ponto de vista de controle de doenças causadas por fungos e bactérias, Pseudomonas fluorescens parece de interesse contra Sclerotium rolfsii em populações de amendoim ou Xanthomonas citri (Hasse) em arroz (Fisher et al., 1992).

Völksch et al. (1992) realizaram um levantamento qualitativo e quantitativo da flora bacteriana ocorrente na mancha-negra da soja, causada pelo patógeno Pseudomonas syringae pv. glycinea. Foram encontradas espécies consideradas saprofiticas associadas às manchas, juntamente com as patogênicas, dentre elas Erwinia herbicola apresentando atividade antibiótica contra os patógenos. Os autores consideram a possível utilização de tais saprófitos como antagonistas ao patógeno da soja causador de mancha, visando o controle da doença.

Nambiar et al. (1990), obtiveram resultados de controle biológico, ao realizarem a clonagem e verificarem a expressão de um gene entomocida em nódulos de raízes de leguminosa (Cajanus cajan), limitando desta forma a infestação por insetos que infectam os nódulos fixadores de nitrogênio destas plantas.

Poon et al. (1977), realizaram testes de antagonismo entre Xanthomonas oryzae, saprófito e patógeno de arroz, causador de queima bacteriana, e quatro isolados endofíticos provenientes de caule e raízes de arroz, verificando que apenas um destes isolados, denominado 10R, exibia atividade antagônica. Os resultados mostraram que o tempo de entrada na planta, ou seja, a sequência de entrada e a proximidade dos dois microrganismos são fatores limitantes para inibição do desenvolvimento dos sistomas da doença e também que, apesar do isolado ser endofitico no arroz, provavelmente não seria capaz de sobreviver no tecido de seu hospedeiro, se supostamente este "ativasse" seus mecanismos de defesa. Concluíram que a inibição dos sintomas causados por X.oryzae, na inoculação mixta com o isolado $10 \mathrm{R}$ era devido ao impedimento inicial de multiplicação do patógeno pela atividade inibitória produzida pelo endófito.

De Freitas \& Germida (1991), utilizaram as espécies Pseudomonas cepacia e $P$. putida no biocontrole de fungos patogênicos de trigo de inverno. Verificaram que as plantas inoculadas com as bactérias apresentaram maior peso seco de matéria, tanto nas raizes como no caule, quando comparadas às contendo somente os fungos patogênicos (Rhizoctonia solani e Fusarium solani). Todas as Pseudomonas produziram sideróforos fluorescentes quando cultivadas em meio pobre em $\mathrm{Fe}$, e 
também algum tipo de antibiótico. Muitas das vezes o estímulo de crescimento da planta atribuídos às substâncias fluorescentes produzidas por Pseudomonas, são relacionados à excreção dos sideróforos que quelam o $\mathrm{Fe}^{3+}$. Os sideróforos presumivelmente tornam o ferro menos disponível aos microrganismos patogênicos na rizosfera.

No controle biológico de pragas de culturas, Fahey (1988) descreve um sistema de proteção às culturas utilizando uma bactéria endofítica, Clavibacter xyli subsp. cynodontis transformada com um gene codificante para a produção de uma proteína letal aos insetos (alfa-endotoxina) de Bacillus thuringiensis.

A antibiose in vitro de bactéria contra vários fungos patogênicos naturais do solo foi demonstrada várias vezes. Entretanto, apenas poucos relatos tratam de atividades antagônicas in vivo. Um estudo realizado por Reddy et al. (1993) não indica correlação entre antibiose em meio de cultura líquido ou sólido e supressão da doença em plantas crescendo em "potting mix". Isto é o esperado, uma vez que numerosos mecanismos são considerados envolvidos no controle biológico incluindo competição por nutrientes e produção de sideróforos, apenas para citar dois.

Substâncias inibitórias podem, nem sempre, ser os requisitos fundamentais para atividade em controle biológico. Efeitos indiretos tais como aglutinação de hifas (no caso de fungos), e aumento bacteriano no hospedeiro podem ser importantes mecanismos de resistência a patógenos em plantas. Entretanto, a seleção de agentes para controle biológico somente com base em ensaios de antibiose in vitro, corre o risco de perda de organismos benéficos os quais provêem proteção por outros mecanismos.

A bactéria Clavibacter xyli subsp. cynodontis descrita inicialmente por Davis et al. (1984), é comumente encontrada na natureza onde coloniza o sistema vascular da forrageira Cynodon dactylon. L. (Liao \& Chen, 1981; Davis \& Augustin, 1984; Tester, 1992). Segundo Tester (1992), essa bactéria endofitica não sobrevive naturalmente fora da planta hospedeira, não persiste acima de 18 dias em resíduos de milho incorporados no solo e não é transmitida pela semente. A habilidade de viverem dentro somada à inabilidade de viverem fora das culturas alvo, constituiu um critério para a seleção de microrganismos para a coleção da InCide Company de biopesticidas (Fahey, 1988).

Muitos endofíticos são capazes de produzir componentes antibióticos em cultura e que são ativos contra bactérias patogênicas de plantas e homens como 
também outros fungos. A função primária da produção de antibiótico deve ser a da competição contra antagonistas.

Segundo Fahey (1988), diversas seriam as vantagens da utilização de sistemas que usassem microrganismos endofiticos no controle de pragas sobre os pesticidas convencionais, incluindo:

\subsubsection{Vantagens econômicas}

* Aplicação única. A inoculação de semente ou a inoculação de plantas jovens com um endofítico apropriado resulta na colonização dessa planta. Os endofíticos vivem no interior da planta e são então protegidos do ambiente externo. Produtos biológicos e químicos aplicados externamente são desprotegidos e muitas vezes requerem aplicações múltiplas.

* Dosagem pequena. A aplicação de endofíticos pode ser realizada com somente quantidades mínimas de bactéria por área. Após a aplicação, endofíticos multiplicam-se dentro de cada planta onde então o passo final da fabricação ocorre após o ponto de venda. Agroquímicos convencionais em contraposição, são aplicados externamente e em muito maior quantidade.

* Potência sustentada. Endofíticos podem produzir o agroquímico desejado por toda a vida da planta, enquanto que produtos aplicados externamente são adversamente afetados ou tornam-se ineficazes pelo ambiente e pelo crescimento subsequente da planta.

\subsubsection{Vantagens ambientais}

* Atividade contida. Os endofiticos sobrevivem e funcionam somente dentro da planta a qual eles protegem ou melhoram, enquanto produtos aplicados externamente são amplamente dispersados cada vez que são aplicados.

* Dependência da planta. Os endofíticos, por natureza, não sobrevivem fora da planta e portanto não se multiplicam ou se espalham no ambiente ou permanecem ativos após a colheita. Microrganismos aplicados externamente devem sobreviver no ambiente para serem efetivos.

* Sem resíduos tóxicos. Produtos endofíticos podem ser designados por serem ambientalmente inócuos e degradáveis. A maioria dos pesticidas aplicados externamente devem resistir à degradação para serem efetivos. 


\subsubsection{Vantagens tecnológicas}

Certos produtos endofiticos devem ter as seguintes vantagens tecnológicas sobre plantas melhoradas genéticamente:

* Desenvolvimento rápido. Mudar a genética dos microrganismos é um processo mais rápido e simples do que mudar a genética das plantas.

* Comercializar o produto cedo. O desenvolvimento de produtos baseados em endofiticos não requer programas de melhoramento de plantas, os quais requerem muitos anos.

* Ampla aplicabilidade. Produtos baseados em endofíticos podem ser designados por funcionar em uma ampla faixa de variedades úteis comercialmente de culturas alvo.

* Rendimento. Endofíticos tem um impacto mínimo na fisiologia da planta hospedeira (e.g. pouco ou nenhum efeito no rendimento, vigor ou qualidade). Em muitos casos, a alteração na genética das plantas pode reduzir substancialmente o rendimento.

* Vendas repetidas. Muitos endofíticos não são transmitidos via sementes, e fazendeiros vão ter que comprar produtos baseados nesses organismos a cada estação. Novas variedades de plantas normalmente possuem oportunidades repetidas de venda somente quando a semente comprada é um híbrido.

\subsubsection{Vetores/hospedeiros para transformação genética de plantas.}

A associação endofiticos/planta tem despertado o interesse dos biotecnologistas devido ao intrínseco potencial que apresenta. Os endofíticos geneticamente modificados, poderiam servir como vetores para introdução de genes, de resistência, ou outros, em espécies de plantas economicamente importantes, conforme vários autores vêm ressaltando em seus estudos. Fahey (1988) apresentou o primeiro relato de aproveitamento de um organismo endofítico geneticamente modificado. No caso, tratava-se de uma bactéria isolada do xilema de uma planta não cultivada, que foi transformada e introduzida em plantas de milho, para controle da broca do colmo. A bactéria Clavibacter xily subsp. cynodontis passou a expressar, no hospedeiro, o gene da endotoxina delta que recebeu do Bacillus thuringiensis. Recentemente, Tester (1992), estudando a influência de bactérias endofiticas modificadas geneticamente na composição e decomposição de resíduos de milho, verificou que os endófitos influenciaram propriedades químicas e físicas 
dos resíduos, usando plantas inoculadas com endófitos Clavibacter xyli subsp. cynodontis (MDE1) e transformantes (MDR1.3) para produção de $\delta$-endotoxina de Bacillus thuringiensis subsp. kurstaki. Os resíduos de plantas inoculadas com o MDR1.3 apresentaram mais água retida, e sua decomposição foi maior, comparando-se com plantas inoculadas com o MDE1. Porém não houve diferença significativa no grau de decomposição no solo e na concentração de $\mathrm{N}$-total entre as duas estirpes.

Nambiar et al. (1990) obtiveram sucesso na utilização do endofítico fixador de nitrogênio Bradyrhizobium, que infecta os nódulos da leguminosa Cajanus cajan, como vetor do gene que determina a produção de uma toxina inseticida de $B$. thuringiensis subsp. israelensis. O gene de interesse foi clonado em um plasmídio vetor IncQ de bactéria Gram negativa. O plasmídio construído foi transferido por conjugação para um vetor do gênero Bradyrhizobium. A construção se manteve estável nesta espécie, em ausência de seleção, e expressou o gene instalado. Os experimentos realizados em casa de vegetação com esta estirpe construída indicou que este organismo oferecia proteção contra os danos causados nos nódulos fixadores de nitrogênio, pelas larvas dos insetos dípteros da espécie Rivelia angulata.

$O$ estudo dos endofíticos de um modo geral, representa um ótimo sistema para entendimento do papel dos microrganismos na biologia de plantas superiores e, a utilização de técnicas de biologia molecular amplia as possibilidades de aproveitamento desses simbiontes na agricultura.

Entretanto, avaliando-se o impacto ecológico da utilização de microrganismos modificados genéticamente na agricultura, há de se destacar que, segundo Turner et al. (1991), o uso das técnicas de DNA recombinante para produzir produtos envolvendo microrganismos para a agricultura devem merecer atenção quanto aos possíveis riscos dos microrganismos genéticamente modificados. Dentre os principais componentes do risco de avaliação estão a dispersão, persistência, atividade biológica e estabilidade genética. Alguns microrganismos recombinantes devem ser incapazes de persistir no sítio de dispersão por longos períodos de tempo devido às condições ambientais. Alternativamente, se um microrganismo alterado genéticamente sobrevive a um estresse físico, químico e biológico ou é dispersado para um nicho mais favorável, então a atividade biológica e a estabilidade genética do organismo tornam-se fatores chave na avaliação dos riscos ambientais associados com a sua liberação. 
Turner et al. (1991), em vista do exposto acima, estudaram como a estabilidade genética de construções da bactéria endofitica Clavibacter xyli subsp. cynodontis poderia ter potencialmente um impacto tanto na eficácia do biopesticida quanto nos riscos ambientais. Nesse estudo eles examinaram tanto a deleção de sequências do gene insertado quanto as ramificações ecológicas de cada deleção.

Eles estudaram uma bactéria que continha um plasmídio autônomo incorporado ao seu cromossomo. O plasmídeo integrado continha o gene da alfaendotoxina do Bacillus thuringiensis subsp. kurstaki HD73 fundido a um gene que conferia resistência à kanamicina, um gene de resistência à tetraciclina e um replicon de $E$. coli que funciona nesta mas não em C. $x y l i$.

Essa linhagem recombinante eventualmente perdia esses genes quando crescia in vitro ou in planta. A deleção usualmente resultava na perda de todo plasmídeo integrado. $O$ evento de integração aparentemente ocorreu por recombinação homóloga. Se a integração do pCG610 no cromossomo da $C$. xyli subsp. cynodontis ocorresse por uma permuta simples na região de homologia, acontecia uma duplicação de uma porção do DNA genômico clonado na vizinhança de onde a permuta tinha ocorrido. Desde que o DNA duplicado de $C$. $x y l i$. subsp. cynodontis estaria arranjado como uma repetição direta flanqueando as sequências do plasmídio integrado, uma excisão por recombinação na região de homologia resultaria na perda do DNA integrado.

Segundo esses autores, para o desenvolvimento de um produto, seria crítico que a proteína alfa-endotoxina fosse mantida em níveis altos o suficiente para ser eficaz durante o período de crescimento. No estudo realizado por eles, colônias segregantes eram inferiores a $15 \%$ do total de colônias de $C$. xyli subsp. cynodontis isoladas de milho no final do período de crescimento. $O$ processo de segregação deveria servir como um mecanismo de segurança ambiental, em que o recombinante revertesse para uma linhagem similar, se não idêntica, à linhagem selvagem. A perda contínua do gene da alfa-endotoxina reduziria a probabilidade de atividade contra insetos que não fossem alvo em eventos desconhecidos que o recombinante endofítico escapasse do milho para um hospedeiro perene conveniente.

\subsection{RAPD (Random Amplified Polymorfic DNA)}

A deteç̧ão de variação genética é essencial para muitas pesquisas genéticas. Estas incluem estudos tão diversos como mapeamento genético, identificação de 
indivíduos, determinação parental, genética de populações e filogenia ao nível molecular (Bowditch et al., 1991).

$O$ advento da eletroforese de aloenzimas e da análise de DNA por RFLP (restriction fragment length polymorphism), tornou possível se detectar muitos polimorfismos na maioria dos organismos ao nível de proteínas ou de DNA. Estes polimorfismos genéticos são cruciais no exame de muitos dos diferentes estudos apontados acima. Especificamente, os polimorfismos podem ajudar na determinação de grupos de taxa relacionados entre si, na análise parental em espécies de animais domésticos e silvestres, na identificação de indivíduos para programas de melhoramento em cativeiro para espécies postas em perigo, em comparação de plantas selvagens e cultivadas, e na estimativa dos níveis de autofecundação e fecundação cruzada em populações. Eles devem também ser essenciais, por exemplo, no mapeamento de locus de caracteres quantitativos (QTLs), em plantas cultivadas e no mapeamento do genoma humano (Bowditch et al., 1991).

Embora técnicas modernas para estudo de polimorfismos tenham proporcionado novas pesquisas, elas têm algumas limitações. Por exemplo, análise de RFLP requer quantidades razoavelmente grandes de DNA genômico (frequentemente não disponíveis para materiais raros, antigos, e/ou materiais coletados do campo) e sondas que devem ser específicas a um grupo ou a um organismo. Ensaios de PCR (polymerase chain reaction), embora requeiram muito menos DNA genômico, dependem do conhecimento parcial ou completo, da sequência de DNA do genoma do organismo ou do gene em estudo. Williams et al. (1990) descreveram uma técnica para detectar polimorfismos de DNA que chamaram de RAPD (random amplified polymorfic DNA). A referida técnica requer apenas pequenas quantidades de DNA, e nenhum conhecimento anterior do genoma em questão é necessário. A técnica baseia-se em amplificação ao acaso de fragmentos de DNA, por meio de PCR, usando iniciadores curtos e de sequências arbitrárias. Ela detecta polimorfismos abundantes na maioria dos organismos e apresenta vantagens em certas circunstâncias, sendo uma ferramenta básica para estudos genéticos de organismos relacionados (Bowditch et al., 1991).

\subsubsection{Princípio do Método}

A técnica do RAPD faz uso da tecnologia da PCR. Pela técnica da PCR, dois oligonucleotídios específicos (geralmente de 18 a $25 \mathrm{pb}$ de comprimento), complementares a sequências que circundam o segmento alvo, são sintetizados para 
servir como "primer" para a reação de amplificação do DNA. Ao contrário, pelo RAPD um único "primer" de curto comprimento ( 9 ou 10 bases) de sequência arbitrária e uma temperatura de anelamento mais baixa do que a média usada na reação de PCR são empregadas. Estas duas modificações diminuem a especificidade da reação de forma que um número maior de fragmentos reproduzíveis pode ser amplificado nos mais complexos genomas. Os produtos de reação são geralmente analisados por eletroforese em gel de agarose, e a coloração é feita com brometo de etídio, de forma que torna-se desnecessário a utilização de isótopos radioativos que normalmente são usados na técnica de RFLP. As mutações que inibem a ligação do "primer", ou por outro lado, interferem na amplificação podem ser detectadas pela ausência da banda pertinente nestes indivíduos (Bowditch et al., 1991).

Devido aos curtos oligonucleotídeos serem capazes de servirem como "primer" para uma variedade de genomas nas condições especificadas, é possível se desenvolver um painel de "primers" universais que podem ser utilizados para detectar polimorfismos de forma direta em praticamente qualquer ser vivo usando-se apenas nanogramas de DNA molde (Bowditch et al., 1991).

Para se realizar um ensaio de RAPD, um oligonucleotídio de DNA de fita simples de sequência arbitrária é misturado com DNA genômico em presença de dNTP's (dinucleotídios monofosfatados), de uma DNA polimerase termoestável e um tampão adequado, e este é então sujeito a variações cíclicas de temperatura, típica de PCR. Os produtos de reação dependem da sequência e comprimento do oligonucleotídio, assim como das condições de reação. Numa temperatura de anelamento apropriada durante a ciclagem térmica, o "primer" de fita simples liga-se a sítios em fitas opostas do DNA genômico que estão dentro de uma distância amplificável (isto é, dentro de alguns milhares de nucleotídios), e um segmento discreto de DNA é amplificado. A presença ou ausência deste produto específico, embora amplificado com um "primer" arbitrário, será diagnóstico para os sítios de ligação do oligonucleotídio no DNA genômico. $\mathrm{Na}$ prática, considerando-se o objetivo pretendido, a reação de amplificação do DNA é repetida num grupo de amostras de DNA com muitos "primers" diferentes, em condições que resultam em muitas bandas amplificadas para cada "primer". As bandas polimórficas são notadas, por exemplo, entre pais de um cruzamento, e os polimorfismos podem ser mapeados numa população segregante. Frequentemente, um único "primer" pode ser usado para identificar vários polimorfismos, cada um referente a um diferente locus ( Williams et al., 1993). 


\subsubsection{Aplicações do Método}

Dentre as aplicações do método de RAPD, destacamos uma maior facilidade na abordagem de estudos de mapeamento genético, genética de populações e taxionomia molecular.

De acordo com Williams et al. (1993), quando um marcador RAPD é detectado como um segmento de DNA amplificado de um dos parentais num cruzamento, mas não no outro parental, o marcador pode ser rastreado na progênie segregante e pode ser relacionado a um locus num mapa genético. E segundo resultados destes mesmos autores, os RAPDs podem prover marcadores de DNA em regiões genômicas que não são acessíveis à análise por RFLP, devido à presença de sequências de DNA repetitivo.

Os marcadores RAPD são marcadores dominantes, porque a presença de uma dada banda não distingue se seu locus respectivo é homozigoto ou heterozigoto. Se for necessário identificar regiões heterozigotas, dois marcadores RAPD ligados, cada um amplificando para um dos parentais, podem ser utilizados como um par. Po exemplo, a amplificação de ambos marcadores do par é diagnóstico para uma região genômica heterozigota, com uma incerteza igual à distância de recombinação entre os dois marcadores. A utilização de marcadores aos pares requer duas vezes mais marcadores que em comparação a marcadores codominantes (RFLPs). Uma outra alternativa seria a excisão das bandas e utilização destas como sondas para detectar RFLPs co-dominantes. Também é possível quantificar a intensidade de bandas RAPD usando-se técnicas densitométricas padronizadas. Uma banda RAPD derivada de uma região heterozigota teria metade da intensidade da banda derivada de uma região homozigota (Williams et al., 1993).

Os marcadores de DNA podem ser utilizados para medir a similaridade entre indivíduos dentro de populações artificiais ou naturais (por meio de cruzamentos) dentro de uma espécie. Para se comparar a eficiência relativa dos marcadores de RAPD versus RFLP, deve ser considerado que um único "primer" arbitrário geralmente amplificará vários loci genéticos independentes, mas pode ser usado para identificar a presença de apenas um alelo. Apenas a presença ou ausência de uma banda RAPD pode ser detectada. Ao contrário, as sondas de RFLP podem geralmente ser usadas para ensaiar um ou poucos loci de sequências nucleotídicas complementares, e também para detectar alelos múltiplos em cada locus devido às variações nos tamanhos dos fragmentos de RFLP. Enquanto em milho oito alelos foram distinguidos num único locus por uma sonda para RFLP, em soja a maioria 
dessas sondas detectaram não mais do que dois alelos em cada um dos dois loci homólogos. Entretanto, pode ser recomendável usar as sondas RFLP, para estudos de populações de fecundação cruzada, geneticamente diversas, como o milho, enquanto os marcadores RAPD seriam adequados para análise de espécies mais uniformes, autógamas como a soja. A diversidade entre populações e espécies é influenciada por múltiplos fatores, incluindo ciclo de vida, tempo de geração, fecundação aberta ou fechada, tipos de dispersão de pólen, limites geográficos e nicho ecológico. Estas características biológicas deveriam ser consideradas para o desenvolvimento de estratégias para se quantificar a diversidade com marcadores genéticos ao nível de DNA (Williams et al., 1993).

De acordo com Williams et al. (1993), a amplificação com "primers" arbitrários é extremamente sensível para mudanças de uma base no sítio alvo do "primer". Esta característica sugere que os RAPDs são altamente úteis para a análise filogenética entre indivíduos muito interelacionados, embora menos úteis para a análise de indivíduos geneticamente diversos.

\subsubsection{Utilização do RAPD em estudos relacionados a bactérias}

Wang et al. (1993), apresentaram uma análise de RAPD de isolados de $E$. coli. Os resultados desses autores mostram concordância geral entre o agrupamento das estirpes de E. coli, obtido por RAPD e por tipagem MLEE (multilocus enzyme eletrophoretictyping method).e concluíram que a tipagem por RAPD, com poucos "primers" arbitrários, é muito mais sensível do que tipagem com 20 enzimas diagnóstico, usado no outro método, e recomendam a técnica como uma ferramenta para análise epidemiológica e genética de populações de diversos organismos.

Harrison et al. (1992), demonstraram que, o uso de "primers" ao acaso, selecionados na ausência de uma sequência alvo, mostrou-se efetivo na produção de amplificações do DNA que produziram "fingerprints" os quais foram característicos de organismos individuais. A amplificação do DNA por "primers" ao acaso foi aplicada ao DNA de isolados de Rhizobium leguminosarum biovar trifolli. Os produtos de amplificação foram produzidos usando-se vários "primers", e os "fingerprints" resultantes permitiram a diferenciação das estirpes. Entretanto, a efetividade dos "primers" foram dependentes do comprimento e conteúdo de CG. Foi também possível amplificar o DNA diretamente das células em cultura e no tecido do nódulo. A lise celular foi obtida simplesmente por calor, aplicado no estágio inicial de denaturação do DNA, durante a reação térmica. A habilidade de 
produzir padrões de amplificação variados, de diferentes isolados de Rhizobium, especialmente direto à partir dos nódulos, dá a este método um potencial de utilização no exame de estruturas e relações genéticas nas populações de Rhizobium.

Martin-Kearley et al. (1994), estudaram 80 estirpes regionais de Vibrio, isoladas a partir de águas frias sazonais próximas a Terra-Nova (Canadá), e um certo número de estirpes de referência, pertencentes as especies $V$. splendidus $e$ V.ordalii.As estirpes regionais foram isoladas da alga marrom Alaria esculenta e do marisco gigante Placopecten magellanicus. Estas estirpes que se reproduzem a $4^{\circ} \mathrm{C}$, foram agrupadas de acordo com sua reação para arginina-dehidrolase e analisadas por análise numérica. Depois de estudadas as características fenotípicas as estirpes foram submetidas a reação de PCR-RAPD, e verificou-se que as estirpes regionais foram significativamente diferentes de V. splendidus ou de V.ordalii. Em geral, as estirpes regionais isoladas de algas marinhas formaram um grupo a parte daquelas isoladas do marisco, indicando a variabilidade dentro do grupo. Algumas estirpes, particularmente as provenientes de algas marinhas, foram capazes de utilizar maior parte dos compostos que foram examinados como fontes únicas de carbono e energia.

Estes são apenas alguns exemplos de utilização da técnica de RAPD em bactérias, outros estudos vêm sendo realizados, o que torna tal técnica propícia para pesquisas genéticas em isolados do ambiente, dos quais muito pouco ou nada se conhece, quanto a sua biologia e variabilidade. 


\section{MATERIAL E MÉTODOS}

\subsection{Material Biológico e Locais de coleta.}

\subsubsection{Linhagens de milho utilizadas para Isolamento de Bactérias}

Foram utilizadas as populações de milho BR-105 e BR-106 (do Centro Nacional de Pesquisa do Milho e Sorgo - CNPMS/EMBRAPA), assim como híbridos simples, originados de cruzamentos de linhagens puras dessas duas populações, e denominados P1, P2 e P1x2, respectivamente. Estas populações apresentam elevada capacidade geral de combinação (Naspolini Fo. et al., 1981), o híbrido intervarietal é muito produtivo, apresentando heterose elevada tanto em relação à média das populações parentais quanto em relação à população superior. As populações estão descritas a seguir:

BR-105. A população BR-105 originalmente foi denominada de Suwan-DMR, tendo sido obtida na Tailândia através de seleção entre progênies S1. Foi introduzida no Brasil em 1976, onde já foi submetida a cinco ciclos de seleção com progênies de irmãos germanos. Esta população possui porte baixo, ciclo precoce, grãos alaranjados duros, e baixa depressão por endogamia (Souza Jr. et al., 1993).

BR-106. A população BR-106 foi obtida pelo cruzamento do composto formado de variedades tardias de porte alto (Centralmex, Compostos Dentados de Maya) com o BR-108 (Tuxpeño-1) de ciclo precoce e porte baixo. Após duas gerações de recombinação, seguiram-se três ciclos de seleção recorrente intrapopulacional para redução da altura da planta e espiga. Apresenta ciclo precoce, porte baixo, e grãos dentados de coloração amarela (Souza Jr. et al., 1993). 


\subsubsection{Locais de Coleta}

As plantas destas populações foram cultivadas durante os meses de Novembro/1993 a Janeiro/1994 (60 a 75 DAP), em dois experimentos idênticos, em dois locais diferentes, distando entre si por um raio de aproximadamente $10 \mathrm{Km}^{2}$ : Fazenda Areião (Local 1) e Caterpillar (Local 2), ambos Campo Experimental do Departamento de Genética da ESALQ/USP em Piracicaba,SP. Os tipos de solo das duas áreas experimentais são dados a seguir ${ }^{1}$ : Fazenda Areião: Latossolo Vermelho Escuro Distrófico Ondulado, com $7 \%$ de declividade; Caterpillar: Latossolo Vermelho Amarelo Distrófico, levemente ondulado, possuindo uma camada de areia na superficie e $3 \%$ de declividade

Foram retirados, ao acaso, de cada população parental P1 e P2, nove plantas, representando três genótipos, e da população de híbridos simples, 18 plantas, representando seis diferentes genótipos (Tabela 3.1), para inicialmente estudar a ocorrência de bactérias endofiticas nos diferentes locais, considerando-se os mesmos tratamentos para ambos locais. A análise estatística utilizada para análise dos referidos experimentos encontram-se detalhadas no ítem 3.7.

Explantes $(2 \times 4 \mathrm{~cm})$ da terceira folha apical das plantas de milho foram utilizados para isolamento de bactérias em meios de cultura apropriado. Foram realizadas duas coletas em épocas diferentes, com intervalo de 30 dias entre si, a primeira com plantas de 6,5 semanas de cultivo e a segunda de 10 semanas.

\subsubsection{Linhagens de Microrganismos Utilizadas}

Os fungos utilizados nos ensaios de antagonismo fazem parte do estoque de microrganismos do Laboratório de Genética de Microrganismos da ESALQ/USP. Os endofíticos: Fusarium moniliforme, isolado de sementes de milho (Pamphile et al.,1995), Penicillium purpurogenum e $P$. spinulosum, isolados de raiz de milho (Silva, 1992; Ribeiro, 1995); e as linhagens 1671 e 4626, de Penicillium chrysogenum, produtores de penicilina, não endofíticos (Bueno, 1995), foram as linhagens ensaiadas no experimento.

Para a análise de RAPD dos isolados de bactérias endofíticas foram utilizados como espécies tipo comparativas, as linhagens de Bacillus megaterium 3026(ATCC-14581) e Bacillus subtilis 2471(ATCC-6051), obtidos da Coleção de

\footnotetext{
${ }^{1}$ Comunicação pessoal: Engenheiro Agrônomo Cláudio Roberto Segatelli (Depto. Genética-ESALQ/USP).
} 
Culturas da Fundação Tropical de Pesquisa e Tecnologias "André Tosello" (CCTFTPTAT). As linhagens de microrganismos endofíticos isolados e identificados no presente estudo, encontram-se criopreservados a $-70^{\circ} \mathrm{C}$ e/ou liofilizados na CCTFTPTAT.

Tabela 3.1. Relação das linhagens e híbridos simples retirados ao acaso das populações P1 (BR-105), P2 (BR-106) e P1x2 (Hibridos Simples de P1 e P2), empregados no experimento

\begin{tabular}{ll}
\hline Genótipos homozigotos puros & Híbridos Simples \\
\hline $06-06-3 \mathrm{~A}^{*}$ & $18.1 \times 1.4$ \\
\hline $06-08-1 \mathrm{~A}^{*}$ & $8.2 \times 33.5$ \\
\hline $06-03-5 \mathrm{~B}^{*}$ & $3.5 \times 18.6$ \\
\hline $05-17-1 \mathrm{~A}^{*}$ & $24.7 \times 05.2$ \\
\hline $05-01-4 \mathrm{~B}^{*}$ & $44.1 \times 23.2$ \\
\hline $05-05-2 \mathrm{~A}^{*}$ & $37.5 \times 19.1$ \\
\hline
\end{tabular}

* onde o primeiro número corresponde à população.

\subsection{Meios de Cultura}

A seguir são detalhadas as formulações dos meios de cultura utilizados no presente trabalho.

\subsubsection{Meio Nutriente-ágar (NA) e Caldo Nutriente (CN)}

Extrato de carne

Peptona

Ágar

Água destilada q.s.p.
$3,0 \mathrm{~g}$

$5,0 \mathrm{~g}$

$15,0 \mathrm{~g}$

$1000 \mathrm{ml}$

$\mathrm{O} \mathrm{pH}$ foi acertado para 7,0+/- 0,2 e o meio foi autoclavado em erlenmeyer a $127^{\circ} \mathrm{C}(1,5 \mathrm{~atm})$, por 15 minutos.

$\mathrm{O}$ meio $\mathrm{CN}$ foi preparado com as mesmas quantidades de substâncias descritas para o preparo do meio NA, com a diferença de não ter sido adicionado o ágar. Em seguida ele foi autoclavado a $120^{\circ} \mathrm{C}(1,0 \mathrm{~atm})$, por 15 minutos.

\subsubsection{Meio TSA (Triptcsoy-ágar)}

Triptona

Soytone(Peptona de soja)

$\mathrm{NaCl}$
$15,0 \mathrm{~g}$

$15,0 \mathrm{~g}$

$$
5,0 \mathrm{~g}
$$


Ágar

20,0

Água destilada q.s.p.

$1000 \mathrm{ml}$

$\mathrm{O} \mathrm{pH}$ foi acertado para $7,0+/-0,2$, e o meio foi autoclavado a $120^{\circ} \mathrm{C}$ $(1,0 \mathrm{~atm})$, por 15 minutos.

\subsubsection{Esculina ágar}

Esculina

$0,1 \mathrm{~g}$

Peptona

$1,0 \mathrm{~g}$

$\mathrm{NaCl}$

$0,5 \mathrm{~g}$

Citrato de ferro III

$0,05 \mathrm{~g}$

Água destilada

Ágar

$1000 \mathrm{ml}$

$20,0 \mathrm{~g}$

$\mathrm{O} \mathrm{pH}$ foi acertado para 6,8 - 7,0. Autoclavou-se em erlenmeyer a $120^{\circ} \mathrm{C}(1,0 \mathrm{~atm})$, por 15 minutos.

\subsubsection{Meio Amido}

Peptona

Extrato de carne

Amido solúvel

Ágar

Água destilada
$0,5 \mathrm{~g}$

$0,3 \mathrm{~g}$

$1,0 \mathrm{~g}$

$1,5 \mathrm{~g}$

$100 \mathrm{ml}$

$\mathrm{O} \mathrm{pH}$ foi acertado para $6,8-7,0 . \mathrm{O}$ amido foi adicionado e deixado em $10 \mathrm{ml}$ de água destilada. A seguir foi misturado com os outros ingredientes e colocado o restante da água $(90 \mathrm{ml})$. Aqueceu-se e esterilizou-se a $120^{\circ} \mathrm{C}(1,0 \mathrm{~atm})$, por 15 minutos.

\subsubsection{Caseína (Leite Desnatado)}

Solução A

Leite em pó desnatado

Água destilada

Solução B

Ágar

Água destilada
$10,0 \mathrm{~g}$

$500 \mathrm{ml}$

$15 \mathrm{~g}$

$500 \mathrm{ml}$

As duas soluções foram autoclavadas separadamente. A solução $A$ foi esterilzada a $108^{\circ} \mathrm{C}$, por 10 minutos, e a solução $\mathrm{B}$ a $120^{\circ} \mathrm{C}(1,0 \mathrm{~atm})$, por $15 \mathrm{~min}$. Após retirada da autoclave, deixou-se resfriar até $45^{\circ} \mathrm{C}$ aproximadamente. Do 
mesmo modo deixou-se resfriar o Leite desnatado e as 2 partes foram misturadas, colocando sempre o ágar sobre o leite desnatado.

\subsubsection{Citrato de Simmons}

Formulação a partir do meio pronto Simmons Citrate:

Sulfato de magnésio

$0,2 \mathrm{~g}$

Fosfato de Amônio monobásico

$1,0 \mathrm{~g}$

Fosfato de Potássio dibásico

$1,0 \mathrm{~g}$

Citrato de Sódio

$2,0 \mathrm{~g}$

Cloreto de Sódio

$5,0 \mathrm{~g}$

Ágar

$15,0 \mathrm{~g}$

Azul de bromotimol

$0,08 \mathrm{~g}$

Água destilada

$1000 \mathrm{ml}$

$\mathrm{O}$ meio foi dissolvido e ajustou-se o $\mathrm{pH}$ a 7,0 e distribui-se em tubos (2,0 ml por tubo). Autoclavou-se a $120^{\circ} \mathrm{C}(1,0 \mathrm{~atm})$, por 15 minutos. Inclinou-se bastante o tubo não deixando base para inóculo, e sim uma grande superficie inclinada.

\subsubsection{EPM}

Solução Base (A):

Triptona

Extrato de Carne

Cloreto de Sódio

Fosfato de Sódio dibásico (NaH2PO4.5
$10,0 \mathrm{~g}$

$2,0 \mathrm{~g}$

$5,0 \mathrm{~g}$

$\mathrm{H} 2 \mathrm{O}$ )

L-Triptofano

Solução Alcóolica de Azul de

Bromotimol 1,5\%

Ágar

Água destilada
$2,0 \mathrm{~g}$

$1,0 \mathrm{~g}$

Adicionou-se todos os ingredientes (menos o ágar) até dissolução completa. $\mathrm{O}$ pH foi ajustado para 7,4. Colocou-se o ágar e esterilizou-se.

Solução de Indicador e Substrato (B):

Citrato de Ferro Amoniacal $2,0 \mathrm{~g}$

Tiossulfato de Sódio (Na2S2O3.5 H2O) 2,0g

Glicose

$10,0 \mathrm{~g}$ 
Uréia $40,0 \mathrm{~g}$

Água destilada

$85 \mathrm{ml}$

Misturaram-se os elementos à água destilada e aqueceu-se em banhomaria a $65^{\circ}$ com agitação constante até dissolução completa, mantendo-se a mesma temperatura por 1 hora. $\mathrm{O}$ preparo final foi feito misturando-se as seguintes quantidades de solução A e B:

Solução A $1000 \mathrm{ml}$

Solução B $17,5 \mathrm{ml}$

Após resfriar a base $\mathrm{A}$ a $65^{\circ} \mathrm{C}$, adicionou-se a solução $\mathrm{B}$ com assepsia. A mistura foi homogeneizada e distribuída em volumes de $4 \mathrm{ml}$ em tubos de $12 \mathrm{x}$ $120 \mathrm{~mm}$ previamente esterilizados, deixando solidificar em posição inclinada, de maneira a se obter uma base de pelo menos $3,5 \mathrm{~cm}$. Realizou-se a prova de esterilidade. $\mathrm{O}$ meio adquiriu uma coloração verde.

\subsubsection{Gelatina}

Extrato de Carne

$3,0 \mathrm{~g}$

Peptona

$5,0 \mathrm{~g}$

Gelatina

$120,0 \mathrm{~g}$

Água destilada

$1000 \mathrm{ml}$

Adicionou-se gelatina na água e deixou-se descansar por 15 a 30 minutos. Aqueceu-se para dissolver a gelatina e adicionaram-se os outros ingredientes. $\mathrm{O} \mathrm{pH}$ foi ajustado para 7,0 e esterilizou-se a $120^{\circ} \mathrm{C}(1,0 \mathrm{~atm})$, durante 20 minutos.

\subsubsection{Indol}

Proteose Peptona

$2,0 \mathrm{~g}$

Cloreto de Sódio

$0,5 \mathrm{~g}$

Ágar

$0,1 \mathrm{~g}$

Tioglicolato de Sódio

$0,1 \mathrm{~g}$

Fosfato de Sódio

$0,2 \mathrm{~g}$

Glicose

$0,1 \mathrm{~g}$

Água destilada

$1000 \mathrm{ml}$

Misturaram-se todos os ingredientes (menos o ágar) na água. Ajustouse o pH para 7,2. Dissolveu-se o ágar e distribuiu-se em tubos com 4 a $5 \mathrm{ml}$ de meio em cada. Autoclavou-se a $120^{\circ} \mathrm{C}(1,0 \mathrm{~atm})$, por 15 minutos. 


\subsubsection{MacConkey}

Peptona

Proteose Peptona

$17,0 \mathrm{~g}$

Lactose

$3,0 \mathrm{~g}$

Sais Biliares

$10,0 \mathrm{~g}$

Cloreto de Sódio

$1,5 \mathrm{~g}$

Ágar

$5,0 \mathrm{~g}$

Vermelho Neutro

$13,5 \mathrm{~g}$

Cristal Violeta

$0,03 \mathrm{~g}$

Água destilada

$0,001 \mathrm{~g}$

$1000 \mathrm{ml}$

Dissolveu-se o meio em água destilada e autoclavou-se a $120^{\circ} \mathrm{C}(1,0$ atm), por 15 minutos. $\mathrm{O} \mathrm{pH}$ foi ajustado para 7,0.

\subsubsection{Meio de Redução de Nitrato a Nitrito} Formulação:

Triptona

Fosfato Dissódico

Glicose

Nitrato de Potássio

Ágar

Água destilada
$4,0 \mathrm{~g}$

$0,4 \mathrm{~g}$

$0,2 \mathrm{~g}$

$0,2 \mathrm{~g}$

$0,2 \mathrm{~g}$

$200 \mathrm{ml}$

Dissolveu-se o meio e distribuiu-se em tubos com aproximadamente 6 $\mathrm{ml}$ em cada. Esterilizou-se a $120^{\circ} \mathrm{C}(1,0 \mathrm{~atm})$, por 15 minutos. $\mathrm{O} \mathrm{pH}$ foi ajustado para 7,0 .

\subsubsection{O/F (Hugh Leifson)}

Foram usados dois meios diferentes, um para bactérias Gram positivas e outro para as Gram negativas.

$\mathrm{O} / \mathrm{F}(+)$, para as Gram positivas;

Triptona

Extrato de Carne

Glicose

Bromocresol Púrpura

Ágar

Água destilada
$10,0 \mathrm{~g}$

$1,0 \mathrm{~g}$

$10,0 \mathrm{~g}$

$0,04 \mathrm{~g}$

$2,0 \mathrm{~g}$

$1000 \mathrm{ml}$ 
$\mathrm{O} / \mathrm{F}(-)$, para as Gram negativas

Triptona

Cloreto de Sódio

Fosfato Dipotássico

Azul de Bromotimol

Ágar
$2,0 \mathrm{~g}$

$5,0 \mathrm{~g}$

$0,3 \mathrm{~g}$

$0,08 \mathrm{~g}$

$2,0 \mathrm{~g}$

Dissolveram-se todos os ingredientes (menos o ágar) e acertou-se o pH para 7,0. Adicionou-se o ágar e distribuiu-se aproximadamente $6 \mathrm{ml}$ por tubo. Autoclavou-se a $120^{\circ} \mathrm{C}(1,0 \mathrm{~atm})$, por 10 minutos.

\subsubsection{Tioglicolato}

Casitona

Extrato de Levedura

$15,0 \mathrm{~g}$

Dextrose

$5,0 \mathrm{~g}$

Cloreto de Sódio

$5,5 \mathrm{~g}$

L-Cistina

$2,5 \mathrm{~g}$

Tioglicolato de Sódio

$0,5 \mathrm{~g}$

Ágar

$0,5 \mathrm{~g}$

Resazurina

$0,75 \mathrm{~g}$

$0,001 \mathrm{~g}$

Aqueceu-se até dissolver completamente os componentes do meio. Dispensou-se em tubos de rosca (aproximadamente 12,5ml por tubo). Autoclavou-se a $120^{\circ} \mathrm{C}(1,0 \mathrm{~atm})$, por 15 minutos e ajustou-se o $\mathrm{pH}$ para 7,0 .

\subsubsection{TSI (Triple Sugar Iron )}

Extrato de carne

Extrato de levedura

Peptona

Proteose peptona

Dextrose

Lactose

Sacarose

Sulfato ferroso

Cloreto de Sódio

Tiosulfato de Sódio

Phenol red
$3,0 \mathrm{~g}$

$3,0 \mathrm{~g}$

$15,0 \mathrm{~g}$

$5,0 \mathrm{~g}$

$1,0 \mathrm{~g}$

$10,0 \mathrm{~g}$

$10,0 \mathrm{~g}$

$0,2 \mathrm{~g}$

$5,0 \mathrm{~g}$

$0,3 \mathrm{~g}$

$0,024 \mathrm{~g}$ 
Ágar

$12,0 \mathrm{~g}$

Dissolveu-se o meio e distribuiu-se $4,0 \mathrm{ml}$ por tubo. Autoclavou-se a $120^{\circ} \mathrm{C}(1,0 \mathrm{~atm})$, por 15 minutos e ajustou-se o $\mathrm{pH}$ para 7,0 .

\subsubsection{Voges Proskauer e Vermelho de Metila}

Preparo do meio base:

Proteose peptona

$5,0 \mathrm{~g}$

Glicose

$5,0 \mathrm{~g}$

Fosfato dipotássico

$5,0 \mathrm{~g}$

Água destilada $1000 \mathrm{ml}$

Misturaram-se todos os ingredientes e distribuiu-se $2,0 \mathrm{ml}$ por tubo. Autoclavou-se a $120^{\circ} \mathrm{C}(1,0 \mathrm{~atm})$, por 15 minutos e ajustou-se o $\mathrm{pH}$ para 7,0 .

\subsubsection{Meio SIM (sulfeto, indol, motilidade)}

Peptona

Extrato de carne

Ferro peptonizado

Tiossulfato de sódio

Ágar

Água destilada
$30,0 \mathrm{~g}$

$3,0 \mathrm{~g}$

$0,2 \mathrm{~g}$

$0,025 \mathrm{~g}$

$3,0 \mathrm{~g}$

$1000 \mathrm{ml}$

Dissolveu-se os componentes do meio em água destilada e ajustou-se

o $\mathrm{pH}$ para 7,0. Distribuiu-se o meio em tubos de modo que ficassem em uma profundidade de cerca de $7,5 \mathrm{~cm}$ e esterilizou-se a $120^{\circ} \mathrm{C}(1,0 \mathrm{~atm})$, por 15 minutos. Os meios nos tubos se solidificaram na posição vertical.

\subsubsection{Meio Mili}

Extrato de levedura

Peptona

Triptona

L-lisina

Glicose

Ágar

Bromo-cresol púrpura

Água destilada
$3,0 \mathrm{~g}$

$10,0 \mathrm{~g}$

$10,0 \mathrm{~g}$

$10,0 \mathrm{~g}$

$1,0 \mathrm{~g}$

$2,0 \mathrm{~g}$

$0,02 \mathrm{~g}$

$1000 \mathrm{ml}$ 
Acertou-se o $\mathrm{pH}$ para 6,5. Distribuiu-se em volume de $5 \mathrm{ml}$ em tubos. Esterilizou-se a $120^{\circ} \mathrm{C}(1,0 \mathrm{~atm})$, por 15 minutos, e o meio foi deixado solidificar nos tubos em posição vertical. O meio pronto apresentou cor roxa.

\subsubsection{Uréia}

$\mathrm{KH}_{2} \mathrm{PO}_{4}$

$\mathrm{K}_{2} \mathrm{HPO}_{4}$

$\mathrm{NaCl}$

Álcool etílico

Uréia

Água destilada
$0,1 \mathrm{~g}$

$0,1 \mathrm{~g}$

$0,5 \mathrm{~g}$

$1,0 \mathrm{ml}$

$2,0 \mathrm{~g}$

$1000 \mathrm{ml}$

Acertou-se o $\mathrm{pH}$ para 7,0. Após dissolver os reagentes, adicionou-se uma solução de vermelho de fenol $0,02 \% \mathrm{p} / \mathrm{v}$, até que o meio se tornasse amarelo claro.

\subsubsection{Meio Egg Yolk}

Caldo nutriente

$100 \mathrm{ml}$

Bacto-egg yolk 5,0g

Dissolveu-se o Bacto-egg yolk no caldo nutriente. Autoclavou-se a $120^{\circ} \mathrm{C}(1,0 \mathrm{~atm})$, por 15 minutos e distribuiu-se $15 \mathrm{ml} /$ placa.

\subsection{Soluções, Reagentes e Tampões}

\subsubsection{Azul de bromotimol}

Azul de bromotimol

$0,2 \mathrm{~g}$

Álcool etílico P.A

$100 \mathrm{ml}$

Dissolveu-se o azul de bromotimol no álcool, guardando-se em seguida em frasco com rosca em refrigerador a $4^{\circ} \mathrm{C}$.

\subsubsection{Solução corante de Lugol}

Iodo

Iodeto de Potássio

Água destilada

Triturar em almofariz o iodo em presença de 1 a $2 \mathrm{ml}$ de água; a dissolução é rápida. Verter aos poucos o restante da água destilada, continuar a trituração. Guardar em frasco escuro. 


\subsubsection{Solução corante de Safranina}

Safranina

$$
1,25 \mathrm{~g}
$$

Álcool etílico

$50 \mathrm{ml}$

Água destilada

$500 \mathrm{ml}$

Dissolveu-se a safranina no álcool etilico e completou-se o volume com a água destilada.

3.3.4. Solução corante de cristal violeta Solução A:

Cristal violeta

$6,0 \mathrm{~g}$

Álcool Etílico P.A

$60,0 \mathrm{~g}$

Solução B:

Oxalato de amônio

$2,4 \mathrm{~g}$

Água destilada $240 \mathrm{ml}$

Misturaram-se as soluções $A$ e $B$, que foram estocadas a $4^{\circ} \mathrm{C}$, em frasco escuro.

\subsubsection{Cloreto férrico}

Cloreto férrico $(\mathrm{FeCl} 3)$ $10,0 \mathrm{~g}$ Água destilada $100 \mathrm{ml}$

Dissolveu-se o cloreto férrico na água e estocou-se em frasco escuro.

\subsubsection{Reativo de Kovac's}

Álcool amílico ou isoamílico $150 \mathrm{ml}$

Dimetilaminobenzaldeído $10,0 \mathrm{~g}$

Ácido clorídrico $(\mathrm{HCl})$ concentrado $50 \mathrm{ml}$

Dissolveu-se o aldeído no álcool. Adicionou-se o ácido lentamente. Estocou-se em frasco escuro.

\subsubsection{Reagente de Oxidase}

Solução A

Hidrocloreto

de tetrametil-p-

fenilenodiamino

$$
1,0 \%
$$


Solução B

alfa-naftol em metanol $\quad 1,0 \%$

Misturaram-se as soluções A e B, e estocou-se a $4^{\circ} \mathrm{C}$.

\subsubsection{Nitrato (Solução A+B)}

Solução A

Ácido sulfanílico

Ácido acético

$0,8 \mathrm{~g}$

Solução B

Alfa-naftalina $5 \mathrm{~N}$

$100 \mathrm{ml}$

Ácido acético 5N

$0,5 \mathrm{~g}$

$100 \mathrm{ml}$

Misturaram-se as duas soluções volumétricamente e estocou-se em frasco escuro.

3.3.9. Vermelho de metila

Vermelho de metila

Álcool etílico 95\%v/v

$0,1 \mathrm{~g}$

Água destilada

$300 \mathrm{ml}$

$200 \mathrm{ml}$

Dissolveu-se o corante no álcool, adicionando-se em seguida a água destilada.

\subsubsection{Reagente de Voges Proskauer}

Alfa-naftol

álcool absoluto

Solução aquosa de KOH

\subsubsection{Clorofane}

Fenol

Clorofórmio

\subsubsection{Clorofil}

Clorofórmio

Álcool Isoamílico
$240 \mathrm{ml}$

$5,0 \mathrm{~g}$

$100 \mathrm{ml}$

$40 \% \mathrm{v} / \mathrm{v}$

$50 \%$

$50 \%$

$10 \mathrm{ml}$ 
Foram utilizados dNTP's adquiridos na Pharmacia, em uma mistura de concentração final igual a $20 \mathrm{mM}$. Estes foram diluídos, para utilização em uma concentração estoque de $2,5 \mathrm{mM}$.

\subsubsection{Enzima Taq-DNApolimerase}

A enzima Taq-DNApolimerase, constituída por um único polipeptídio de aproximadamente $94 \mathrm{KDa}$ adquirida da GIBCO-BRL, (500 unidades em tubos de $5 \mathrm{U} / \mathrm{ul}$ ). Uma unidade incorpora $10 \mathrm{nmol}$ de desoxirribonucleotídio em material ácido precipitável em 30 minutos a $74^{\circ} \mathrm{C}$.

\subsubsection{Fenol saturado (Modificado de Maniats et al., 1989)}

Foram dissolvidas em banho-maria $50 \mathrm{~g}$ de fenol cristalizado, e

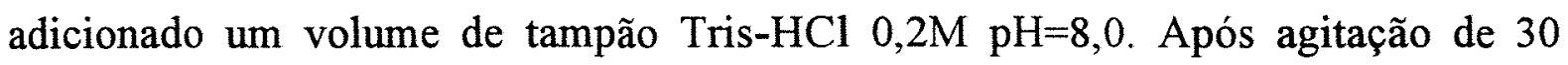
minutos para equilíbrio do $\mathrm{pH}$, foi retirada a fase aquosa e o procedimento repetido. Em seguida, foi adicionado $1 / 10$ do volume final de tampão Tris- $\mathrm{HCl} 0,2 \mathrm{M} \mathrm{pH=8,0}$ e estocado em frasco escuro a $4^{\circ} \mathrm{C}$.

\subsubsection{Gel de agarose $(0,8 \%)$}

Agarose A-0169 (Sigma) $\quad 0,8 \mathrm{~g}$

Tampão TEB $1 \mathrm{x} \quad 100 \mathrm{ml}$

\subsubsection{Gel de agarose $(1,5 \%)$}

Agarose A-0169 (Sigma) 1,5g

Tampão TEB 1x 100ml

\subsubsection{Solução de Oligonucleotídios}

Foram utilizados oligonucleotídios em "Kits" (OPERON Technologies), em quantidade aproximada de $14 \mu \mathrm{g}$. Adicionou-se água esterilizada aos oligonucleotídios que vêm na forma liofilizada, de modo a se obter uma solução estoque na concentração de $4 \mathrm{mM}$. A molaridade de cada oligonucleotídio é fornecida pelo fabricante.

\subsubsection{RNAse}

Foi preparada na concentração de $25 \mathrm{mg} / \mathrm{ml}$, em $10 \mathrm{mM}$ de Tris- $\mathrm{HCl}$ $(\mathrm{pH}=7,5)$ e $15 \mathrm{mM}$ de $\mathrm{NaCl}$. Foi aquecida a $100^{\circ} \mathrm{C}$, por 15 minutos e estocada em congelador a $-20^{\circ} \mathrm{C}$. 


\subsubsection{Solução de Brometo de Etídio (MANIATS et al, 1989)}

Foi dissolvido $1,0 \% \mathrm{p} / \mathrm{v}$ de brometo de etídio em água destilada, agitado por várias horas e estocado à temperatura ambiente. No momento do uso $3 \mu \mathrm{l}$ desta solução foram adicionados à $100 \mathrm{ml}$ de tampão TBE (1x).

$\begin{array}{lc} & \text { 3.3.21. Solução de EDTA } \mathbf{0 , 5 M} \\ \text { EDTA } & 37,22 \mathrm{~g} \\ \mathrm{H}_{2} \mathrm{O} & 200 \mathrm{ml} \\ & \mathrm{O} \text { pH foi ajustado para } 7,5 \text { com pastilhas de } \mathrm{NaOH} .\end{array}$

\subsubsection{Solução de $\mathrm{NaCl} 5 \mathrm{M}$}

$\mathrm{NaCl}$

$58,44 \mathrm{~g}$

$\mathrm{H}_{2} \mathrm{O}$

$200 \mathrm{ml}$

\subsubsection{Solução salina $0.85 \% \mathrm{p} / \mathrm{v}$}

$\mathrm{NaCl}$

$8,5 \mathrm{~g}$

Água destilada

$1000 \mathrm{ml}$

Foram distribuídos $9 \mathrm{ml}$ por frasco, os quais foram autoclavados a $120^{\circ} \mathrm{C}(1,0 \mathrm{~atm})$, por 20 minutos e mantidos em refrigerador a $4^{\circ} \mathrm{C}$.

\subsubsection{Tampão da amostra $(6 \mathrm{x})$}

Azul de bromofenol

Ficoll

$\mathrm{H} 2 \mathrm{O}$
$250 \mathrm{mg}$

$15 \mathrm{~g}$

$100 \mathrm{ml}$

3.3.25. Tampão de corrida TEB (10x)

Trizma base $\mathrm{pH} 8.0$

Ácido bórico $\left(\mathrm{H}_{3} \mathrm{BO}_{3}\right)$

EDTA

$\mathrm{H} 2 \mathrm{O}$
$54,0 \mathrm{~g}$

$27,5 \mathrm{~g}$

$4,65 \mathrm{~g}$

$500 \mathrm{ml}$

A solução foi autoclavada e guardada à temperatura ambiente. No momento do uso, foi diluída (1:10) com água Milli Q. 


\subsubsection{Tampão fosfato, $\mathrm{pH} 6,8$ a 7,2}

Solução A:

$\mathrm{Na}_{2} \mathrm{HPO}_{4} \cdot 12 \mathrm{H}_{2} \mathrm{O}$

Água destilada

$3,73 \mathrm{~g}$

Solução B:

$\mathrm{KH}_{2} \mathrm{PO}_{4}$

Água destilada

$1000 \mathrm{ml}$

$2,40 \mathrm{~g}$

$1000 \mathrm{ml}$

No momento do uso, a cada 7 partes da solução $A$ foram adicionadas 3 partes da solução B.

\subsubsection{Tampão da Taq-DNApolimerase (RAPD-PCR)}

Este tampão foi adquirido da Pharmacia, na concentração $10 \mathrm{x}$ e é composto por $500 \mathrm{mM}$ de $\mathrm{KCl}, 15 \mathrm{mM} \mathrm{MgCl}_{2}$ e $100 \mathrm{mM}$ de Tris- $\mathrm{HCl}(\mathrm{pH}=9,0)$.

\subsubsection{Tampão de Extração de DNA (TEN)}

Tris- $\mathrm{HCl}(\mathrm{pH}=8,0)$

EDTA $(\mathrm{pH}=8,0)$

$\mathrm{NaCl}$
$10 \mathrm{mM}$

$10 \mathrm{mM}$

$15 \mathrm{mM}$

\subsection{Caracterização das Culturas de Bactérias Isoladas}

A caracterização de bactérias foi realizada pelo método clássico de identificação, havendo entretanto, métodos mais avançados e mais rápidos. Entretanto é muito importante salientar que todas as etapas da caracterização são igualmente imprescindíveis na caracterização do microrganismo. As amostras de plantas de milho foram submetidas às seguintes fases principais de caracterização pelo método clássico:

- diluição das amostras coletadas de folhas de plantas de milho;

- semeadura e isolamento das colônias;

- testes de morfologia;

- testes bioquímicos. 


\subsubsection{Isolamento de Colônias de Bactérias}

Cada explante foliar $(2 \times 4 \mathrm{~cm})$ de milho, foi dividido em cinco partes e submetido a uma bateria de soluções para assepsia externa. Lavagem em solução de álcool $70 \% \mathrm{v} / \mathrm{v}$ durante um minuto; seguida de lavagem em solução de $\mathrm{NaOCl}$ $3 \% \mathrm{v} / \mathrm{v}$, durante quatro minutos e finalmente solução de álcool $70 \% \mathrm{v} / \mathrm{v}$, por 30 segundos (Pereira, 1993).

Foram então distribuídos em placas de Petri contendo $20 \mathrm{ml}$ de meio de cultura e as placas incubadas durante no mínimo 72 horas a $37^{\circ} \mathrm{C}$ no meio TSA (item 3.2.2).

\subsubsection{Diluição das Amostras de Culturas Isoladas de Plantas de}

Milho

Pipetou-se $0,1 \mathrm{ml}$ da amostra e transferiu-se para um tubo contendo 10 $\mathrm{ml}$ de solução salina a $0,2 \%$ (Ringer $1 / 4$ ).(Diluição $10^{-2}$ ). Deste tubo pipetou-se $1 \mathrm{ml}$ e transferiu-se para outro tubo contendo $10 \mathrm{ml}$ de diluente (diluição $10^{-3}$ ), e assim sucessivamente até a diluição $10^{-5}$. Foram semeados $1 \mathrm{ml} \mathrm{e} 0,1 \mathrm{ml}$ da diluição $10^{-5}$, obtendo assim, as diluições $10^{-5}$ e $10^{-6}$ em placa, respectivamente. A semeadura foi feita em duplicata em meio NA, para a recuperação das bactérias. A incubação foi feita a $37^{\circ} \mathrm{C}$, por 24 horas. As colônias assim obtidas foram inoculadas em tubos contendo NA para posterior caracterização através de métodos de coloração e bioquímicos.

\subsubsection{Purificação de Colônias de Bactérias}

Placas contendo contagem de unidades formadoras de colônias (UFC) menores que 300 colônias foram utilizadas para o isolamento, tendo-se como critério as características morfológicas e microscópicas distintas. As colônias assim selecionadas sofreram a purificação por estrias de esgotamento, no mesmo meio de cultura em que foi semeada, e depois incubadas à temperatura de semeadura. Após o crescimento, colônias isoladas foram repicadas em tubos contendo meio (item 3.2.1), inclinado para a manutenção e testes.

As culturas isoladas e purificadas foram submetidas aos testes bioquímicos e morfológicos. 


\subsubsection{Testes Morfológicos}

\subsubsection{Morfologia em meio sólido}

As colônias foram observadas sob microscópio estereoscópico CARL ZEISS (JENA-CITOVAL 2), e anotadas suas características principais, relativas a: forma, superficie, borda, elevação, pigmentação, consistência e odor, verificando a presença de colônias contaminantes através da coloração, forma e superfície diferentes. Para as colônias que apresentaram contaminação, uma nova etapa de purificação foi realizada.

\subsubsection{Morfologia - microscopia}

A microscopia ótica (Microscópio modelo OLYMPUS-TOKYO BH2) foi utilizada para a observação das células bacterianas, em sua forma, mobilidade, arranjo, tamanho e presença de uma série de características importantes para a discriminação dos diferentes grupos de bactérias. A técnica de coloração utilizada foi a Coloração de Gram, visando a diferenciação dos grupos microbianos durante a caracterização preliminar, aliada à observação de células a fresco (montagem úmida).

\subsection{Coloração de Gram}

Foi feito um esfregaço fino de células, fixado pelo calor e corado sucessivamente por uma solução de cristal violeta (ítem 3.3.4), foi então fixado com uma solução diluída de iodo (ítem 3.3.2). Posteriormente o esfregaço foi tratado com um solvente orgânico (álcool) e contra-corado com um corante de contraste vermelho (safranina, ítem 3.3.3).

Ao ser tratado com álcool, algumas células são rapidamente descoradas (gram negativas) e outras são resistentes à ele (gram positivas). As células gram positivas retém a cor violeta intensa, determinada pela coloração inicial de cristal violeta e iodo, enquanto as células gram negativas tomam a coloração vermelha do contraste.

\subsection{Montagem Úmida:}

Foi preparada uma lâmina com uma gota de caldo ou água esterilizada, e de uma alçada fina do inóculo em questão. Introduziu-se uma lamínula de forma a não formar bolhas, pressionando levemente contra o líquido. 
Usando-se este tipo de lâmina foi possível observar as células vivas, em tamamho normal, o que permitiu verificar mobilidade, e observação de outras estruturas, quando presentes.

\subsubsection{Testes Bioquímicos}

\subsubsection{Esculina}

Com o auxílio de uma agulha, retirou-se uma grande quantidade de inóculo da cultura pura, com 24 horas de crescimento. Em seguida, foram feitas picadas na placa de esculina-ágar (ítem 3.2.3), deixando espaço suficiente entre uma picada e outra para que fosse possível a visualização da formação de um halo. Incubou-se a placa a $35^{\circ} \mathrm{C}$ e fizeram-se observações diárias, até obtenção de um halo escuro em torno da colônia, determinando resultado positivo. O resultado foi considerado negativo quando não houve formação de halo.

\subsubsection{Arginina, Lisina e Ornitina descarboxilase}

Inoculou-se uma cultura de 18 a 24 horas de cultivo, em um tubo contendo caldo nutriente (ítem 3.2.1) e o respectivo aminoácido (arginina, ornitina ou lisina), e este tubo foi selado com ágar $(2 \% \mathrm{p} / \mathrm{v})$ esterilizado, uma vez que a reação somente ocorre em anaerobiose. Incubou-se o tubo a $35^{\circ} \mathrm{C}$, juntamente com um tubo controle, sem o inóculo. Fizeram-se leituras diárias, a cada 24 horas durante 4 dias. O resultado foi positivo, quando o meio se tornou violeta, devido à utilização do aminoácido e alcalinização. $\mathrm{O}$ meio amarelo indicou resultado negativo.

\subsubsection{Hidrólise da Caseína}

$\mathrm{Na}$ placa de meio contendo leite desnatado (ítem 3.2.5), fizeram-se picadas da cultura, com o auxílio de uma agulha. Incubou-se a $30^{\circ} \mathrm{C}$, com leituras diárias, até $\mathrm{o}$ aparecimento de um halo transparente em torno das colônias (utilização da caseína), que determinou resultado positivo, e negativo quando não houve a formação de halo.

\subsubsection{Catalase}

Introduziu-se $1 \mathrm{ml}$ de água destilada em um tubo de ensaio. Com uma alça de platina retirou-se um inóculo pesado da cultura pura o qual foi adicionado na água destilada.Com uma pipeta Pasteur adicionaram-se cerca de 5 gotas $(0,3 \mathrm{ml})$ de 
$\mathrm{H}_{2} \mathrm{O}_{2}(3 \% \mathrm{v} / \mathrm{v})$. Não se agitou o tubo, para evitar um resultado falso positivo. $\mathrm{O}$ resultado foi positivo, quando do desprendimento de gás e negativo quando inerte.

\subsubsection{Citrato de Simmons}

Com a alça de platina colheu-se um pequeno inóculo da cultura pura, com 18 a 24 horas de crescimento. Espalhou-se o inóculo por toda a extensão do tubo contendo meio (ítem 3.2.6) e incubou-se a $37^{\circ} \mathrm{C}$ por 24 a 48 horas. Há ocasiões em que uma incubação mais prolongada pode ser necessária. Resultado positivo: azul (utilização de citrato como fonte de carbono) e negativo : verde (inerte)

\subsubsection{EPM}

Com o auxílio de uma agulha foi feita uma picada com inóculo, no meio inclinado até o fundo do tubo contendo meio (ítem 3.2.7) e em seguida espalhou-se o inóculo sobre toda a superfície inclinada. Incubou-se a $37^{\circ} \mathrm{C}$, com leituras diárias, ou até a obtenção da modificação de coloração dos indicadores. Os resultados foram determinados como a seguir:

amarelo/azul: fermentação da glicose

azul/amarelo: 1-triptofano desaminase

azul/azul: hidrólise de uréia

halo negro:formação de $\mathrm{H}_{2} \mathrm{~S}$

\subsubsection{Hidrólise da Gelatina}

Retiraram-se os tubos de meio com gelatina (ítem 3.2.8) do refrigerador somente no momento de inocular, para assegurar a solidificação do meio no momento de inóculo. Da cultura pura, com 18 a 24 horas, retirou-se com alça, uma grande quantidade de inóculo. $O$ tubo inoculado foi incubado junto a um tubo controle, à temperatura de $22-25^{\circ} \mathrm{C}$. Foram então realizadas leituras diárias, a partir de 24 horas até 14 dias. Observaram-se a turbidez e a liquefação. Ao fim de 24 horas,os tubos foram retirados da estufa e colocados no refrigerador por aproximadamente 2 horas. Este tempo é suficiente para determinar se houve a hidrólise da gelatina. Os tubos foram reincubados sem agitação, procedendo assim até ao fim de 14 dias. Considerou-se como resultado positivo a liquefação da gelatina, e negativo sua não liquefação. 


\subsubsection{Indol}

Inoculou-se com alça, uma pequena quantidade de inóculo em meio de indol (ítem 3.2.9). Incubou-se a $37^{\circ} \mathrm{C}$ e fez-se a leitura quando o crescimento (turbidez) no tubo estivesse forte. $\mathrm{O}$ tubo teste foi retirado do incubador, $\mathrm{e}$ adicionaram-se 6 a 8 gotas do Reativo de Kovac's. O resultado positivo foi dado pela formação de um halo vermelho a cor de rosa forte. Um halo amarelo indicou resultado negativo.

\subsubsection{MacConkey}

Estrias de esgotamento foram feitas na placa contendo meio (ítem 3.2.10) e estas incubadas a $37^{\circ} \mathrm{C}$. A leitura foi feita com base na avaliação do crescimento com ou sem a utilização da lactose. O crescimento da colônia neste meio identificou a bactéria como Gram negativo, e quando a colônia apresentou coloração violeta foi considerada lactase positiva.

\subsubsection{Redução de Nitrato a Nitrito}

Uma alçada da cultura foi inoculada, por 18 a 24 horas em tubo teste de nitrato (ítem 3.2.11). Incubou-se a $30^{\circ} \mathrm{C}$ por 24 horas ou até que a cultura apresentasse um crescimento moderado. A leitura foi feita após a adição de 6 a 8 gotas da mistura volumétrica das soluções $\mathrm{A}$ e $\mathrm{B}($ Ver ítem 3.3.8). Os resultados foram determinados como a seguir:

Positivo: formação de halo vermelho

Negativo: inalterado (mesmo com a adição de $\mathrm{Zn}$ )

\subsubsection{O/F (Hugh Lefson)}

Fez-se uma picada até o fundo do meio contido em tubos (ítem 3.2.12), sendo um dos tubos vedado com ágar a $2 \%$. Incubou-se a $37^{\circ} \mathrm{C}$ e fizeram-se leituras diárias por um período de 1 a 2 semanas. Para o tubo aberto foram considerados os resultados: Oxidativo, quando o meio apresentou coloração amarela, Fermentativo, quando o meio não modificou sua cor, e Inerte, quando não houve mudança de cor ou com cor azulada. Para o tubo fechado: Oxidativo, sem mudança da cor do meio, Fermentativo, quando de cor amarela, e Inerte, quando não modificou a coloração. 


\subsubsection{Tioglicolato}

Colocou-se o tubo contendo o meio de tioglicolato (ítem 3.2.13) em água fervente até que a camada de tom róseo, devida a rezasurina oxidada,se desfizesse. Com o auxílio de uma agulha, retirou-se uma quantidade do inóculo ativo. Fez-se uma picada até o fundo do meio, no tubo de tioglicolato, rosqueando rapidamente o tubo, evitando-se desta forma, o contato com o ar. A leitura foi realizada assim que se obteve um crescimento significativo. Os resultados foram determinados como a seguir:

- crescimento somente na superfície - aeróbio estrito

- crescimento em toda a extensão - anaeróbio facultativo

- crescimento somente no fundo - anaeróbio estrito

\subsubsection{TSI Triple Sugar Iron}

Com a agulha, tocou-se o centro da colonia pura e isolada. Introduziuse a agulha contendo o inóculo até o fundo do meio em tubo teste (ítem 3.2.14), e posteriormente espalhou-se sobre a superficie do meio inclinado. Incubaram-se os tubos a $35^{\circ} \mathrm{C}$, e procedeu-se a leitura dos resultados em 18 ou no máximo 24 horas após. Foram analisados a base e o ápice do tubo inoculado, e observaram-se as diferenças de coloração resultantes da variação no $\mathrm{pH}$ e a consequente resposta do indicador. Os resultados foram determinados como a seguir:

$\begin{array}{lll}\text { superfície } & \text { base } & \text { resultado } \\ \text { amarelo } & \text { amarela } & \text { ácido/ácido } \\ \text { vermelho } & \text { amarela } & \text { alcalino/ácido } \\ \text { vermelho } & \text { vermelha } & \text { alcalino/alcalino } \\ \text { vermelho } & \text { inerte } & \text { alcalino/inerte }\end{array}$

\subsubsection{Vermelho de metila}

Foi inoculada com alça uma grande quantidade da cultura em três tubos contendo o meio base para o teste (ítem 3.2 .15 ). Incubou-se a $30^{\circ} \mathrm{C}$ e fizeramse leituras em 3, 5 e 7 dias, sendo o teste feito em triplicata. Para a leitura, colocaram-se de 5 a 7 gotas do indicador Vermelho de Metila. Os resultados foram determinados como a seguir: positivo: halo vermelho na superfície do caldo e negativo: ausência de halo. 


\subsubsection{Voges Proskauer}

Foi inoculada uma alçada da cultura no tubo contendo o meio teste (ítem 3.2.15), e incubou-se a $30^{\circ} \mathrm{C}$. Fizeram-se leituras em 3, 5 e 7 dias. $\mathrm{Na}$ ocasião da leitura, adicionaram-se 6 gotas de alfa-naftol e 2 gotas de $\mathrm{KOH}$. Os resultados foram determinados como a seguir: positivo: halo vermelho e negativo: ausência de halo

\subsubsection{Oxidase}

Com o auxílio da alça, espalhou-se a cultura sobre um disco de papel de filtro e colocaram-se duas gotas do reagente (ítem 3.3.7), sobre a superfície do disco. O surgimento de coloração azul escura após 30 segundos indicou resultado positivo.

\subsubsection{Motilidade}

A motilidade foi observada semeando-se as bactérias em tubos camada alta de meio semi-sólido SIM (ítem 3.2 .16 ), e incubadas a $20^{\circ} \mathrm{C}$, quando foram observadas zonas túrbidas ao redor da inoculação, considerou-se o resultado como positivo.

\subsubsection{MILI (motilidade, indol-lisina)}

As culturas foram semeadas com agulha, até o fundo do meio contido nos tubos. Neste meio (ítem 3.2.17), foi possível detectar a presença de flagelos na bactéria,caracterizada por zonas túrbidas ao redor da picada. A capacidade de produzir indol a partir do triptofano,verificada após 18-24 horas de cultura, foi feita adicionando-se no tubo de cultura 3-5 gotas do Reativo de Kovac's(ítem 3.3.6), e quando observou-se o aparecimento de uma coloração vermelho-violeta, o resultado foi considerado positivo. A presença da enzima lisina descarboxilase foi determinada da seguinte forma: meio arroxeado significando lisina descarboxilase positivo e meio amarelo indicando lisina descarboxilase negativo.

\subsubsection{Uréia}

Foi inoculada uma alçada da cultura no tubo contendo o meio teste (ítem 3.2.18), e incubou-se a $37^{\circ} \mathrm{C}$. Fizeram-se leituras em $8,12,24$ e 48 horas. Reação positiva: cor vermelha e negativa:inalterada. 


\subsubsection{Egg Yolk}

Foram inoculadas algumas picadas na placa contendo o meio Bactoegg yolk (ítem 3.2.19), e incubou-se a $37^{\circ} \mathrm{C}$. Foi verificado após 24 horas, o aparecimento de um halo branco, farináceo, em torno das inoculações das culturas indicando resultado positivo.

\subsection{Teste Antagonístico: Fungos X Bactérias Endofíticas}

\subsubsection{Método de inoculação em placa}

Os fungos foram semeados, com auxilio de uma alça de platina, formando uma estria reta no centro da placa de Petri contendo aproximadamente 20 $\mathrm{ml}$ de meio NA e cultivados a $28^{\circ} \mathrm{C}, 3-7$ dias. Após esse período, o qual variou entre as linhagens de fungos, as bactérias foram semeadas em estrias transversais aos fungos. $\mathrm{O}$ crescimento das colônias de bactérias foi anotado após 24 horas, a $28^{\circ} \mathrm{C} \mathrm{e}$ a temperatura ambiente.

\subsection{Análise da Variabilidade Genética dos isolados por RAPD}

\subsubsection{Extração de DNA}

As bactérias foram crescidas em $100 \mathrm{ml}$ de $\mathrm{CN}$ (ítem 3.2.1), sob agitação (200 RPM) por 18 horas (over night). Em seguida, centrifugou-se a cultura de bactérias por 5 ' a 6000 RPM (4303g), em tubos e desprezou-se o sobrenadante. Ressuspendeu-se o pelet em $4 \mathrm{ml}$ de TEN(ítem 3.3.29), contendo lisozima (4mg/ml) e incubou-se por $30-45$ minutos a $37^{\circ} \mathrm{C}$. Adicionou-se então, $8 \mu \mathrm{l}$ de RNAse $(25 \mathrm{mg} / \mathrm{ml})($ ítem 3.3 .19$)$ e incubou-se por $15^{\prime}$ em temperatura ambiente. Acrescentou-se $580 \mu \mathrm{l}$ de $\operatorname{SDS}(8,45 \% \mathrm{v} / \mathrm{v})$ e incubou-se a $75^{\circ} \mathrm{C}$ até a solução se tornar clara (transparente). Acrescentou-se, em seguida $2,5 \mathrm{ml}$ de acetato de sódio( $3 \mathrm{M} ; \mathrm{pH} 5,2)$ e incubou-se por $20^{\prime}$ em gelo, e logo em seguida acrescentou-se um volume de clorofane(ítem 3.3.11) e agitou-se o tubo, suavemente por inversão. Centrifugou-se a 4000 RPM (1912g) por $15^{\prime}$.Após esta centrifugação, retirou-se o sobrenadante e acrescentou-se um volume de clorofil (ítem 3.3.12), agitou-se o tubo suavemente por inversão e centrifugou-se a 4000 RPM (1912g) por 15'. Retirou-se o sobrenadante e repetiu-se o processo com clorofil. Por último, retirou-se o sobrenadante e acresentou-se dois volumes de etanol gelado e esperou-se a precipitação do material, este processo foi realizado a $-20^{\circ} \mathrm{C}$ (over-night). Após a precipitação, centrifugou-se a 12.000 RPM (17.210g) por 20', eliminou-se o 
secagem dos tubos a temperatura ambiente, o DNA foi solubilizado em $500 \mu \mathrm{d}$ de TEN (item 3.3.29).

\subsubsection{Amplificação do DNA ( Reação de PCR)}

Após a realização de um ensaio de otimização da técnica (Williams et al., 1990), cujos resultados se encontram descritos no item 4.4.1., foram estabelecidas as seguintes condições de amplificação:

PCR Buffer 10 x (GIBCO-BRL) $\mathbf{2 , 5} \boldsymbol{\mu l}(\mathbf{1 x})$

Sol. $\mathrm{MgCl}_{2}(50,0 \mathrm{mM})$

$2,5 \mu \mathrm{I}(5,0 \mathrm{mM})$

dNTP's $(2,5 \mathrm{mM})$

$2,0 \mu \mathrm{l}(200 \mathrm{uM})$

oligonucleotídio $(4,0 \mathrm{mM})$

$2,5 \mu \mathrm{l}(0,4 \mathrm{mM})$

DNA genômico

$2,5 \mu l(5,0 \mathrm{ng})$

Taq-DNApolimerase

$\mathbf{0 , 3} \mu \mathrm{I}(\mathbf{2 , 0 U})$

$\mathrm{H}_{2} \mathrm{O}$ Mili-Q autoclavada

$12,7 \mu 1$

óleo mineral

1 gota

O termociclador utilizado para a reação foi Perkin-Elmer-Cetus (Gene Amp PCR System), iniciada por denaturação por 4 minutos a $92^{\circ} \mathrm{C}$, seguida de 40 ciclos de 1 minuto cada a $92^{\circ} \mathrm{C}, 1$ minuto e 30 segundos a $37^{\circ} \mathrm{C}$ e 2 minutos a $72^{\circ} \mathrm{C}$, completando-se com 1 ciclo de 3 minutos a $72^{\circ} \mathrm{C}$. A sequência e conteúdo de bases CG dos oligonucleotídios utilizados se encontram na Tabela 3.6.1.

\subsubsection{Análise de Polimorfismo}

Os produtos de amplificação foram separados por eletroforese (3 $\mathrm{V} / \mathrm{cm}$ ) em gel de agarose 1,5\% (ítem 3.3.17) e posteriormente corados por 15 minutos com brometo de etídio (ítem 3.3.20). Por ser este um agente intercalante, o DNA pode ser evidenciado e fotografado sob luz UV em transiluminador. O DNA de lambda clivado com Hind III, foi utilizado como marcador de peso molecular.

A análise da variabilidade genética foi realizada pelo agrupamento das linhagens segundo os princípios adotados em taxonomia numérica. Utilizou-se o coeficiente de similaridade Jaccard, que permite calcular similaridades com base em variáveis binárias ( 0 para ausência e 1 para presença de banda). As bandas foram consideradas como variáveis enquanto as linhagens como unidades. $O$ coeficiente foi calculado segundo a fórmula $J=M / P$, onde $M$ é o número de concordâncias 
positivas, e P o número total de variáveis, menos concordâncias negativas (Sneath \& Sokal, 1973).

Desta forma, o coeficiente $\mathrm{J}$ leva em conta apenas as discordâncias e as concordâncias positivas, quanto a presença ou ausência de bandas, desconsiderando as concordâncias negativas. Quanto maior a semelhança entre duas linhagens, maior é o valor do coeficiente de similaridade. As unidades foram agrupadas através do método UPGMA (Unweighted Pair-Group Method with Arithmetical Average), que é um modelo de agrupamento hierárquico, que permite a construção de dendrogramas (Sneath \& Sokal, 1973). Matrizes e dendrogramas foram elaborados com auxílio do programa NTSYS-PC (Rohlf, 1988).

Tabela. 3.6.1. Sequência de nucleotídios no sentido $5^{\prime} \rightarrow 3^{\prime}$, e conteúdo de bases CG dos cinco oligonucleotídios selecionados e utilizados para amplificação.

\begin{tabular}{lll}
\hline Oligonucleotídio & sequência 5'---3 & Conteúdo CG(\%) \\
\hline OPX07 & GAGCGAGGCT & 70 \\
\hline OPE02 & GGTGCGGGAA & 70 \\
\hline OPE11 & GAGTCTCAGG & 60 \\
\hline OPE12 & TTATCGCCCC & 60 \\
\hline OPE14 & TGCGGCTGAG & 70 \\
\hline
\end{tabular}

\subsection{Análises estatísticas}

Os dados de número de colônias nas três populações estudadas foram obtidos de dois experimentos idênticos realizados em dois locais diferentes. Cada um desses experimentos fora instalado no delineamento inteiramente casualizado e consistiu de 24 tratamentos dados pela combinação de 12 genótipos de plantas de milho com duas épocas de coleta, sendo que desses 12 genótipos, três foram provenientes da população 1 , três da população 2 e seis da população de híbridos simples, oriundos do cruzamento das populações 1 e 2 , tratando-se portanto de um fatorial $12 \times 2$ com classificação hierárquica para o fator genótipo dentro da população.

Adotando-se a teoria de modelos lineares generalizados, a análise estatística foi realizada no GLIM 4.0 ("Generalized Linear Interactive Modelling 
System", versão 4.0), considerando-se o modelo Poisson com ligação logarítimica para a análise conjunta e para a análise individual referente ao local 1. Para a análise individual referente ao local 2 foi utilizado o modelo binomial negativo com ligação canônica e parâmetro de dispersão fixo e igual a 2. Os efeitos das fontes de variação do modelo foram testados pelo Teste de Qui-quadrado para as suas respectivas "deviances".

A "deviance"é uma estatística que mede a contribuição de determinada fonte de variação do modelo dada a variação total contida nos dados. Essa estatística tem, assintaticamente, distribuição de $\mathrm{X}_{\mathrm{v}}{ }_{\mathrm{v}}$, onde $\mathrm{v}$ é o número de graus de liberdade calculado associado à fonte de variação considerada. 


\section{RESULTADOS E DISCUSSÃO}

\subsection{Isolamento e frequência de infecção das plantas de milho}

$\mathrm{Na}$ Figura 4.1 observa-se aspectos do isolamento das colônias de bactérias endofíticas de explantes de folhas de milho, em meio de cultura. Foram isoladas desta forma, no total, 169 colônias de bactérias endofíticas (Tabela 4.1), de folhas das populações de plantas de milho BR-105 (P1), BR-106 (P2) e população de híbridos simples ( $\mathrm{P} 1 \mathrm{x} 2)$, entre $\mathrm{P} 1$ e P2, em dois experimentos idênticos cujos respectivos tratamentos se encontram nas Tabelas 4.2 e 4.3 , realizados em dois locais distintos (ítem 3.1.2), com o intuito de verificar a ocorrência de bactérias endofíticas na cultura de milho, nestes locais, e ainda detectar diferenças devidas à fase de desenvolvimento dos hospedeiros, abordada pelas duas coletas realizadas em diferentes épocas de cultivo. As três populações hospedeiras encontram-se descritas no ítem 3.1.1.

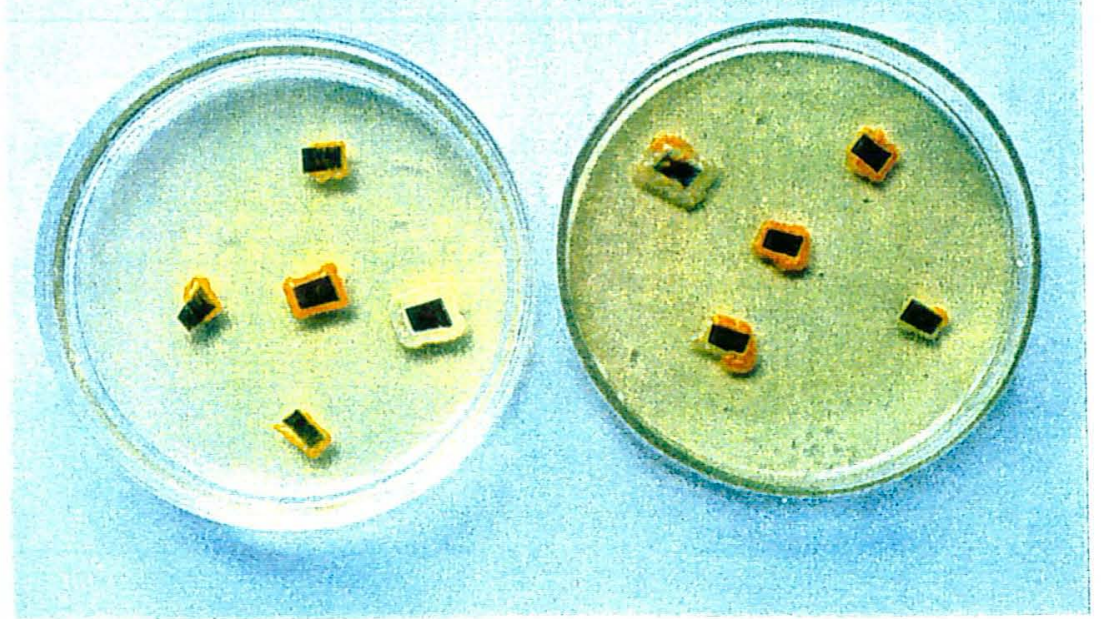

Figura 4.1. Aspectos do isolamento de bactérias endofíticas de folhas de milho (Zea mays). Observar o crescimento de colônias de bactérias de morfologia e coloração diferenciadas no meio de cultura, ao redor dos fragmentos de folhas de milho. 
O número de colônias de bactérias endofíticas foi diferente entre os dois locais, o que pode ser observado na Figura 4.2, e de acordo com o teste de $\mathrm{X}^{2}$ para "deviance" da interação entre tratamentos e locais (ítem 3.7), essa diferença foi significativa a nível de $1 \%$ de probabilidade (Tabela 4.4-A). Os diferentes tratamentos assim como os valores das médias para os mesmos são dados nas Tabelas 4.2 e 4.3. Dentre os fatores que poderiam estar influenciando essa diferença pode-se destacar alguns fatores ambientais, tais como diferenças climáticas, referentes a macroclima e microclimas, assim como variações edáficas, além dos fatores genotípicos dos hospedeiros e endófitos.

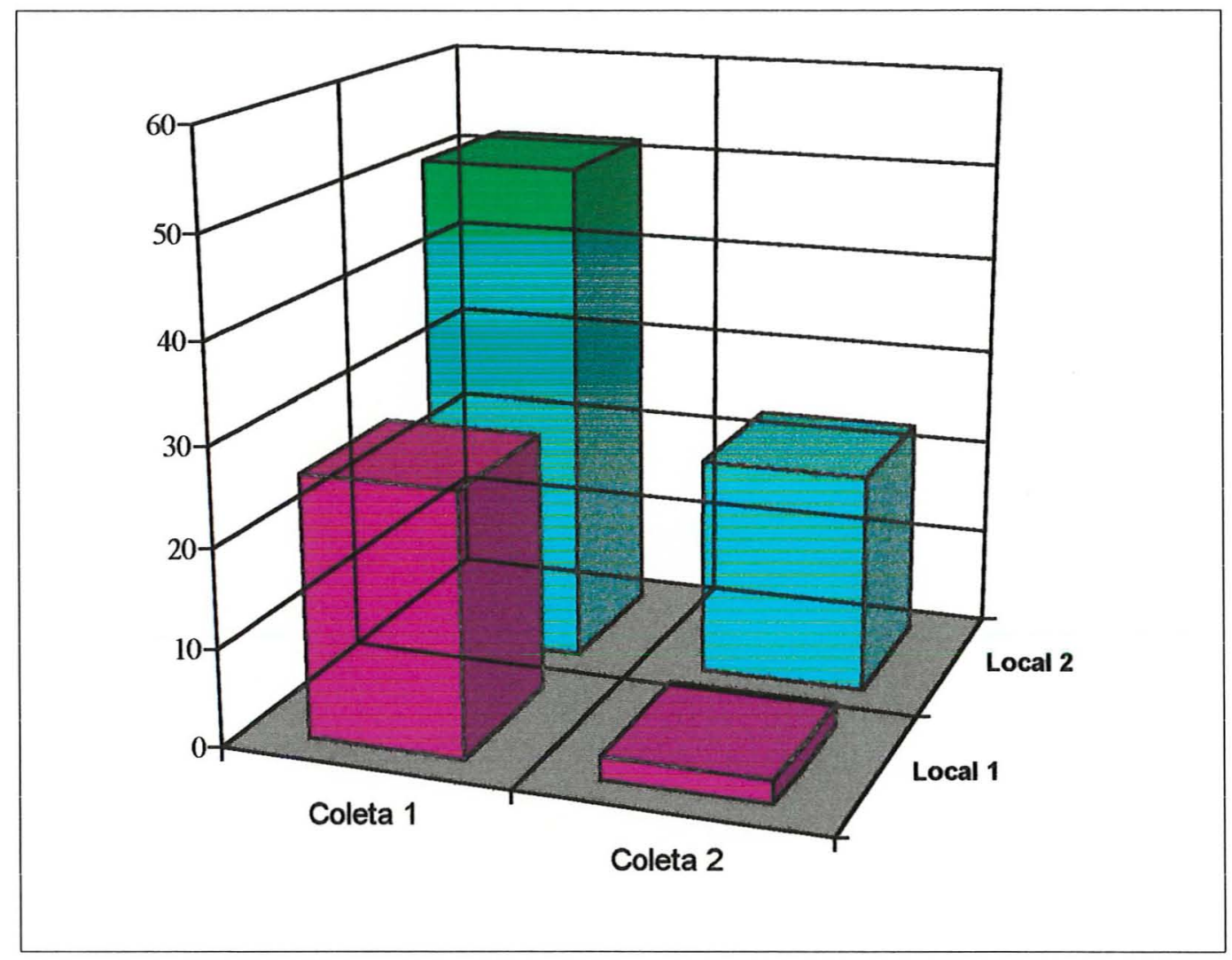

Figura 4.2. Gráfico representativo das percentagens relativas de ocorrência de bactérias endofíticas em três populações de milho em duas coletas, em dois locais. Legendas: Local 1= Fazenda Areião; Local 2= Caterpillar (Áreas experimentais do Depto Genética ESALQ/USP); Coleta 1= Nov/93 (6,5 semanas de cultivo), Coleta 2= Dez/93 (10 semanas de cultivo). Ocorrência total de 169 colônias. 
Tabela 4.1. Número de colônias de bactérias endofíticas isoladas de folhas de plantas de milho em três populações. Legendas: $\mathrm{P} 1=\mathrm{BR}-105$; $\mathrm{P} 2=\mathrm{BR}-106 ; \mathrm{P} 1 \times 2=$ híbridos simples entre $\mathrm{P} 1$ e P2. Local 1= Areião; Local $2=$ Caterpillar; Coleta $1=6,5$ semanas de cultivo; Coleta $2=10$ semanas de cultivo.

\begin{tabular}{|l|l|l|l|l|l|l|}
\cline { 2 - 7 } \multicolumn{1}{c|}{} & \multicolumn{3}{l|}{ LOCAL 1 } & \multicolumn{3}{l|}{ LOCAL 2 } \\
\hline & P1 & P2 & P1x2 & P1 & P2 & P1x2 \\
\hline Coleta 1 & 03 & 26 & 11 & 21 & 26 & 40 \\
\hline Coleta 2 & 00 & 03 & 01 & 01 & 29 & 08 \\
\hline
\end{tabular}

Contudo, as duas áreas experimentais situam-se na mesma região, distando entre si por um raio de aproximadamente $10 \mathrm{Km}^{2}$, o que descartaria a possibilidade de grandes variações climáticas influenciando em tais resultados. Entretanto, o mesmo não ocorre com relação aos fatores edáficos, visto que os tipos de solo das duas áreas experimentais são diferentes como descrito no ítem 3.1.2.

Tabela 4.2. Médias do número de colônias para cada tratamento, considerando-se três repetições, no Local 1 (Areião). Legendas: P1=BR-105, P2=BR-106, P1x2=híbridos simples entre P1 e P2.

\begin{tabular}{|c|c|c|c|c|}
\hline População & Genótipo & Coleta $^{*}$ & Tratamento & Media \\
\hline $\mathrm{PI}$ & $05.17 .1 \mathrm{~A}$ & 1 & 1 & 0,00 \\
\hline$\overline{\mathrm{PI}}$ & $05.17 .1 \mathrm{~A}$ & 2 & 2 & 0,00 \\
\hline P1 & $05.01 .4 \mathrm{~B}$ & 1 & 3 & 0,33 \\
\hline P1 & $05.01 .4 \mathrm{~B}$ & 2 & 4 & 0,00 \\
\hline P1 & $05.05 .2 \mathrm{~A}$ & 1 & 5 & 0,66 \\
\hline P1 & $05.05 .2 \mathrm{~A}$ & 2 & 6 & 0,00 \\
\hline $\mathrm{P} 2$ & $06.06 .3 \mathrm{~A}$ & 1 & 7 & 5,00 \\
\hline $\mathrm{P} 2$ & $06.06 .3 \mathrm{~A}$ & 2 & 8 & 0,00 \\
\hline $\mathrm{P} 2$ & $06.08 .1 \mathrm{~A}$ & $\mathrm{I}$ & 9 & 1,33 \\
\hline $\mathrm{P} 2$ & $06.08 .1 \mathrm{~A}$ & 2 & 10 & 0,66 \\
\hline P2 & $06.03 .5 \mathrm{~B}$ & 1 & 11 & 2,33 \\
\hline P2 & $06.03 .5 \mathrm{~B}$ & 2 & 12 & 0,33 \\
\hline P1X2 & $18.1 \times 1.4$ & 1 & 13 & 0,66 \\
\hline $\mathrm{P} 1 \mathrm{X} 2$ & $18.1 \times 1.4$ & 2 & 14 & 0,00 \\
\hline $\mathrm{P} 1 \mathrm{X} 2$ & $8.2 \times 33.5$ & 1 & 15 & 1,66 \\
\hline P1X2 & $8.2 \times 33.5$ & 2 & 16 & 0,33 \\
\hline $\mathrm{P} 1 \mathrm{X} 2$ & $3.5 \times 18.6$ & 1 & 17 & 0,00 \\
\hline $\mathrm{P} 1 \mathrm{X} 2$ & $3.5 \times 18.6$ & 2 & 18 & 0,00 \\
\hline $\mathrm{P} 1 \mathrm{X} 2$ & $24.7 \times 05.2$ & 1 & 19 & 0,00 \\
\hline P1X2 & $24.7 \times 05.2$ & 2 & 20 & 0,00 \\
\hline P1X2 & $44.1 \times 23.2$ & 1 & 21 & 0,66 \\
\hline $\mathrm{P} 1 \mathrm{X} 2$ & $44.1 \times 23.2$ & 2 & 22 & 0,00 \\
\hline $\mathrm{P} 1 \mathrm{X} 2$ & $37.5 \times 19.1$ & 1 & 23 & 0,66 \\
\hline $\mathrm{P} 1 \mathrm{X} 2$ & $37.5 \times 19.1$ & 2 & 24 & 0,00 \\
\hline
\end{tabular}

*Coleta $1=6,5$ semanas de cultivo; Coleta $2=10$ semanas de cultivo. 
Tabela 4.3. Médias do número de colônias para cada tratamento, considerando-se três repetições, no Local 2 (Caterpillar). Legendas: P1=BR-105, P2=BR-106, P1×2=híbridos simples entre P1 e P2.

\begin{tabular}{|c|c|c|c|c|}
\hline População & Genótipo & Coleta & Tratamento & Media \\
\hline P1 & $05.17 .1 \mathrm{~A}$ & 1 & 1 & 1,66 \\
\hline $\mathrm{P} 1$ & $05.17 .1 \mathrm{~A}$ & 2 & 2 & 0,00 \\
\hline P1 & $05.01 .4 \mathrm{~B}$ & 1 & 3 & 2,33 \\
\hline P1 & $05.01 .4 \mathrm{~B}$ & 2 & 4 & 0,00 \\
\hline P1 & $05.05 .2 \mathrm{~A}$ & 1 & 5 & 3,00 \\
\hline $\mathrm{PI}$ & $05.05 .2 \mathrm{~A}$ & 2 & 6 & 0,33 \\
\hline $\mathrm{P} 2$ & $06.06 .3 \mathrm{~A}$ & 1 & 7 & 1,66 \\
\hline $\mathrm{P} 2$ & $06.06 .3 \mathrm{~A}$ & 2 & 8 & 4,33 \\
\hline P2 & $06.08 .1 \mathrm{~A}$ & 1 & 9 & 3,33 \\
\hline $\mathrm{P} 2$ & $06.08 .1 \mathrm{~A}$ & 2 & 10 & 4,33 \\
\hline $\mathrm{P} 2$ & $06.03 .5 \mathrm{~B}$ & 1 & 11 & 3,66 \\
\hline P2 & $06.06 .5 \mathrm{~B}$ & 2 & 12 & 1,00 \\
\hline P1X2 & $18.1 \times 1.4$ & 1 & 13 & 0,33 \\
\hline $\mathrm{P} 1 \mathrm{X} 2$ & $18.1 \times 1.4$ & 2 & 14 & 0,66 \\
\hline $\mathrm{P} 1 \mathrm{X} 2$ & $8.2 \times 33.5$ & 1 & 15 & 3,00 \\
\hline $\mathrm{P} 1 \mathrm{X} 2$ & $8.2 \times 33.5$ & 2 & 16 & 0,66 \\
\hline $\mathrm{P} 1 \mathrm{X} 2$ & $3.5 \times 18.6$ & 1 & 17 & 3,33 \\
\hline $\mathrm{P} 1 \mathrm{X} 2$ & $3.5 \times 18.6$ & 2 & 18 & 0,33 \\
\hline $\mathrm{P} 1 \mathrm{X} 2$ & $24.7 \times 05.2$ & 1 & 19 & 4,33 \\
\hline P1X2 & $24.7 \times 05.2$ & 2 & 20 & 1,00 \\
\hline $\mathrm{P} 1 \mathrm{X} 2$ & $44.1 \times 23.2$ & 1 & 21 & 2,33 \\
\hline $\mathrm{P} 1 \mathrm{X} 2$ & $44.1 \times 23.2$ & 2 & 22 & 0,00 \\
\hline $\mathrm{P} 1 \mathrm{X} 2$ & $37.5 \times 19.1$ & 1 & 23 & 0,00 \\
\hline $\mathrm{P} 1 \mathrm{X} 2$ & $37.5 \times 19.1$ & 2 & 24 & 0,00 \\
\hline
\end{tabular}

*Coleta $1=6,5$ semanas de cultivo; Coleta $2=10$ semanas de cultivo.

Tabela 4.4 (A, B, C, D, E). Análise de "deviance" da ocorrência de bactérias endofíticas em folhas de plantas de milho (Zea mays L.), nas populações P1, P2 e P1x2. Local 1= Areião; Local 2= Caterpillar.

4.4-A. Análise de "deviance para o número de colônias considerando-se os dois locais.

\begin{tabular}{lcc}
\hline CV & GL & "Deviance" \\
\hline Local & 1 & 40,46 \\
\hline Tratamento (Trat) & 23 & 150,70 \\
\hline Trat $x$ Local & 23 & $62,36^{* *}$ \\
\hline Resíduo & 96 & 102,13 \\
\hline Total & 143 & 335,65 \\
\hline $\mathrm{X}^{2}{ }_{(0,95 ; 23)}=35,17 / \mathrm{X}^{2}{ }_{(0,99 ; 23)}=41,68$ & &
\end{tabular}


4.4-B. Análise de "deviance"para o número de colônias no local 1.

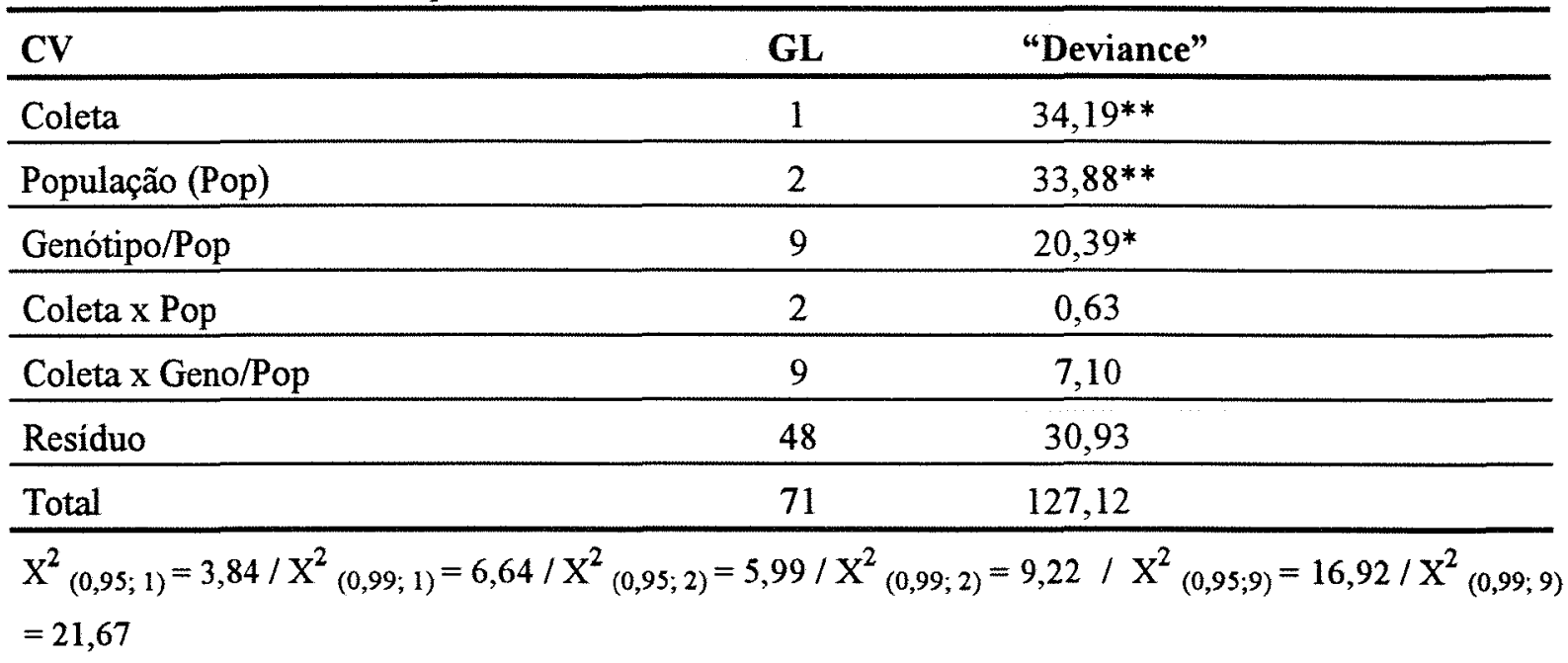

4.4-C. Análise de "deviance" para os contrastes de interesse.

\begin{tabular}{|c|c|c|}
\hline $\mathrm{CV}$ & GL & "Deviance" \\
\hline Parentais $\mathrm{x}$ Híbridos $(\mathrm{H})$ & 1 & $9,43^{* *}$ \\
\hline Pop $1 \times$ Pop 2 & 1 & $24,45^{* *}$ \\
\hline (População) & (2) & $(33,88)$ \\
\hline Entre Geno/Pop 1 & 2 & 2,78 \\
\hline Entre Geno/Pop 2 & 2 & 4,43 \\
\hline Entre Geno/Pop $1 \times 2(\mathrm{H})$ & 5 & $13,18 * *$ \\
\hline (Geno/Pop) & (9) & $(20,39)$ \\
\hline
\end{tabular}

4.4-D. Análise de "deviance" para o número de colônias no local 2.

\begin{tabular}{lcc}
\hline CV & GL & "Deviance" \\
\hline População (Pop) & 2 & $10,90^{* *}$ \\
\hline Geno/Pop & 9 & $21,53^{*}$ \\
\hline Coleta & 1 & $9,31^{* *}$ \\
\hline Coleta X Pop & 2 & $18,58^{* *}$ \\
\hline Coleta x Geno/Pop & 9 & 11,02 \\
\hline Residuo & 48 & 41,78 \\
\hline Total & 71 & 113,12 \\
\hline$X^{2}{ }_{(0,95 ; 1)}=3,84 / X_{(0,99 ; 1)}^{2}=6,64 / X_{(0,95 ; 2)}^{2}=5,99 / X_{(0,99 ; 2)}^{2}=9,22$ & $/ X_{(0,95 ; 9)}^{2}=16,92 / X^{2}(0,99 ; 9)$ \\
$=21,67$ & &
\end{tabular}


4.4-E. Análise de "deviance" para o número de colônias, no local 2, com desdobramento da interação coleta $\mathrm{x}$ população e de genótipos dentro da população.

\begin{tabular}{lll}
\hline CV & GL & "Deviance" \\
\hline Entre Geno/Pop 1 & 2 & 1,07 \\
\hline Entre Geno/Pop 2 & 2 & 0,88 \\
\hline Entre Geno/Pop 1X2 & 5 & $19,58^{* *}$ \\
\hline (Geno/Pop) & $(9)$ & $(21,53)$ \\
\hline Entre Coletas/Pop 1 & 1 & $15,07^{* *}$ \\
\hline Entre Coletas/Pop 2 & 1 & 0,06 \\
\hline Entre Coletas/Pop 1X2 & 1 & $12,76^{* *}$ \\
\hline$($ Coleta/Pop) & $(3)$ & $(27,89)$ \\
\hline$X^{2}{ }_{(0,95 ; 1)}=3,84 / X^{2}{ }_{(0,99 ; 1)}=6,64 / X^{2}{ }_{(0,95 ; 2)}=5,99 / X^{2}{ }_{(0,99 ; 2)}=9,22$ & $/ X_{(0,95 ; 5)}=11,08 / X_{(0,99 ; 5)}$ \\
$=15,10$ & &
\end{tabular}

Embora muito pouco seja conhecido para justificar quaisquer conclusões seguras, pode-se especular que tais diferenças entre locais seriam devidas principalmente à influência de fatores ambientais na associação endófitohospedeiro, neste caso possivelmente devido à diferença no tipo de solo dos dois locais. Desta forma, a associação endófito-hospedeiro poderia estar sendo influenciada em sua especificidade, por um ou mais fatores ambientais, os quais influenciariam fatores genéticos no hospedeiro e conseqüentemente na interação deste com o endófito. Futuyma (1992) discute a variação genética entre populações citando que solos impregnados de metais nas proximidades de minas são ocupados por populações de gramíneas tolerantes aos metais, que são distintas, geneticamente das plantas co-específicas de solos não tóxicos situados a poucos metros de distância, e de acordo com este autor, muito freqüentemente, a adaptação de diferentes populações de uma mesma espécie a condições ambientais similares é fenotípicamente indistinguível, mas apresenta uma base genética diferente de uma população para a outra. Desta forma, ao considerarmos uma associação de duas espécies distintas entre si, e dessa com fatores ambientais, teríamos respostas muito mais complexas, sendo necessário o melhor conhecimento de aspectos biológicos e ecológicos específicos de tal associação, para conclusões mais específicas. 


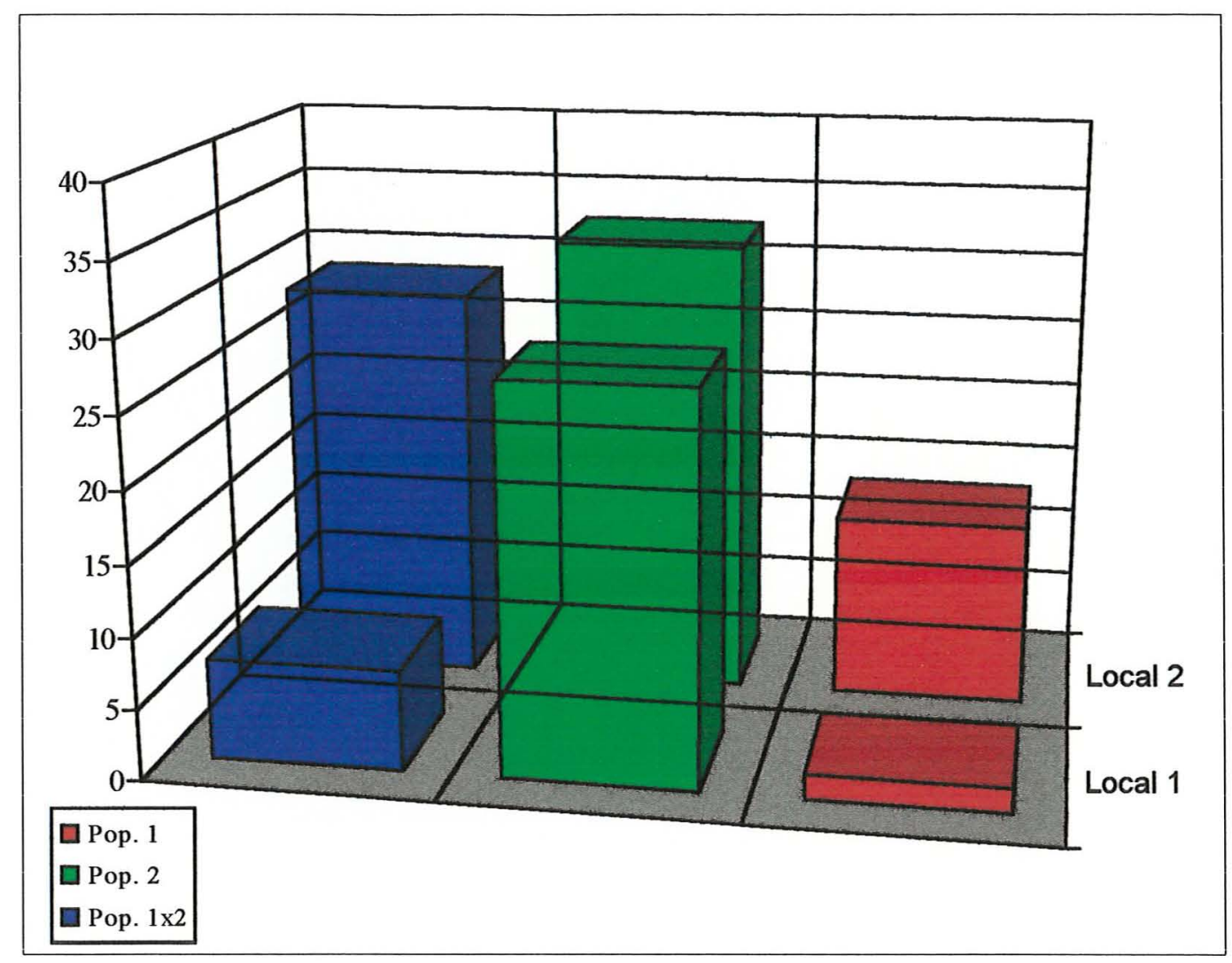

Figura 4.3. Gráfico representativo das percentagens relativas de ocorrência de bactérias endofíticas, em dois locais, em três populações de milho. Considerando-se juntas as duas coletas. Legendas: Local $1=$ Fazenda Areião; Local 2= Caterpillar (Áreas experimentais do Depto Genética ESALQ/USP); P1 (BR-105); P2 (BR106); P1x2 (híbridos simples entre P1 e P2). Ocorrência total de 169 colônias.

Considerando-se a diferença entre locais, os efeitos dos fatores que compõem os tratamentos (Tabelas 4.2 e 4.3), foram estudados em cada local, separadamente, o que foi realizado por meio de análises individuais para cada local considerado.

Observando-se a Figura 4.2., pode-se verificar que quando comparados os valores totais de ocorrência de colônias de endofíticos nas três populações de milho, considerando-se locais e coletas, o Local 2 e a Coleta 1 apresentaram a maior percentagem relativa de colônias. Entretanto, ao desdobrar-se este gráfico, levando em conta as três populações individualmente com relação a local (Figura 4.3), nota-se uma certa estabilidade na ocorrência de colônias de endófitos na população 2 , onde esta diferença somente foi significativa para as populações 1 e 1x2 (Tabela 4.4-D). Pela comparação das Figuras 4.4 e 4.5, verificase que esta estabilidade é devida em sua maior parte ao local 2. 


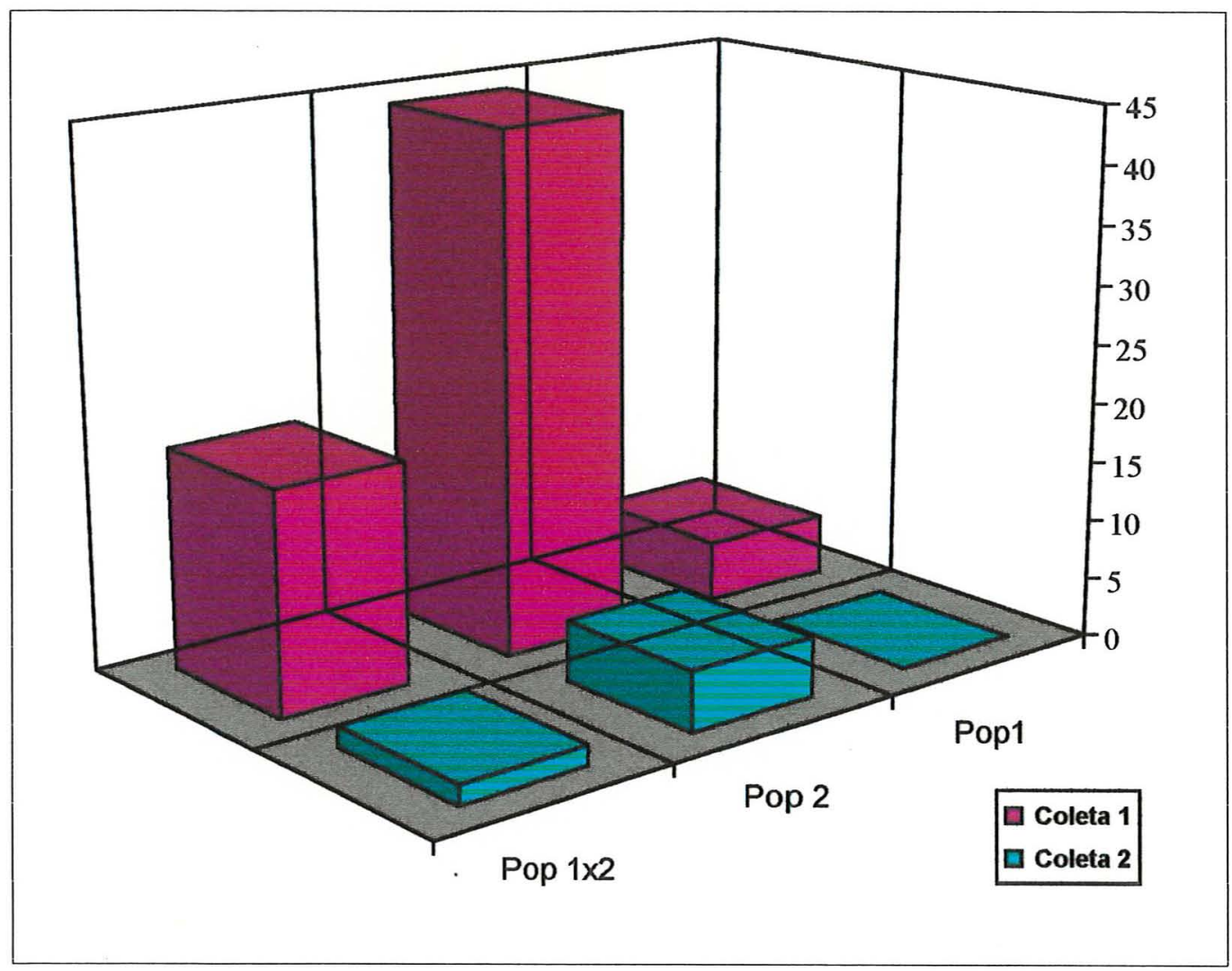

Figura 1. Percentagem relativa de colônias de bactérias endofíticas em milho no Local 1, coletas 1 e 2 , nas populações 1,2 e $1 x 2$.

A Figura 4.6 demonstra as percentagens relativas de colônias nas três populações, nas duas coletas. Pode-se verificar que a coleta 1 apresentou a maior percentagem de ocorrência de colônias nas três populações consideradas com relação à coleta 2 , sendo esta diferença significativa ao nível de $1 \%$ de probabilidade, para ambos locais (Tabelas 4.4-B e 4.4-D).

Posto que a primeira coleta foi realizada com plantas de milho de aproximadamente 6,5 semanas de cultivo, quando estas estavam em sua fase de crescimento vegetativo e início do florescimento, e a segunda coleta, em plantas com 10 semanas, com as plantas de milho já em uma fase de maturidade reprodutiva, tal fato se refletiria na diminuição da população de microrganismos endofíticos, talvez devido à diminuição de nutrientes disponíveis nas partes aéreas das plantas nesta fase de maturidade reprodutiva. Estes resultados concordam, em parte com os encontrados por McInroy \& Kloepper (1991), que isolaram diversos gêneros de haste e raiz de plantas de milho em região temperada, onde verificaram 
decréscimo da população de endófitos na fase de maturidade das plantas, quando comparada com a fase de plântulas, tanto quantitativamente, pela diminuição total da população de endófitos, como qualitativamente, considerando-se o desaparecimento de alguns gêneros. Tais resultados levaram esses autores a sugerirem ocorrerência de competição intergenérica, possivelmente devido ao decréscimo de nutrientes, ou ainda devido ao acréscimo de metabólitos tóxicos acumulados na fase de maturidade das plantas, diminuindo assim a população de endofitícos.

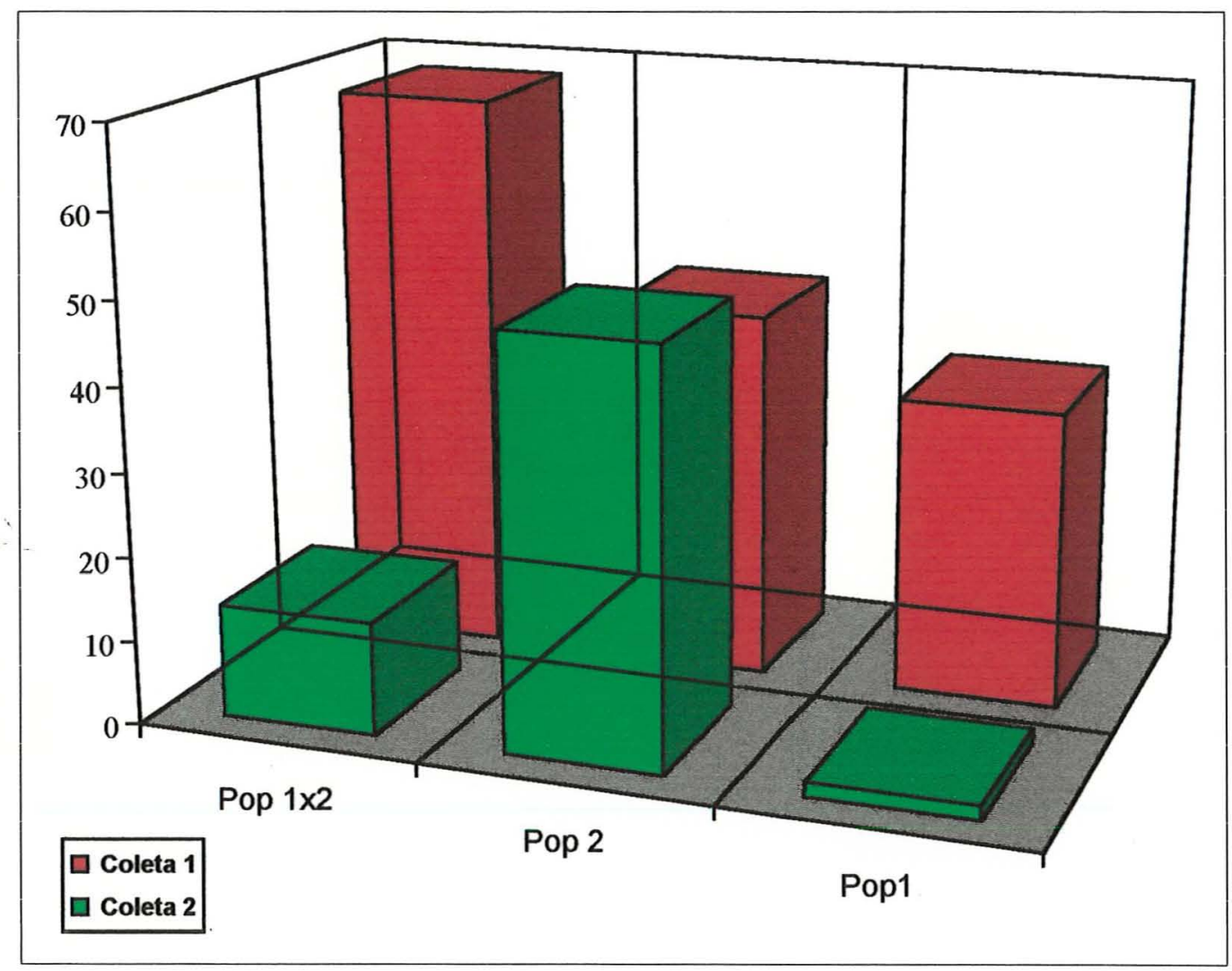

Figura 4.5. Gráfico representativo da percentagem relativa de colônias de bactérias endofíticas em milho no Local 2, coletas 1 e 2, nas populações P1, P2 e P1x2. Legendas: P1= BR-105; P2=BR-106; P1x2= híbridos simples entre P1 e P2.; Coleta 1=6,5 semanas de cultivo; Coleta $2=10$ semanas de cultivo.

Considerando-se as diferenças entre as populações parentais P1 e P2, e entre essas e a P1x2 na ocorrência de endófitos, estas somente foram significativas no Local 1 (Tabela 4.4-C). Entretanto a P1x2 foi a única a apresentar em ambos locais diferenças significativas entre os genótipos (Tabelas 4.4-C e 4.4-E). Estes resultados sugerem uma maior homogeinidade na especificidade dos endófitos pelos 
diferentes genótipos ensaiados nas populações parentais, do que na $\mathrm{P} 1 \times 2$, onde provavelmente os genótipos são muito mais heterogêneos entre si.

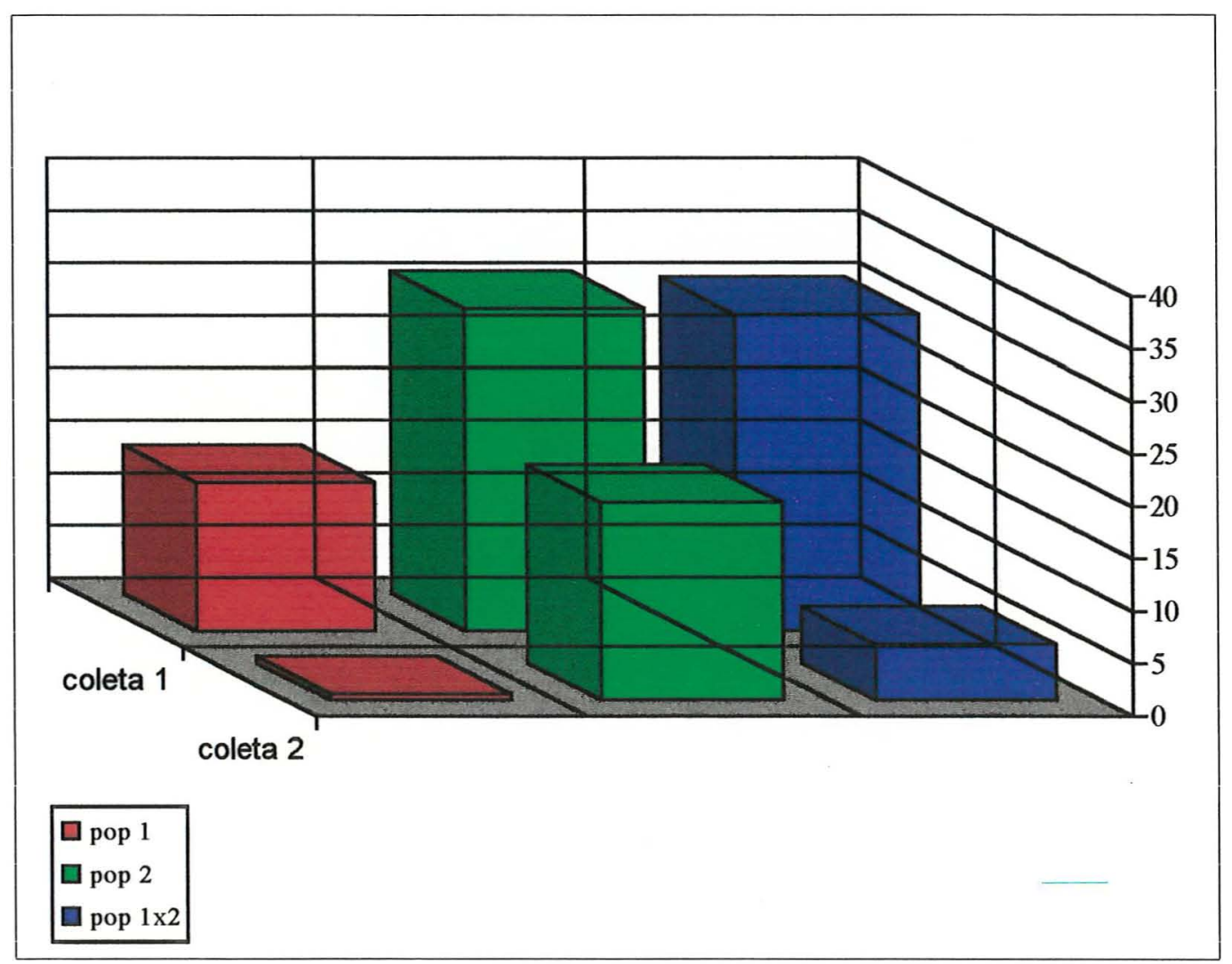

Figura 4.6. Gráfico representativo da percentagem relativa de ocorrência de bactérias endofíticas de milho, nas coletas 1 e 2, nas populações de milho P1, P2 e P1x2. Considerando-se juntos os dois locais. Legendas: Coleta 1= 6,5 semanas de cultivo; Coleta 2= 10 semanas de cultivo; P1 (BR-105); P2 (BR-106); P1x2 (híbridos simples entre P1 e P2). Ocorrência total de 169 colônias.

Devido a escassez de estudos referentes a especificidade de bactérias endofíticas com seus hospedeiros vale ressaltar aqui um importante estudo realizado por Sieber et al. (1988), com fungos endofíticos de trigo. Estes autores abordaram no referido estudo quatro aspectos distintos: 1) comparando as relações do endofítico Septoria nodorum em quatro diferentes variedades de trigo de inverno; 2) registrando a ocorrência desses fungos em trigo; 3) comparando as populações de fungos endofíticos em lugares com diferentes condições climáticas, e por fim, 4) comparando a frequência de isolados em diferentes órgãos de plantas. As espécies de fungos mais frequentes isoladas a partir de raízes, colmo, folhas, glume e semente 
semente foram agrupadas em quatro grupos. Tais autores também demonstraram que as populações de fungos endofíticos são significativamente influenciadas pelas diferentes condições climáticas dos ambientes onde se encontram os hospedeiros. Em ordem de importância, influenciaram as populações de fungos, quantitativa e qualitativamente, em ordem decrescente: órgãos da planta, ambiente, período vegetativo e por último a cultivar.

\subsection{Identificação dos isolados bacterianos}

Dentre os 169 isolados iniciais foram selecionados para identificação 30 que representavam tipos morfológicos distintos. A lista dos isolados identificados o respectivo gênero a que pertencem são indicados na Tabela 4.5. As Tabelas $4.6 \mathrm{e}$ 4.7 trazem as características bioquímicas e morfológicas apresentadas pelos diferentes gêneros identificados neste trabalho. As identificações foram realizadas na Fundação Tropical de Tecnologia "Andre Tosello", Campinas (SP), de acordo com métodos bioquímicos e morfológicos clássicos

O gênero mais frequente foi Bacillus, perfazendo $55 \%$ dos isolados identificados. A Figura 4.7 mostra a distribuição dos gêneros identificados. Lalande et al. (1989) relataram em raiz de 20 plantas de híbridos de milho, a ocorrência de $88 \%$ de endofíticos pertencentes ao gênero Bacillus, $11 \%$ de Pseudomonas e $1 \%$ de Corynebacterium. McInroy \& Kloepper (1991), também em milho, relataram o gênero Bacillus como o mais ocorrente, seguido por Pseudomonas, verificando a ocorrência destes gêneros tanto em fase pós germinativa, quanto na fase de maturidade das plantas.

Os resultados acima relatados, diferem parcialmente dos encontrados por Fisher et al. (1992) em haste de milho, onde os gêneros isolados foram Enterobacter, Pseudomonas, Klebsiela e Vibrio. 
Tabela 4.5. Identificação dos isolados de bactérias endofíticas de milho quanto ao gênero.

\begin{tabular}{l|l}
\hline Gênero & Isolados \\
\hline Bacillus & EN160/EN125/EN94/EN44/EN31/EN45/ \\
& EN166/EN159/EN164/EN43/EN152/EN90/ \\
& EN01/EN06/EN57 \\
Corynebacterium & EN156/EN57/EN69/EN113/EN122 \\
Erwinia & EN96 \\
Listeria & EN104/EN121/EN75 \\
Micrococcus & EN65/EN19/EN112/EN101 \\
Pseudomonas & EN56/EN78 \\
\hline
\end{tabular}

De acordo com Holt et al. (1994), os gêneros identificados têm as seguintes ocorrências: Bacillus, encontrados numa grande variedade de habitates, com poucas espécies sendo patogênicas a vertebrados ou invertebrados; Corynebacterium, fundamentalmente parasitas obrigatórios de membranas mucosas ou pele de mamíferos, ocorrem ocasionalmente em outras fontes, com algumas espécies sendo patogênicas aos mamíferos; Erwinia, gênero associado a plantas como patógenos, saprófitas, ou constituintes da flora epifítica, sendo muito raramente isolados de seres humanos; Pseudomonas, gênero amplamente distribuído na natureza, sendo algumas espécies patogênicas para o homem, animais e plantas; Micrococcus, gênero que ocorre fundamentalmente na pele de mamíferos e no solo, sendo também muito isolado de produtos alimentícios e do ar.

Entretanto, numerosos trabalhos atuais vêm relatando alguns desses gêneros como endófitos de diversas culturas. O gênero Bacillus já foi isolado, como endófito, também em plantas de algodão (Misaghi \& Donndelinger, 1990) e de beterraba (Jacobs et al., 1985).

Cother \& Dowling (1986) isolaram de cebola dentre outros, o gênero Erwinia; em plantas de soja Völksch et al. (1992) isolaram Erwinia e Pseudomonas; em algodão Misaghi \& Donndelinger (1990) isolaram Bacillus e Erwinia. Em plantas de cactus os gêneros Pseudomonas e Erwinia foram isolados por Foster \& Fogleman (1993); em girassol (Helianthus annuus) o gênero Pseudomonas foi encontrado por Fages \& Lux (1991). Ainda em beterraba foram encontrados os 
gêneros Corynebacterium, Erwinia e Pseudomonas (Jacobs et al., 1985), todos na forma endofitica.

Certamente esta lista de gêneros de bactérias endofiticas poderia se estender bastante, visto que atualmente vêm se intensificando os estudos de isolamento destes microrganismos em inúmeras culturas agrícolas, mas o intuito aqui foi simplesmente o de enumerar alguns dos gêneros encontrados na forma endofítica e associar com os resultados obtidos neste trabalho com os dados já citados anteriormente na literatura, o que vem complementar os dados de ocorrência para alguns desses gêneros citados por Holt et al. (1994). 


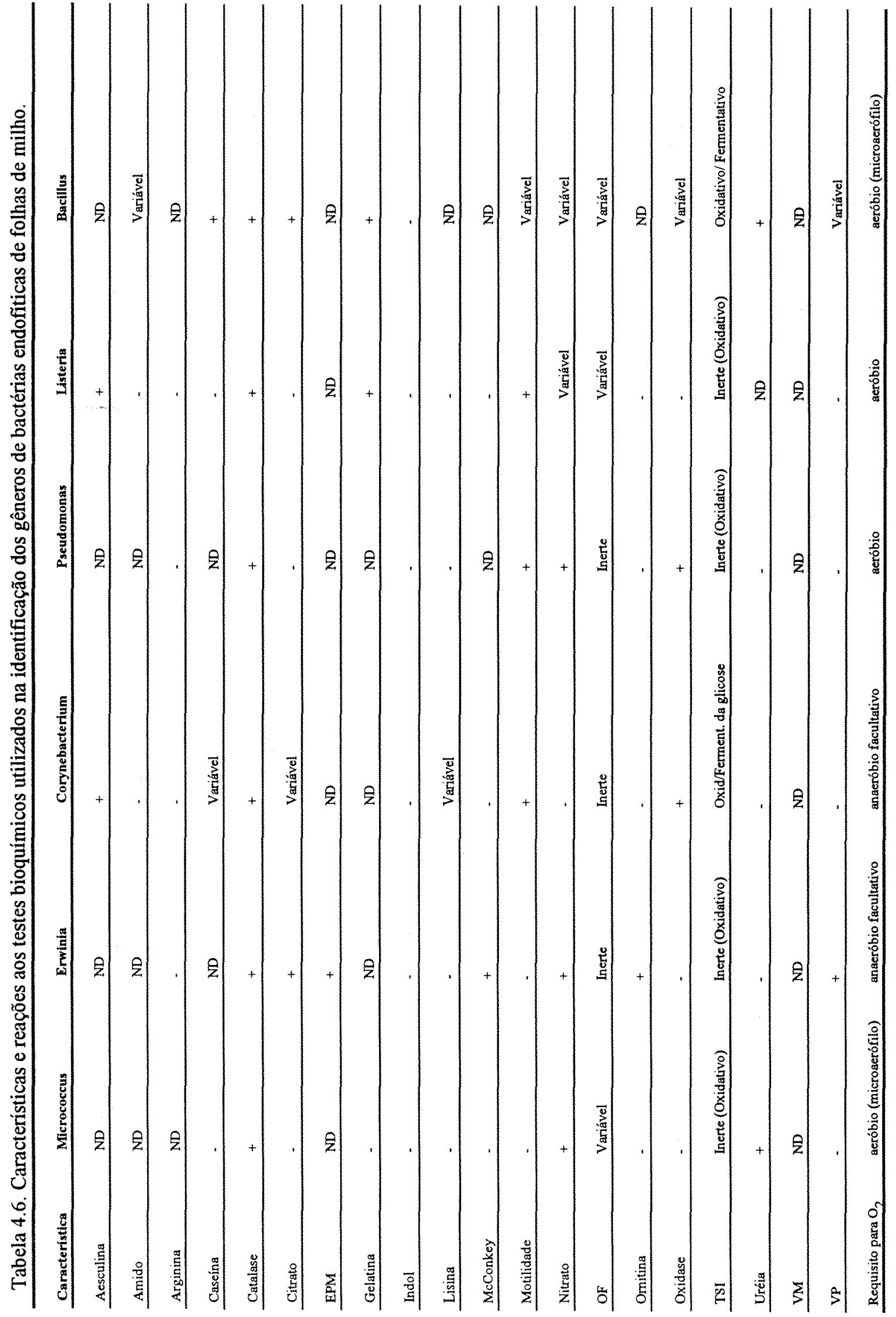




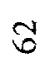

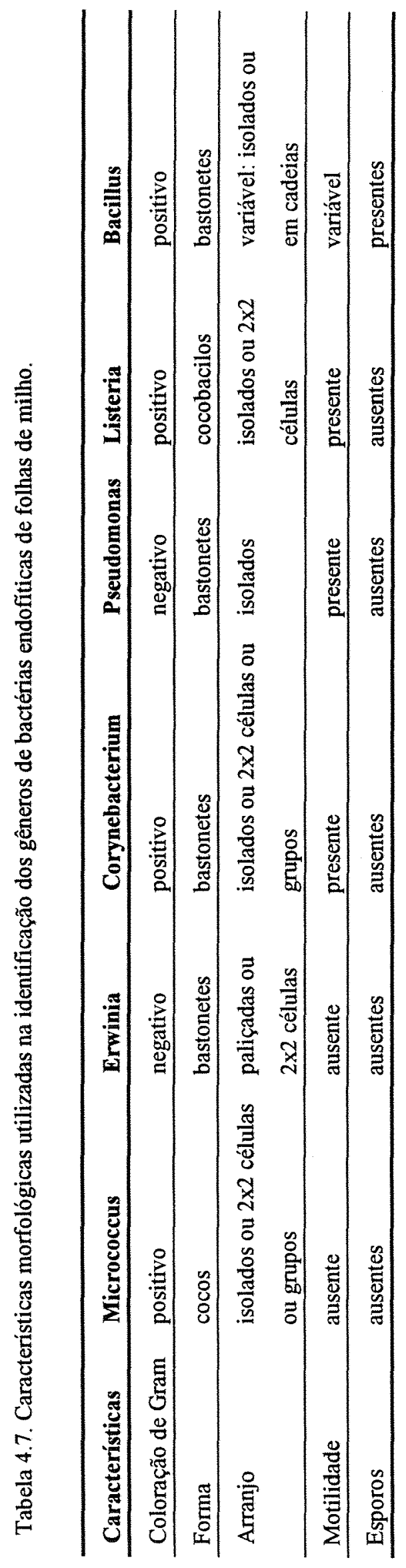




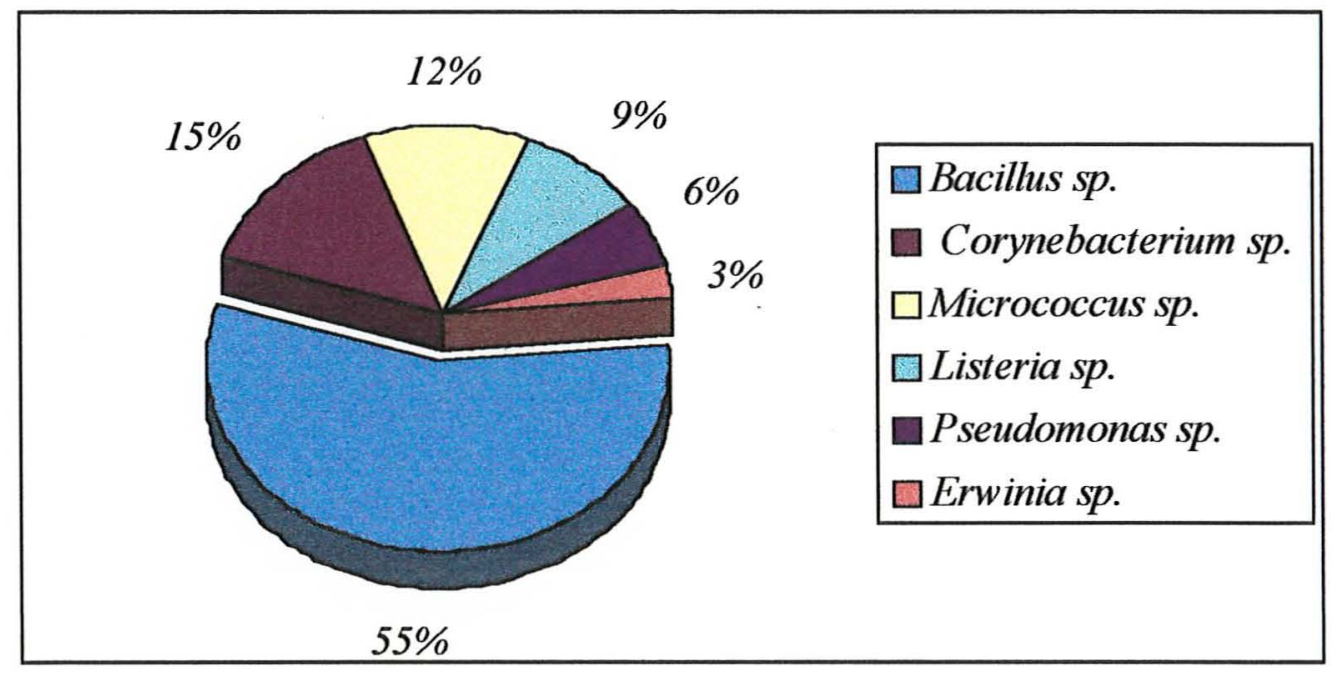

Figura 4.7. Distribuição em percentagem de gêneros de bactérias endofíticas isoladas de folhas de plantas de milho (Zea mays L.).

\subsection{Teste antagonístico in vitro}

Os resultados obtidos com este ensaio mostram que não houve produção de compostos tóxicos pelos fungos endofíticos isolados de milho, capazes de afetar ou inibir o crescimento das bactérias endofíticas selecionadas ao acaso e ensaiadas in vitro (Tabela 4.8), indicando um tipo de associação diferente da que ocorreu entre os isolados EN01 e EN07, pertencentes ao gênero Bacillus e duas linhagens sabidamente produtoras de penicilina de Penicillium crhysogenum utilizadas como controle. Nesse caso, ocorreu uma antibiose.

Diversos aspectos poderiam ser discutidos aqui, quanto a não incidência de reação antagonística entre os fungos e as bactérias endofíticas ensaiadas, neste caso isolados de plantas pertencentes às mesmas populações. Mas um aspecto interessante é que tais resultados trazem indícios de uma associação benéfica entre os diferentes microrganismos endofíticos. Entretanto, Assis et al.(1995) utilizaram com sucesso Bacillus spp e bactérias endofíticas obtidas do filoplano de couve, repolho, rabanete e couve-flor, como agentes antagonistas a Xanthomonas campestris, sob condições de casa de vegetação, indicando a utilização desses microrganismos no controle biológico de doenças causadas por este fitopatógeno. 
Em estudos posteriores seria de grande valia no entendimento da associação planta-microrganismos endofíticos, estudos de reinfecção desses microrganismos em plantas axênicas de milho, em condições de casa de vegetação. Desta forma alguns dos mecanismos envolvidos na associação poderiam ser investigados de maneira mais abrangente. Entretanto, os resultados aqui obtidos endossam a possível ocorrência destes microganismos como endófitos simultâneos de plantas de milho. Dentro deste contexto, seriam de grande valia também investigações abordando o referido tema, com relação a especificidade $\mathrm{e}$ estabelecimento desse fenômeno; funções regulatórias dos microrganismos endofíticos na planta; e sobre o controle das interações microrganismos-planta durante a fase endofítica (não-patogênica).

Tabela 4.8. Crescimento in vitro de isolados de bactérias endofiticas de milho, em associação com linhagens de fungos endofíticos Penicillium spinulosum (PsL2), P. purpurogenum (PpL19) e Fusarium moniliforme (FmL38), e não endofíticos e produtores de penicilina P. chrysogenum (Pc4626 e Pc1671).

\begin{tabular}{llllll}
\hline Isolado & Pc4626 & Pc1671 & PsL2 & PpL19 & FmL38 \\
\hline E01 Bacillus & - & - & + & + & + \\
\hline E05 N.I. & + & + & + & + & + \\
\hline E06 Bacillus & + & + & + & + & + \\
\hline E16 N.I. & + & + & + & + & + \\
\hline E19 Micrococcus & - & - & + & + & + \\
\hline E57 Bacillus & + & + & + & + & + \\
\hline E65 N.I. & + & + & + & + & + \\
\hline E69 Corynebacterium & + & + & + & + & + \\
\hline E101 Micrococcus & + & + & + & + & + \\
\hline E112 Micrococcus & + & + & + & + & + \\
\hline
\end{tabular}

$(+)=$ Crescimento bacteriano

$(-)=$ Ausência de crescimento bacteriano

N.I.* = Isolado não identificado 


\subsection{Análise de RAPD}

\subsubsection{Padronização da técnica e seleção de oligonucleotídios}

Inicialmente o DNA genômico de dois isolados, denominados EN103 e EN06, foram utilizados para ajuste da reação de amplificação, onde variaram as concentrações de DNA genômico, magnésio e Taq-DNA polimerase. De acordo com Williams (1993) as principais variáveis a serem ensaiadas são as concentrações de DNA genômico e de $\mathrm{Mg}$, pois uma concentração alta desses componentes pode causar perda de bandas e quando muito baixa, pode originar bandas não reproduzíveis. A escolha do "primer" pode influenciar a quantidade de informação genética obtida sobre as relações entre os isolados ensaiados e a utilização de outros "primers" com os mesmos isolados pode clarear as similaridades ou diferenças que de outra forma poderiam permanecer não detectáveis (Harrison et al., 1992). Portanto, este pré-teste serviu também para seleção de primers, cujos padrões de amplificação se encontram na Figura 4.8.

Segundo Williams et al. (1990) "primers" com menos de 9 nucleotidios são ineficientes para produzir amplificação em soja. Entretanto o tamanho do genoma de bactérias é muito menor e, com o uso de "primers" mais longos pode-se esperar menos informação, devido ao tamanho limitado dos genomas desses procariotos, que possuem poucos sítios alvo (Harrison et al., 1992). Em vista disso foram utilizados no presente trabalho "primers" de 10 nucleotídios, onde verificou-se a habilidade de amplificar DNA de Bacillus spp. Um outro fato relevante foi descrito por Williams et al. (1990), onde demonstraram que "primers" usados para amplificar DNA de soja deveriam ter pelo menos $40 \%$ de conteúdo de bases CG e que um bom padrão de amplificação foi obtido com até $100 \%$ de CG. Também a temperatura de anelamento deve ser maior para "primers" com alto conteúdo CG e os dados de Caetano-Anollés et al. (1991) indicaram que primers com alto conteúdo CG dão mais produtos de amplificação. No presente trabalho os "primers" utilizados tinham todos $70 \%$ de $\mathrm{CG}$, e suas estruturas e composição de bases estão na tabela 3.6.1(Material e Métodos).

Foram ensaiadas concentrações de DNA genômico de 2,5; 5,0;10,0 e 25,0ng/reação, concentrações de $\mathrm{MgCl}_{2}$ variando de 2 a $5 \mathrm{mM}$ e concentrações de Taq-DNA polimerase de 0,5 a 2,0U. Vinte oligonucleotídios pertencentes aos "kits" OPX e OPE (ítem 3.3.18), foram ensaiados. Em todos os experimentos foram 
realizadas reações controle, sem conteúdo de DNA genômico, para verificar a possível ocorrência de amplificação por contaminantes.

Foram selecionadas as concentrações de Taq-DNA polimerase $(2,0 \mathrm{U})$; $\mathrm{MgCl}_{2}(6,5 \mathrm{mM})$ e quantidade de DNA genômico (5ng), e dos vinte diferentes oligonucleotídios ensaiados com DNA genômico dos isolados endofiticos (EN103 e EN06), foram selecionados para as reações de amplificação os cinco a seguir: OPX07, OPE02, OPE11, OPE12 e OPE14 (Tabela 3.6.1). Dentre os vinte oligonucleotídios ensaiados, não apresentaram padrões de amplificação em ambos isolados utilizados, os oligonucleotídios OPE01, OPE04, OPE13, OPX01 e OPX04. As condições de amplificação foram padronizadas para todos os oligonucleotídios ensaiados (ítem 3.6.2).

\subsubsection{Polimorfismo por RAPD}

Após a otimização da técnica de RAPD, foram ensaiados os DNAs extraídos de treze isolados endofíticos pertencentes ao gênero Bacillus, referentes a três populações hospedeiras distintas, obtidos em dois diferentes locais (Caterpillar e Faz. Areião- Áreas Experimentais do Depto. Genética da ESALQ/USP), em duas coletas em cada local respectivo. Juntamente com esses, foram também ensaiadas duas linhagens de referência, não endofiticas: Bacillus megaterium 3026 e Bacillus subtilis 2471, para verificar as relações entre esses e os isolados endofíticos (Tabela 4.9).

Estudos recentes têm sido realizados em muitas espécies de bactérias, visando verificar as relações entre dois grupos patogenicamente distintos, para o estabelecimento de um sistema de subespécies ou patovares, como o realizado por Chen et al. (1995), em Xylella fastidiosa. Outros autores como Harrison et al. (1992), têm procurado por meio da técnica de RAPD, um método de identificação de estirpes de Rhizobium leguminosarum biovar trifolii, que pudesse distinguí-las rapidamente entre um número limitado de estirpes em sistemas artificiais e também pudesse ser utilizado no estudo de populações selvagens. Uma técnica como o RAPD pode ser otimizada, de acordo com as características de cada espécie e aperfeiçoada para a utilização em diversos ensaios, evitando técnicas empregadas com êxito atualmente, mas que consomem muito tempo e são relativamente dispendiosas, como o RFLP. 
Tabela 4.9. Dados referentes ao código dos isolados utilizados no ensaio de RAPD, e seus respectivos locais de coleta, número de coleta e população de milho hospedeira $(\mathrm{P} 1=\mathrm{BR} 105$; $\mathrm{P} 2=\mathrm{BR} 106$ e $\mathrm{P} 1 \times 2=$ Híbridos simples entre P1 e P2). Coleta 1=6,5 semanas de cultivo; Coleta 2=10 semanas de cultivo.

\begin{tabular}{lllll}
\hline Código RAPD & Isolado & Local de Coleta & Coleta & Populacão Hospedeira \\
\hline E01* & 2471 & - & & \\
\hline E02* & 3026 & - & & \\
\hline E03 & EN43 & Caterpillar & 1 & P2 \\
\hline E04 & EN45 & Caterpillar & 1 & P2 \\
\hline E05 & EN06 & Areião & 1 & P2 \\
\hline E06 & EN82 & Caterpillar & 1 & P1 \\
\hline E07 & EN91 & Caterpillar & 1 & P1x2 \\
\hline E08 & EN164 & Caterpillar & 2 & P2 \\
\hline E09 & EN160 & Caterpillar & 2 & P2 \\
\hline E10 & EN159 & Caterpillar & 2 & P2 \\
\hline E11 & EN125 & Caterpillar & 1 & P1x2 \\
\hline E12 & EN152 & Caterpillar & 2 & P2 \\
\hline E13 & EN31 & Areião & 1 & P1x2 \\
\hline E14 & EN103 & Caterpillar & 1 & P1x2 \\
\hline E15 & EN166 & Caterpillar & 2 & P2 \\
\hline$*$
\end{tabular}

* Linhagens de referência

No presente estudo, obtiveram-se padrões de bandas distinguíveis entre os isolados endofíticos de Bacillus, quando utilizados os seus DNA's e cinco dos oligonucleotídios ensaiados e selecionados previamente: OPX07, OPE02, OPE14, OPE12 e OPE11, tendo sido obtidas 67 bandas, onde todas se mostraram polimórficas. Os oligonucleotídios produziram de 7 a 18 bandas, sendo 13 o número médio de bandas obtidas nos cinco oligonucleotídios usados. Um padrão representativo das bandas é mostrado na figura 4.9. Houveram dois tipos de bandas de DNA, que podem ser definidas como fortes ou fracas, o que já havia sido encontrado previamente por Chen et al. (1995), na bactéria Xylella fastidiosa. 


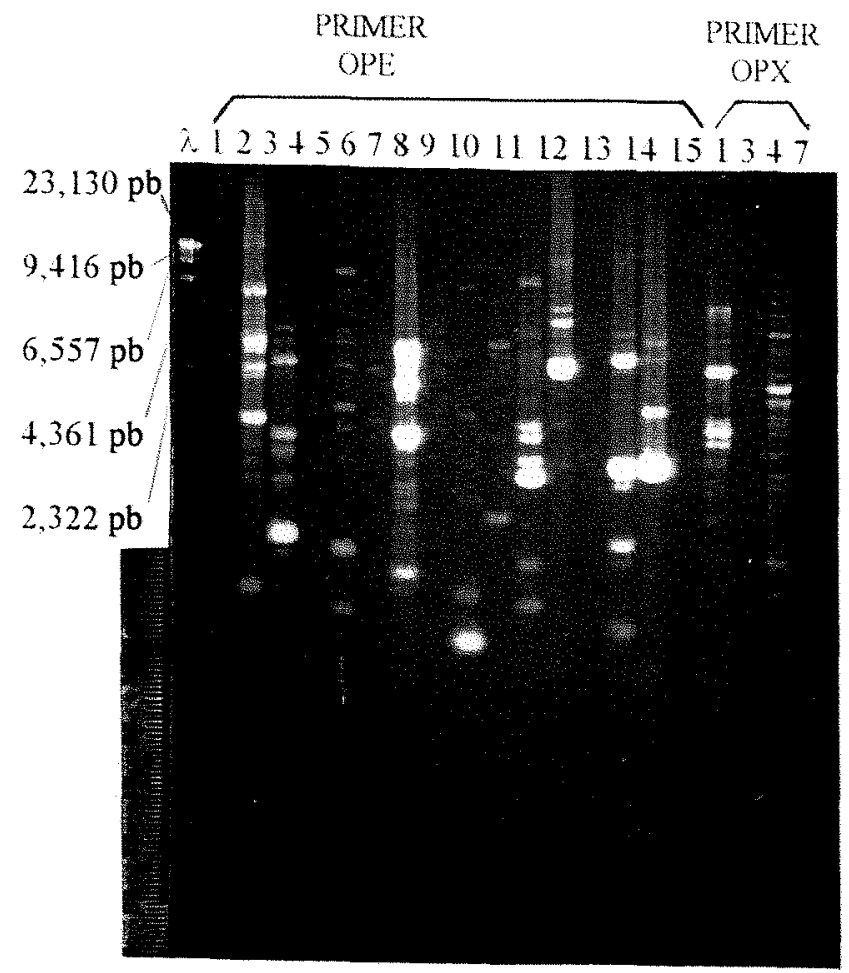

ISOLADO ENI03

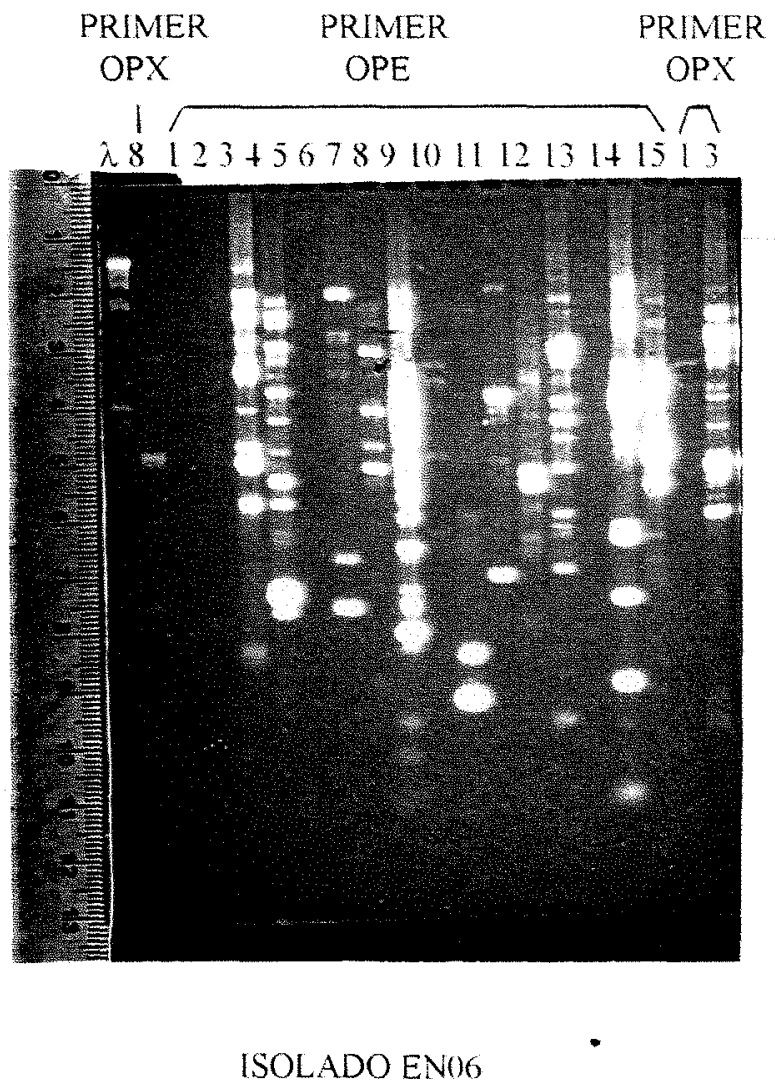

Figura 4.8. Padrão de seleção de "primers" em linhagens endofíticas de Bacillus sp. isolados de folhas de milho. (A) "Primers" OPE (01 a 15) e OPX (01, 04, 07, 03), testados no isolado EN103; (B) "primers" OPX-08, isolado EN103; "primers" OPE (01 a 15) e OPX (01 e 03), testados no isolado EN06. 

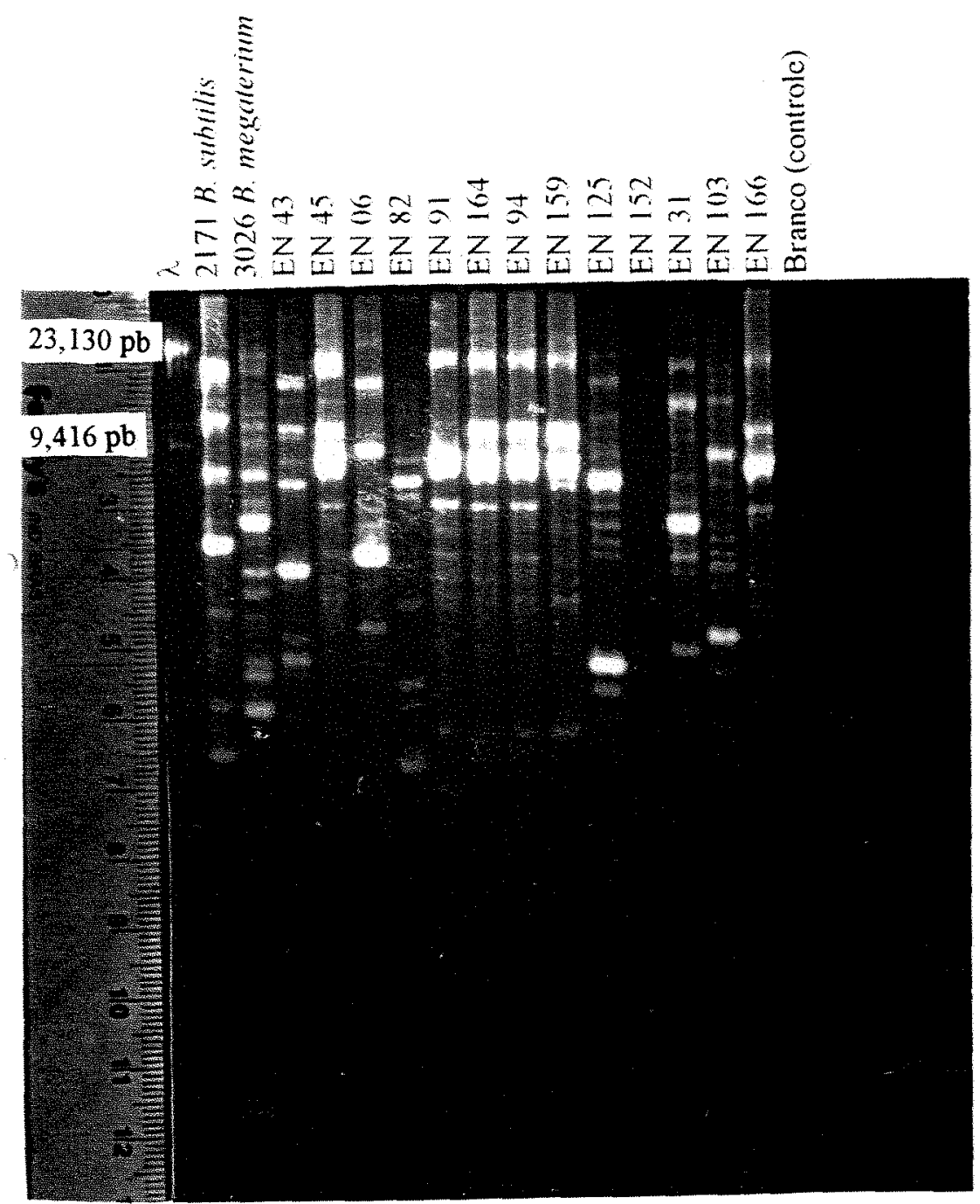

Figura 4.9. Padrão representativo de bandas obtidas por amplificação com o primer E14, em linhagens endofiticas de Bacillus sp. isolados de folhas de milho. Da esquerda para a direita da foto observa-se na primeira canaleta o padrão $\lambda$, nas duas canaletas subsequentes os padrões de bandas dos Bacillus não endofíticos e os restantes são os padrões de bandas dos isolados endofiticos. 
Os padrões de amplificação foram utilizados para a construção da matriz de similaridade (Figura 4.10), e para estabelecimento de uma possível associação dos coeficientes de similaridade resultantes da análise UPGMA, com o local de coleta, coleta e população hospedeira de origem entre os isolados endofíticos analisados.

O perfil de bandas obtidas com o primer OPE14 mostrado na figura 4.9 mostra que para um primer individual os isolados apresentaram até 14 diferentes bandas nítidas. Foram ainda obtidas 12 bandas nítidas com o primer OPX07, sete com o primer OPE02, 18 com o primer OPE12 e 16 com o primer OPE11. Os diferentes perfis de DNA obtidos pelos cinco oligonucleotídios foram combinados e subdivididos dentro dos grupos.

\begin{tabular}{|c|c|c|c|c|c|c|c|c|c|c|c|c|c|c|c|}
\hline & EOI & 802 & ЕО3 & EO4 & EO5 & EOS & EO7 & EOB & $E 09$ & E10 & E11 & E12 & E13 & E14 & E15 \\
\hline 1 & 1.000 & & & & & & & & & & & & & & \\
\hline 2 & 0.375 & 1.000 & & & & & & & & & & & & & \\
\hline 03 & 0.150 & 0.268 & 1.000 & & & & & & & & & & & & \\
\hline 04 & 0.270 & 0.262 & 0.196 & 1.000 & & & & & & & & & & & \\
\hline 05 & 0.125 & 0.186 & 0.359 & 0.227 & 1.000 & & & & & & & & & & \\
\hline E06 & 0.129 & 0.206 & 0.132 & 0.158 & 0.105 & 1.000 & & & & & & & & & \\
\hline 57 & 0.268 & 0.318 & 0.250 & 0.525 & 0.229 & 0.225 & 1.000 & & & & & & & & \\
\hline EOB & 0.209 & 0.261 & 0.224 & 0.694 & 0.180 & 0.225 & 0.692 & 1.000 & & & & & & & \\
\hline 20 & 0.256 & 0.250 & 0.292 & 0.537 & 0.271 & 0.186 & 0.700 & 0.744 & 1.000 & & & & & & \\
\hline 10 & 0.357 & 0.257 & 0.243 & 0.343 & 0.216 & 0.129 & 0.300 & 0.388 & 0.421 & 1.000 & & & & & \\
\hline & 0.265 & 0.324 & 0.244 & 0.268 & 0.250 & 0.212 & 0.357 & 0.326 & 0.341 & 0.162 & 1.000 & & & & \\
\hline 1 & 0.171 & 0.175 & 0.225 & 0.351 & 0.171 & 0.226 & 0.528 & 0.410 & 0.462 & 0.171 & 0.150 & 1.000 & & & \\
\hline 1. & $: 0.300$ & 0.406 & 0.205 & 0.200 & 0.243 & 0.200 & 0.262 & 0.205 & 0.250 & 0.258 & 0.257 & 0.077 & 1.000 & & \\
\hline & 0.188 & 0.158 & 0.243 & 0.205 & 0.286 & 0.094 & 0.130 & 0.130 & 0.174 & 0.188 & 0.194 & 0.171 & 0.182 & 1.000 & \\
\hline & 0.282 & 0.273 & 0.261 & 0.686 & 0.213 & 0.205 & 0.600 & 0.730 & 0.692 & 0.389 & 0.310 & 0.395 & 0.244 & 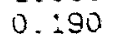 & 0 \\
\hline
\end{tabular}

Figura 4.10. Matriz de similaridade obtida a partir do coeficiente de Jaccard, para os isolados endofiticos de Bacillus sp. isolados de folhas de milho. 


\section{RAPD DE BACILLUS ENDOFITICOS DE MILHO}

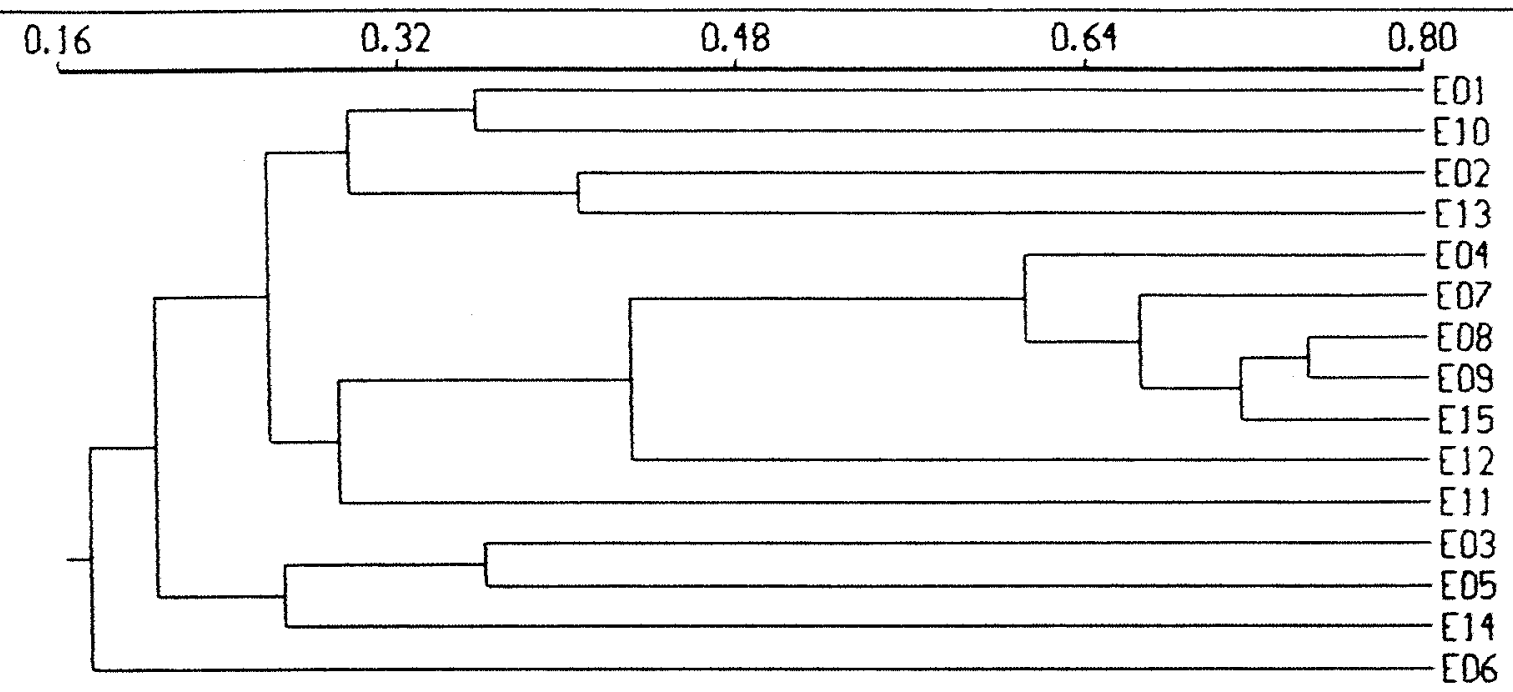

Figura 4.11. Dendrograma usando "UPGMA algoritmo" para agrupar os treze isolados de Bacillus endofíticos e as duas espécies de referência Bacillus megaterium (3026) e Bacillus subtilis (2471), com base em seus índices de similaridade.

Os produtos de amplificação dos isolados foram diferentes, em sua maioria, daqueles obtidos para as espécies de referência: Bacillus megaterium 3026 e Bacillus subtilis 2471, de origem não endófita e obtidos da coleção de culturas da FTPTAT. Exceto para dois dos isolados endofíticos, dentre os 13 isolados endofiticos de Bacillus e as linhagens 3026 e 2471.

Quatro grupos distintos com baixa similaridade, de aproximadamente $32 \%$ puderam ser distinguidos, o que pode ser visto no dendrograma representado na Figura 4.11. Apenas com o intuito de uma comparação, a grosso modo, o coeficiente médio, obtido pelo valor médio da soma dos dados da matriz de similaridade possui valor igual a 0,283 ou $28,3 \%$. Com base em tais resultados, conclui-se que embora os isolados endofíticos sejam do gênero Bacillus, apresentanto portanto características fenotípicas semelhantes aos Bacillus spp. não endofiticos (Linhagens 3026 e 2471), estes não se apresentam geneticamente muito similares.

Nos três primeiros grupos, ocorre a divisão em dois subgrupos. Dentro do primeiro grupo, estão no primeiro subgrupo a linhagem tipo de Bacillus subtilis 2471 e o isolado endofitico de Bacillus EN159, com $40 \%$ de similaridade; no subgrupo 2, estão a linhagem tipo de Bacillus megaterium 3026 e o isolado endofitico EN31, com $45 \%$ de similaridade. 
Os grupos restantes, foram constituídos somente por representantes dos isolados endofiticos. Para o grupo dois, ambos subgrupos um e dois, continham indivíduos provenientes do mesmo local de origem, que era a área experimental da Caterpillar, e provenientes das duas coletas realizadas durante o experimento (1a. e 2a.), e de duas populações distintas (P2 e P1x2). No subgrupo um encontram-se indivíduos com até $70 \%$ de similaridade entre si, como por exemplo os isolados EN164, EN160 e EN166, o que sugere uma relação genética entre eles. Entretanto, o subgrupo 2 é constituído apenas pelo isolado EN125.

No grupo três, encontram-se como representantes dos dois subgrupos indivíduos provenientes também das populações $\mathrm{P} 2$ e $\mathrm{P} 1 \times 2$, porém todos pertenciam à primeira coleta, não havendo especificidade de locais pois provinham tanto da Caterpillar quanto da Fazenda Areião. Por último, único no quarto grupo está o isolado EN82, que curiosamente era o único isolado pertencente à população $\mathrm{P} 1$, esta proveniente de uma planta da primeira coleta na Caterpillar, sendo o índice de dissimilaridade (1-cs) deste com todo o grupo de aproximadamente $84 \%$. Entretanto, morfológicamente e de acordo com os testes bioquímicos, o isolado EN82 pertence ao gênero Bacillus, o que poderia sugerir uma grande diferença entre os isolados de Bacillus das duas populações. Faz-se portanto, necessário uma melhor investigação, aumentando-se o número de isolados pertencentes à população $\mathrm{P} 1$, para uma conclusão acerca do grau de similaridade dos endofíticos provenientes desta com os provenientes de outras populações.

A variação da similaridade em percentagem dentro dos diferentes grupos indicou uma associação entre alguns isolados com a coleta e o local de coleta, como vistos nos grupos dois e três, respectivamente. Tais resultados podem ser considerados como únicos, visto que até a presente não se encontra disponível nenhum estudo referente a análise de RAPD de isolados endofíticos. Portanto, a discussão dos resultados do presente estudo tem sido realizada em grande parte por comparação com análises de isolados ambientais, derivados de alimentos estragados ou patógenos de culturas de grande importância econômica. Isto vem dificultar a adequada abordagem do assunto em questão, pela falta de dados comparativos referentes a outros endofíticos, e especialmente pertencentes aos taxa das bactérias

Até o momento numerosas técnicas para diferenciação de Bacillus spp. foram descritas na literatura, como a sorotipagem, a tipagem utilizando-se fago ("phagetyping"), eletroforese de proteínas, sistemas de tipagem por bacteriocinas e métodos moleculares. De acordo com os resultados do presente estudo, a técnica de RAPD provê uma nova forma de abordagem do assunto em questão, além de já ter 
sido utilizada para a tipagem epidemiológica de Listeria spp. Campylobacter spp. Brucella spp. e Candida spp., segundo Stephan et al. (1994), os quais por sua vez, realizaram a caracterização de Bacillus licheniformis, isolados de alimentos contaminados, por meio da utilização de dois "primers". Os referidos autores determinaram 10 estirpes dentro do grupo de 46 isolados, e encontraram ainda diferentes padrões para oito estirpes de Bacillus spp. de um grupo diferente ao dos isolados. 


\section{CONCLUSÕES}

1.) Bactérias endofíticas são encontradas em milho, tendo sido identificados no presente trabalho seis gêneros: Bacillus sp.; Corynebacterium sp.; Erwinia sp.; Micrococcus sp.; Listeria sp. e Pseudomonas sp, dentre os 30 isolados selecionados ao acaso, como amostra dos diferentes grupos morfológicos definidos entre 169 colônias isoladas.

2.) O gênero mais freqüente entre os isolados representativos da flora bacteriana isoladas de folhas de plantas de milho sadias foi o gênero Bacillus, com $55 \%$ de ocorrência.

3) O estudo de frequência de infecção, através da percentagem de ocorrência de colônias em diferentes genótipos, nas três populações citadas, revelou haver diferenças significativas entre locais, coletas e genótipos nas diferentes populações analisadas. A diferença entre locais sendo provavelmente devida a diferença de solos das duas áreas experimentais testadas; entre coletas refletindo a fase de desenvolvimento da planta e de genótipos, sugerindo uma especificidade entre determinados genótipos hospedeiros e os endófitos analisados.

4.) Existe ampla variabilidade genética entre os treze isolados de Bacillus endofíticos analisados por meio de marcadores RAPD, diferindo os produtos de amplificação, em sua maioria, daqueles obtidos para as espécies de referência: Bacillus megaterium e Bacillus subtilis, de origem não endofitica. A partir da análise da matriz de similaridade e dendrograma obtidos para os isolados testados, não obsevou-se nos quatro grupos com $32 \%$ de similaridade entre si, uma relação geral entre coleta e local de coleta, e os isolados. 
5.) $\mathrm{O}$ ensaio de antagonismo in vitro, entre as bactérias e fungos endofíticos ensaiados no presente estudo, ambos isolados de plantas de milho de mesma origem, revelou não haver produção de compostos tóxicos pelos fungos endofíticos, capazes de afetar ou inibir o crescimento das bactérias endofiticas. 


\section{REFERÊNCIAS BIBLIOGRÁFICAS}

ALEXANDER, D.B.; ZUBERER, D.A. ${ }^{15} \mathrm{~N}_{2}$ fixation by bacteria associated with maize roots at low partial $\mathrm{O}_{2}$ pressure. Applied and Environmental Microbiology, v.55, p. 1748-53, 1989.

ASSIS, S.M.P.; MARIANO, R.L.R.; MICHEREFF, S.J. Antagonismo de Bacillus sp. e bactérias endofiticas a Xanthomonas campestris pv. campestris no filoplano de couve. Fitopatologia Brasileira, Suplemento, v.20, p.287, 1995.

BECKING, J.H. Identification of the endophyte of Dryas and Rubus (Rosaceae). Plant and Soil, v.78, p. 105-28, 1984.

BOWDITCH, B.M.; ALBRIGHT, D.G.; WILLIAMS, J.G.K.; BRAUN, M.J. Use of random amplified polymorphic DNA markers in comparative genome studies. Methods in Enzymology, v.224, p. 294-309, 1991.

BREEN, J.P. Temperature and seasonal effects on expression of Acremonium endophyte-enhanced resistance to Schizaphis graminum (Homoptera: Aphididae). Environmental Entomology, v.21, p. 68-74, 1992.

BUENO, R.; FUNGARO, M.H.P.; AZEVEDO, J.L.; PIZZIRANI-KLEINER, A.A. Fusão de protoplastos e análise de segregantes por RAPD em Penicillium chrysogenum. In: REUNIÃO ANUAL DE GENÉTICA DE MICRORGANISMO, 20, Piracicaba, 1995. Resumos. Piracicaba: BANDEL, G.; PIZZIRANI-KLEINER, A.A.; AZEVEDO, J.L. eds./SBG/USP/ESALQ, 1995, p. 152 . 
CAETANO-ANOLlÉS, G.; BASSAM, B.J.; GRESSHOFF, P.M. Primertemplate interactions during DNA amplification fingerprinting with the single arbitrary oligonucleotides. Molecular General Genetics, v.235, p. 157-165.

CARROLL, G.C. The biology of endophytism in plants with particular reference to woody perennials. In: FOKKEMA, N.J.; HEUVEL, J. Van den, ed. Microbiology of phyllosphere. London: Cambridge University Press, 1986. p. 205-22.

CARROLL, G.C. Fungal endophytes in stems and leaves: from latent pathogen to mutualistic symbiont. Ecology, v.69, p. 2-9, 1988.

CHEN, X. ; LINE, R.F.; LEUNG, H. Relationship between virulence variation and DNA polymorphism in Puccinia striiformis. Phytopathology, v.83, n.12, 1993.

COLOMBO, P.M. Occurrence of endophytic bacteria in siphonous algae. Phycologia, v.17, p. 148-151, 1978.

COTHER, E.J.; DOWLING, V. Bacteria associated with internal breakdown of onion bulbs and their role in disease expression. Plant Pathology, v.35, p. 329-36, 1986.

DAVIS, M.J.; AUGUSTIN, B.J. Occurrence in Florida of the bacterium that causes bermuda grass stunting disease. Plant Disease, v.68, p. 1095-97, 1984.

DAVIS, M.J.; GILLASPIE JUNIOR, A.G.; VIDIVAR, A.K.; HARRIS, R.W. Clavibacter: a new genus containing some phytopathogenic coryneform bacteria, including Clavibacter xyli subsp. xyli sp. nov., subsp. nov. and Clavibacter xyli subsp. cynodontis subsp. nov., pathogens that cause ratoon stunting disease of sugarcane and bermudagrass stunting disease. International Journal Systematic Bacteriology, v.34, p. 107-17, 1984.

DE FREITAS, J.R.; GERMIDA, J.J. Pseudomonas cepacia and Pseudomonas putida as winter wheat inoculants for biocontrol of Rhizoctonia solani. Canadian Journal of Microbiology, v.37, p. 780-84, 1991. 
DÖBEREINER, J. History and new perspectives of diazotrophs in association with non-leguminous plants. Symbiosis, v.13, p. 1-13, 1992.

DÖBEREINER, J. Recent changes in concepts of plant bacteria interactions: endophytic N2 fixing bacteria. Ciência \& Cultura, v.44, p. 310-3, 1992.

DÖBEREINER, J.; URQUIAGA, S. Soil biology and susteinable agriculture. Anais da Academia Brasileira de Ciências, v.64, Supl.1, p. 127-33, 1992.

FAGES, J.; LUX, B. Identification of bacteria isolated from roots of sunflower (Helianthus annuus) cultivated in a French soil. Canadian Journal of Microbiology, v.37, p. 971-4, 1991.

FAGES, J.; MULARD, D. Isolement de bactéries rhizosphériques et effet de leur inoculation en pots chez Zea mays. Agronomie, v.8, p. 309-14, 1988.

FAHEY, J.W. Endophytic bacteria for the delivery of agrochemicals to plants. In: Cutler, H.O. ed. Biologically Active Natural Products. Potential Use In Agriculture. Washington, American Chemical Society Symposium Ser.380, 1988. p.120-8.

FANNIN, F.F.; BUSH, L.P.; SIEGEL, M.R.; ROWAN, D.D. Analysis of peramine in fungal endophyte - infected grasses by reversed-phase thin-layer chromatography. Journal of Chromatography, v.503, p. 288-92, 1990.

FISHER, P.J.; PETRINI, O.; LAPPIN SCOTT, H.M. The distribution of some fungal and bacterial endophytes in maize (Zea mays L.). New Phytologist, v.122, p. 299-305, 1992.

FOSTER, J.L.M.; FOGLEMAN, J.C. Identification and ecology of bacterial communities associated with necroses of three cactus species. Applied and Environmental Microbiology, v.59, p. 1-6, 1993.

FUTUYMA, D.J. Biologia Evolutiva. Ribeirão Preto: Sociedade Brasileira de Genética, 1993. 631p. 
GLIENKE, C. Variabilidade genética no fungo endófito Guignardia citricarpa Kieli detectada por RAPD. Curitiba, 1995, 115p. Dissertação. (Mestrado) Universidade Federal do Paraná.

HARRISON, S.P.; MYRTON,L.R.; SKØT, L.; DYE, M. CRESSWELL, A. Characterization of Rhizobium isolates by amplification of DNA polymorphisms using random primers. Canadian Journal of Microbiology, v.38, p. 1009-15, 1992.

HOLT, J.G.; KRIEG, N.R.; SNEATH, P.H.A.; STALEY, J.T.; WILLIAMS, S.T. BERGEY'S Manual of Determinative Bacteriology. Baltimore: Williams \& Wilkins, 1994. 787p.

JACOBS, M.J.; BUGBEE, W.M.; GABRIELSON, D.A.. Enumeration, location, and characterization of endophytic bacteria within sugar beet roots. Canadian Journal of Botany, v.63, p. 1262-5, 1985.

KÜSTER, E.; WILLIAMS, S.T. Selection of media for isolation of streptomycetes. Nature, v.202, p. 928-9, 1964.

LALANDE, R.; BISSONNETTE, N.; COUTLÉE, D.; ANTOUN, H. Identification of rhizobacteria from maize and determination of their plantgrowth promoting potential. Plant \& Soil, v.115, p. 7-11, 1989.

LIAO, C.H.; CHEN, T.A. Isolation, culture and pathogenicity to sudangrass of a corynebacteium associated with ratoon stunting of sugarcane and with bermudagrass. Phytopathology, v.71, p. 1303-6, 1981.

MacFADDIN, J.F. Pruebas bioquimicas para la identificacion de bacterias de importancia clinica. Buenos Aires: Editorial Médica Panamericana S.A., 1980. 301p.

MANIATS, T.; FRITSCH, E.F.; SAMBROOK, J. Molecular cloning: a laboratory manual. New York: Cold Spring Harbor laboratory, 1989. 545p. 
MARTIN, G.B.; WILLIAMS, J.G.K.; TANKSLEY, S.D. Rapid identification of markers linked to a Pseudomonas resistance gene in tomato by using random primers and near-isogenic lines. Proceedings of National Academy of Science USA, v.88, p. 2336- 40, 1991.

MARTIN-KEARLEY, J.; GOW, J.A.; PÉLOQUIN, M.; GREER, C.W. Numerical analysis and the application of random amplified polymorphic DNA polymerase chain reaction to the differentiation of Vibrio strains from a seasonally cold ocean. Canadian Journal of Microbiology, v.40, p. 446-55, 1994.

McINROY, J.A.; KLOEPPER, J.W. Analysis of population densities and identification of endophytic bacteria of maize and cotton in the field. Bulletin SROP., v. 14, p. 328-31, 1991.

MISAGHI, I.J.; DONNDELINGER, C.R. Endophytic bacteria in symptom-free cotton plants. Phytopathology, v.80, p. 808-11, 1990.

MURRAY, F.R.; LATCH, G.C.M.; SCOTT, D.B. Surrogate transformation of perennial ryegrass, Lolium perene, using genetically modified Acremonium endophyte. Molecular General Genetics, v.233, p. 1-9, 1992.

NAMBIAR, P.T.C.; MA, S.-W.; IYER,V.N. Limiting an insect infestation of nitrogen-fixing root nodules of the Pigeon Pea (Cajanus cajan) by engeenering the expression of an entomocidal gene in its root nodules. Applied and Environmental Microbiology, v.56, p. 2866-69, 1990.

NASPOLINI FILHO, V.; GAMA, E.E.G.; VIANNA, R.T.; MÔRO, J.R. General and specific combining ability for yield in a diallel cross among 18 maize populations (Zea mays L.). Revista Brasileira de Genética, v.4, p. 571-7, 1981.

PAMPHILE, J.A.; VIEIRA, M.L.C.; AZEVEDO, J.L. Isolamento e caracterização molecular por RAPD de linhagens endofíticas de Fusarium sp. isoladas de milho. In: REUNIÃO ANUAL DE GENÉTICA DE MICRORGANISMOS, 20, Piracicaba, 1995. Resumos. Piracicaba: 
BANDEL， G.; PIZZIRANI-KLEINER, A.A.; AZEVEDO, J.L. eds./SBG/USP/ESALQ, 1995, p. 122.

PEREIRA, J.O. Fungos endofiticos dos hospedeiros tropicais Stylosanthes guianensis e Musa cavendish. Piracicaba, 1993. 105p. Tese (Doutorado) Escola Superior de Agricultura "Luiz de Queiroz", Universidade de São Paulo.

PEREIRA, J.O.; AZEVEDO, J.L.; PETRINI, O. Endophytic fungi of Stylosanthes: a first report. Mycologia, v.85, p.362-4, 1993.

PETRINI, O. Fungal endophyte of tree leaves. In: ANDREWS,J. \& HIRANO,S.S., ed. Microbial ecology of leaves. New York: Spring Verlag, 1991. p.179-97.

POON, E.S.; HUANG, T.C.; KUO, T.T. Possible mechanism of symptom inhibition of bacterial blight of rice by an endophytic bacterium isolated from rice. Botanical Bulletin of Academia Sinica, v.18, p. 61-70, 1977.

QUISPEL, A. Bacteria-plant interactions in symbiotic nitrogen fixation. Physiologia Plantarum, v.74, p. 783-90, 1988.

READER, U.; BRODA, P. Rapid preparation of DNA from filamentous fungi. Letters in Applied Microbiology, v.1, p. 17-20, 1985.

REDDY, M.S.; HYNES, R.K.; LAZAROVITS, G. Relationship between in vitro growth inhibition of pathogens and supression of preemergence damping-off and postemergence root rot of white bean seedlings in the greenhouse by bacteria. Canadian Journal of Microbiology, v.40, p. 113-9, 1993.

RIBEIRO, L.A.. Variabilidade genética detectada por RAPD em fungos endófitos do gênero Penicillium provenientes de Zea mays. Curitiba, 1995, 74p. Dissertação. (Mestrado) - Universidade Federal do Paraná.

ROHLF, F.J. NTSYS-PC Numerical taxonomy and multivariate analysis system. New York: Exeter Publishing, 1988. 
SARDI, P.; SARACCHI, M.; QUARONI, S.; PETROLINI, B., BORGONOVI, G.E.; MERLI, S. Isolation of endophytic Streptomyces strains from surfacesterilized roots. Applied and Environmental Microbiology, v.58, p. 2691-3, 1992.

SIEBER, T.; RIESEN, T.K.; MÜLLER, E.; FRIED, P.M. Endophytic fungiin four winter wheat cultivars (Triticum aestivum L.) differing in resistance against Stagonospora nodorum (Berck) Berck. Journal Phytopathology, v.122, p. 289-306, 1988.

SNEATH, P.H; SOKAL, R.R. Numerical taxonomy. San Francisco: W.H. Freeman and Company, 1973, 573p.

SOUZA JUNIOR, C.L.; SANTOS, M.X.; MAGNAVACA, R.; GAMA, E.E.G. Estimativas de parâmetros genéticos na interpopulação de milho BR-105 x BR106 e suas implicações no melhoramento. Pesquisa Agropecuária Brasileira, v.28, p. $473-9,1993$.

SILVA, A.C.; PEREIRA, J.O.; AZEVEDO, J.L. Obtenção de fungos endofiticos de milho (Zea mays) var. PIRANÃO. In: REUNIÃO ANUAL DE GENÉTICA DE MICRORGANISMOS, 18, São Paulo, 1992. Resumos. São Paulo: SBG/USP, 1992, p. 134.

STEPHAN, R.; SCHRAFT, H.; UNTERMANN, F. Characterization of Bacillus licheniformis with the RAPD technique (randomly amplified polymorphic DNA). Letters in Applied Microbiology, v.18, p. 260-3, 199.

STONE, J.K. Foliar endophytes of Pseudotsuga menziesli (Mirb.) Franco. Cytology and physiology of the host-endophyte relationship. Eugene, 1986. 124p. (PhD-University of Oregon).

TESTER, C.F. Influence of a genetically modified endophytic bacterium on composition and decomposition of corn residue. Soil Biological and Biochemical, Britain, v.24, p. 1107-12, 1992. 
TURNER, J.T.; LAMPEL, J.S.; STEARMAN, R.S.; SUNDIN, G.W.; GUNYUZLU, P.; ANDERSON, J.J. Stability of the alfa-endotoxin gene from Bacillus thuringiensis subsp. Kurstaki in a recombinant strain of Clavibacter xyli subsp. cynodontis. Applied and Environmental Microbiology, v.57, p. 3522-28, 1991.

VÖLKSCH, B.; ULLRICH, M.; FRITSCH, W. Identification and population dynamics of bacteria in leaf spots of soybean. Microbial Ecology, v.24, p. 305-11, 1992.

WANG, G.; WHITTAM, T.S.; BERG, C.M.; BERG, D.E. RAPD (Arbitrary primer) PCR is more sensitive than multilocus enzyme electrophoresis for distinguishing related bacterial strains. Nucleic Acid Research, v.21, p. 59303, 1993.

WEBER, A.; SARSA, M.-L; SUNDMAN, V. Frankia-Alnus incana symbiosis: effect of endophyte on nitrogen fixation and biomass production. Plant and Soil, v.120, p. 291-7, 1989.

WHITESIDES, S.K.; SPOTTS, R.A. Frequency, distribution, and characteristics of endophytic Pseudomonas syringae in pear trees. Phytopathology, v.81, p. 453-7, 1991.

WILLIAMS, J.G.K.; HANAFEY, M.K.; RAFALSKI, J.A. Genetic analysis using random amplified polymorfic DNA markers. Methods in Enzymology, v.218, p. 704-40, 1993.

WILLIAMS, J.G.K.; KUBELIK, A.R. LIVAK,K.J. DNA polymorphisms amplified by arbitrary primers are useful as genetic markers. Nucleic Acid Research, v.18, p. 6531-5, 1990. 